Linköping University Medical Dissertations No. 1493

\title{
APPLICATIONS OF HUMAN SKIN IN VITRO
}

\author{
Susanna Lönnqvist
}

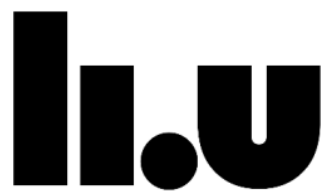

LINKÖPING UNIVERSITY

Division of Clinical Sciences

Department of Clinical and Experimental Medicine Medical Faculty

Linköping, 2016 
(C) Susanna Lönnqvist, 2016

ISBN: 978-91-7685-895-0

ISSN: 0345-0082

Papers III and IV are reprinted with the permission of Taylor \& Francis

During the course of the research underlying this thesis, the author was enrolled in Forum Scientium, a multidisciplinary doctoral programme at Linköping University, Sweden.

Printed by LiU-Tryck, Linköping, Sweden December 2015 
Siis älä siitä huoli, näinhän täällä käy Aurinkokin paistaa, vaikkei sitä näy (Eppu Normaali, 1993)

So don't you worry about it, that's the way things go The sun is still shining, even though it doesn't show 


\section{SUPERVISOR}

Gunnar Kratz, Professor

Department of Clinical and Experimental Medicine Linköping University

\section{CO-SUPERVISOR}

Magnus Berggren, Professor

Department of Science and Technology

Linköping University

\section{FACULTY OPPONENT}

Jyrki Vuola, Associate Professor

Institute of Clinical Medicine

Helsinki University 
Chronic wounds are a substantial problem in today's health care and place significant strains on the patient. Successful modelling of the wound healing process is pivotal for the advancement of wound treatment research. Wound healing is a dynamic and multifactorial process involving all constituents of the skin. The progression from haemostasis and inflammation to proliferation of epidermal keratinocytes and dermal fibroblasts, and final scar maturation can be halted and result in a chronic wound that fails to re-epithelialise. The wound healing process constitutes an example of dynamic reciprocity in tissue where cellular changes take place on cues from the extracellular matrix and vice versa when tissue homeostasis is disturbed. The extracellular matrix provides a structural context for the resident cells and the epidermal keratinocytes, and a functioning interplay between the two tissue compartments is crucial for successful wound healing to take place. Work included in this thesis has applied viable human full thickness skin in vitro to investigate the re-epithelialisation process and barrier function of intact skin. The use of full thickness skin in vitro can take into account the contextual aspect of the process where the epidermal keratinocytes are activated and obtain a migratory phenotype, and are continuously dependent on the cues from the extracellular matrix and support of the dermis. When utilising skin for studies on re-epithelialisation, circular standardised full thickness wounds were created and cultured for up to four weeks in tissue culture. In paper I, the organisation of a thick neoepidermis was investigated in the in vitro wound healing model when resident cells were provided with a porous suspended three dimensional gelatin scaffold. In paper II we investigated the use of a fluorescent staining conventionally used for proliferation studies to facilitate the tracing of transplanted epidermal cells in in vitro wounds, in order to improve and expand the use of the model. In paper III the model was utilised to investigate the treatment approach of acidification of wounds to evaluate the suitability of such intervention 
in regards to keratinocyte function and re-epithelialisation. Studies on reepithelialisation with the aid of the in vitro wound healing model provided insight in neoepidermal structure with porous gelatin scaffolding in the wound, a novel methodological approach to tracing cells and response to constrained wound healing environment. In paper IV, intact human skin was evaluated for modelling the cytotoxic response after exposure to a known irritant compound. To study barrier function, intact skin was exposed to irritants by restricting exposure topically, and full thickness skin in vitro was found suitable for modelling cytotoxicity responses. Employing human full thickness skin in vitro makes use of the actual target tissue of interest with epidermal and dermal cells, and full barrier function. 


\section{Populärvetenskaplig sammanfattning}

Då huden skadas och ett sår bildas startas en mängd processer för att hejda ytterligare skada, begränsa infektion och reparera vävnaden för att återskapa den starka barriär som huden bildar mot omvärlden. Sårläkning är en dynamisk process som involverar alla celler och komponenter i huden. Läkningen startar med att blodflödet stillas och ett inflammatoriskt svar tar vid för att rengöra det skadade området. Cellerna i sårets kanter och i underliggande vävnad aktiveras för att reparera skadan. Översta hudlagret, epidermis, består av flera lager av epidermala keratinocyter. Denna celltyp ser till att den strukturella barriären som huden utgör är intakt genom att det $\mathrm{i}$ nedersta lagret av epidermis hela tiden bildas nya keratinocyter. Dessa genomgår sedan en process som till slut bildar ett flerskikat lager av keratinocyter med döda och tåliga keratinocyter allra ytterst. Vid uppkomsten av ett sår aktiveras keratinocyterna och får egenskaper de annars inte uppvisar. De blir mobila då deras mål är att flytta sig ut från sårkanterna, bli flera och till slut täcka över såret med keratinocyter och slutligen ny epidermis. Samtidigt som keratinocyterna täcker in såret jobbar cellerna i det undre hudlagret dermis med att utsöndra komponenter för att möjliggöra keratinocyternas vandring ut från sårkanterna. Dessa celler heter dermala fibroblaster, och de fortsätter med att utsöndra beståndsdelar för den nya vävnaden och bidrar till att bilda de delar som till slut blir ett ärr i huden. De epidermala keratinocyterna och de dermala fibroblasterna är beroende av varandra i sårläkningsprocessen, och de signallerar till varandra och omgivande vävnad under hela förloppet.

Avhandlingens arbeten har riktat in sig på att undersöka hur man kan använda mänsklig hud i laboratoriet för att undersöka sårläkningsprocessen och barriärfunktionen hos hud. Genom att använda sig av hud $i$ en laboratorieuppställning kan man studera händelseförloppet och delar av det genom att ändra vissa detaljer, införa behandling eller ändra miljön som huden och 
cellerna i den hålls i. Användning av mänsklig hud möjliggör iakttagandet av samarbetet mellan keratinocyterna och fibroblasterna, och de olika delarna av huden de finns i, vilket inte är möjligt i förenklade modeller av hud. Att hitta bra och representativa sätt att följa sårläkning är viktigt för att hitta mekanismer vid bildning av sår som inte läker och behandling av dem. 


\section{Populaaritieteellinen tiivistelmä}

Kun iho vahingoittuu ja syntyy haava, käynnistyy samanaikaisesti useita eri prosesseja haavan parantamiseksi: lisävaurioita pitää välttää, infektioriskiä pienentää ja fyysinen suoja pitää luoda uudestaan. Haavan parantuminen on dynaaminen prosessi johon osallistuvat kaikki ihon eri solutyypit ja osat. Parantuminen alkaa verenvuodon pysähtymisellä ja tulehdusvasteella, jotta vaurioitunut kudos pysyy puhtaana. Ihosolut haavan reunoissa ja alla olevassa kudoksessa aktivoituvat. Ihon ylin kerros, orvaskesi, koostuu keratinosyyteistä. Tämä solutyyppi pitää huolen ihon rakenteellisesta suojasta siten, että orvaskeden alimmassa kerroksessa syntyy jatkuvasti uusia keratinosyyttejä. Nämä solut käyvät läpi eri kehitysmuotoja, jotka johtavat kerroksittaiseen orvaskeden rakenteeseen, ja muodostavat lopuksi orvaskeden ylimmän kerrokseen, jonka solut ovat kuolleita ja hyvin kestäviä. Kun iho vahingoittuu, keratinosyytit aktivoituvat ja ryhtyvät toimimaan normaalista poikkeavalla tavalla. Keratinosyytit muutuvat liikkuviksi ja niiden tavoitteena on siirtyä haavan reunasta peittämään haavaaluetta. Keratinosyyttejä syntyy lisää ja lopulta koko haavan alue on niiden peitossa ja uuden orvaskeden muodostuminen voi alkaa. Samaan aikaan kun keratinosyytit vaeltavat haavojen reunoilta poispäin, solut alla olevassa haavakudoksessa tuottavat kudososia jotka mahdollistavat tämän vaelluksen. Nämä solut ovat fibroblasteja, sidekudoksessa yleisesti esiintyvää solutyyppiä. Fibroblastit jatkavat uuden sidekudoksen osien tuottamisen ja avustavat niiden osien kanssa, jotka lopulta muodostavat arven ihossa. Keratinosyytit ja fibroblastit ovar riippuvaisia toisistaan koko haavan parantumisen keston ajan ja kommunikoivat toistensa kanssa prosessin kuluessa.

Tässä väitöskirjassa keskitytään tutkimaan miten ihmisihoa voi käyttää laboratoriossa jotta haavan parantumista ja ihon suojan muodostamista voitaisiin tutkia. Ihon käyttö laboratoriossa mahdollistaa haavan parantumisen eri vaiheiden 
tutkimisen, koska prosessin eri osia voi silloin muunnella tai niihin voi vaikuttaa hallitusti. Ihon käyttö mahdollistaa myös keratinosyyttien ja fibroblastien yhteistyön tutkimisen, mikä ei ole mahdollista yksinkertaisemmissa iho-malleissa. Hyvien ja edustavien mallintamismuotojen löytyminen on tärkeää kroonisten haavojen ja niiden hoitomuotojen tutkimisessa. 


\section{Table of contents}

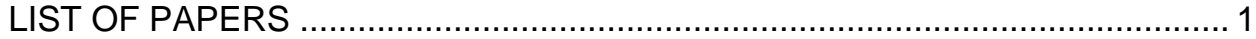

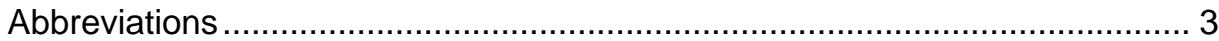

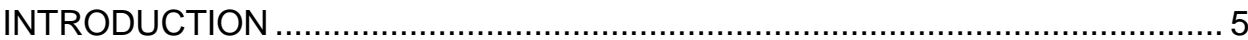

The structure of the epidermis is linked to the life cycle of the keratinocyte ..... 5

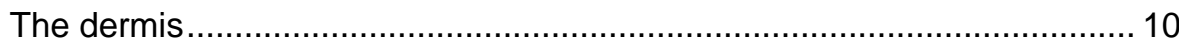

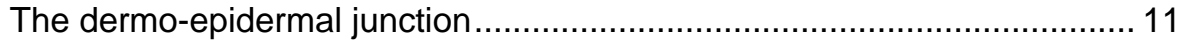

When the barrier is breached .............................................................. 13

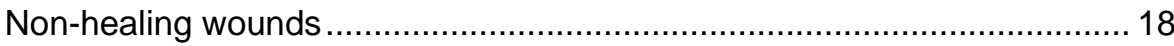

Wound treatment - dressings, skin substitutes and scaffolds ....................... 20

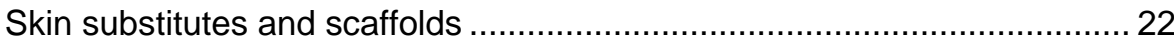

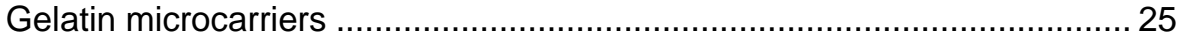

Modelling skin and wound healing....................................................... 26

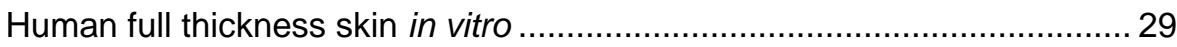

Skin, wound healing and reciprocity ........................................................ 31

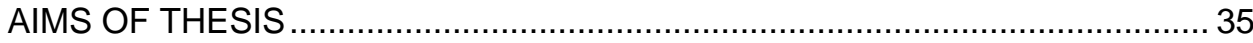

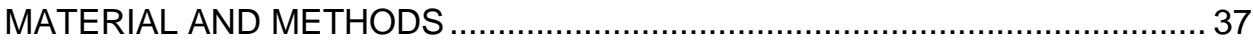

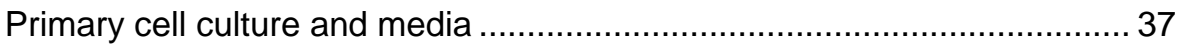

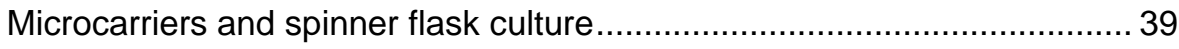

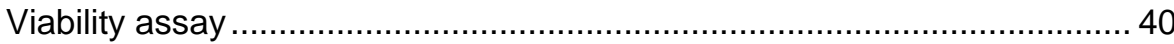

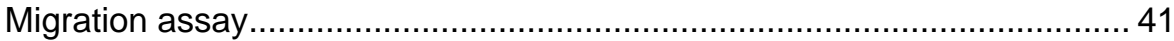

Quantitative real-time polymerase chain reaction .................................... 42

Human in vitro wound healing model ................................................... 43

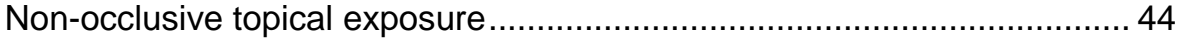

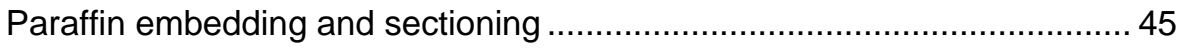

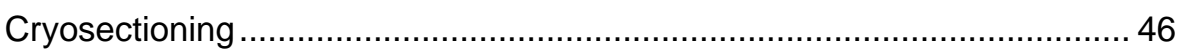

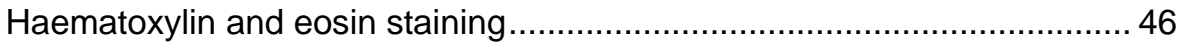

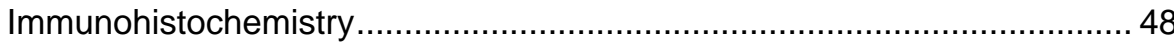

Carboxyfluorescein hydroxysuccinimidyl ester (CFSE) staining ................ 49

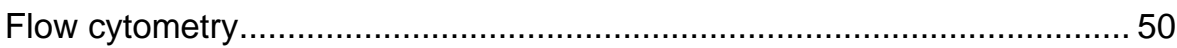

Fluorescence microscopy and confocal microscopy ................................. 51 


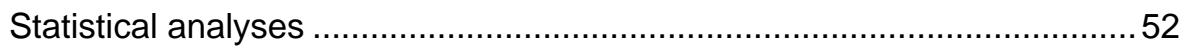

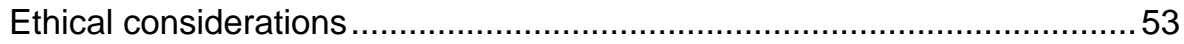

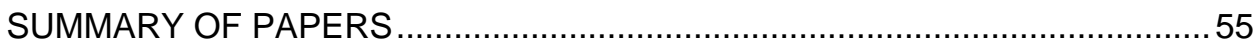

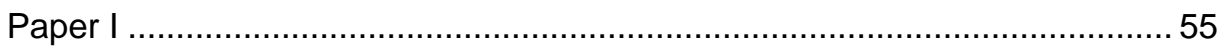

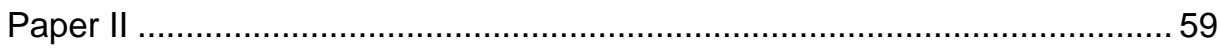

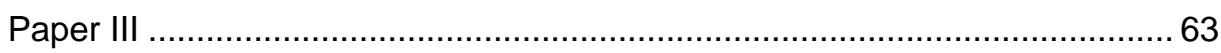

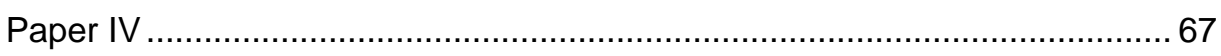

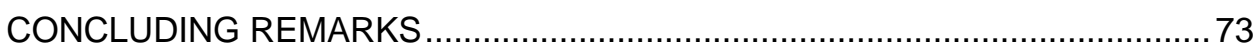

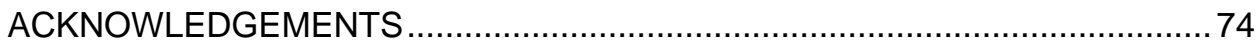

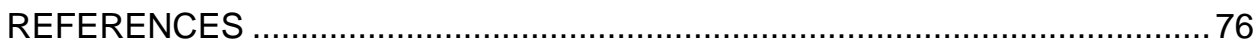




\section{LIST OF PAPERS}

This thesis is based on the following papers, which are referred to in the text by their Roman numerals:

\section{Paper I}

Susanna Lönnqvist, Jonathan Rakar, Kristina Briheim, Gunnar Kratz

Biodegradable gelatin microcarriers facilitate re-epithelialization of human cutaneous wounds - an in vitro study in human skin

PLoS One 2015 Jun 10;10(6)

\section{Paper II}

Susanna Lönnqvist, Maria Karlsson, Gunnar Kratz

Tracing transplanted human keratinocytes and melanocytes with carboxyfluorescein hydroxysuccinimidyl ester (CFSE) staining Manuscript

\section{Paper III}

Susanna Lönnqvist, Peter Emanuelsson, Gunnar Kratz

Influence of acidic $\mathrm{pH}$ on keratinocyte function and re-epithelialisation of human in vitro wounds

Journal of Plastic Surgery and Hand Surgery 2015 Jun 7:1-7

\section{Paper IV}

Susanna Lönnqvist, Kristina Briheim, Gunnar Kratz

Non-occlusive topical exposure of human skin in vitro as model for cytotoxicity testing of irritant compounds

Toxicology Mechanisms and Methods 2015 Oct 8:1-6 
Publication by the author not included in the thesis:

Kristin M. Persson, Susanna Lönnqvist, Klas Tyrbrandt, Roger Gabrielsson, David Nilsson, Gunnar Kratz, Magnus Berggren

Matrix-Addressing of an Electronic Surface Switch Based on a Conjugated Polyelectrolyte for Cell Sorting

Advanced Functional Materials 2015 Oct 21

Johan Junker, Susanna Lönnqvist, Jonathan Rakar, Lisa Karlsson, Magnus Grenegård, Gunnar Kratz

Differentiation of human dermal fibroblasts towards endothelial cells Differentiation 2013 Feb;85(3):67-77

Jonathan Rakar, Susanna Lönnqvist, Pehr Sommar, Johan Junker, Gunnar Kratz Interpreted gene expression of human dermal fibroblasts after adipo-, chondro-, and osteogenic phenotype shifts

Differentiation 2012 Nov;84(4):305-13 


\section{Abbreviations}

\begin{tabular}{|c|c|}
\hline$\alpha$-SMA & $\alpha$-smooth muscle actin \\
\hline ANOVA & analysis of variance \\
\hline bFGF & basic fibroblast growth factor \\
\hline BPE & bovine pituitary extract \\
\hline BSA & bovine serum albumin \\
\hline $\mathrm{Ca}^{2+}$ & calcium cation \\
\hline cDNA & complementary deoxyribonucleic acid \\
\hline CFSE & carboxyfluorescein hydroxysuccinimidyl ester \\
\hline CLDN1 & claudin 1 \\
\hline $\mathrm{COL}$ & collagen \\
\hline $\mathrm{Ct}$ & cycle threshold \\
\hline DAPI & 4', 6-diamino-2-phenylindole \\
\hline dbcAMP & $\mathrm{N}^{6}, 2^{\prime}$-O-Dibutyryladenosine $3^{\prime}, 5^{\prime}$-cyclic monophosphate \\
\hline DMEM & Dulbecco's Modified Eagle Medium \\
\hline DMSO & dimethyl sulfoxide \\
\hline DNA & deoxyribonucleic acid \\
\hline ECM & extracellular matrix \\
\hline ECVAM & European centre for validation of alternative methods \\
\hline EDC & epidermal differentiation complex \\
\hline EDTA & ethylenediamine tetra acetic acid \\
\hline EGF & epidermal growth factor \\
\hline FAK & focal adhesion kinase \\
\hline FCS & foetal calf serum \\
\hline FM & fibroblast medium \\
\hline GM-CSF & granulocyte-macrophage colony stimulating factor \\
\hline $\mathrm{H} \& \mathrm{E}$ & haematoxylin and eosin staining \\
\hline HMBS & hydroxymethylbilane synthase \\
\hline HSP27 & heat shock protein 27 \\
\hline HSPB1 & heat shock $27 \mathrm{kDa}$ protein 1 \\
\hline ICAM-1 & intercellular adhesion molecule 1 \\
\hline IFN- y & interferon $\mathrm{y}$ \\
\hline IL & interleukin \\
\hline KER & keratinocyte \\
\hline KGF & keratinocyte growth factor \\
\hline Ki-67 & nuclear antigen Ki-67 \\
\hline
\end{tabular}




$\begin{array}{ll}\text { KLK } & \text { kallikrein-related peptidase } \\ \text { KRT } & \text { keratin } \\ \text { KSFM } & \text { keratinocyte serum free medium } \\ \text { MEL } & \text { melanocyte } \\ \text { MGM } & \text { melanocyte growth medium } \\ \text { MHC } & \text { major histocompatibility complex } \\ \text { MMP } & \text { matrix metalloproteinase } \\ \text { mRNA } & \text { messenger ribonucleic acid } \\ \text { MTT } & \text { 3-(4, 5-dimethyl-thiazol-2-yl)-2, 5-diphenyl tetrazolium bromide } \\ \text { OCT } & \text { optimal cutting temperature compound } \\ \text { PBS } & \text { phosphate buffered saline } \\ \text { PC-1 } & \text { PC-1 }{ }^{\text {TM }} \text { supplement } \\ \text { PCL } & \text { polycaprolactone } \\ \text { PDGF } & \text { platelet derived growth factor } \\ \text { PFA } & \text { paraformaldehyde } \\ \text { PGA } & \text { polyglycolic acid } \\ \text { PLA } & \text { polylactic acid } \\ \text { PTK2 } & \text { protein tyrosine kinase 2 } \\ \text { qRT-PCR } & \text { quantitative real time polymerase chain reaction } \\ \text { RGD } & \text { arginine-glycine-aspartate tripeptide } \\ \text { RMP } & \text { revolutions per minute } \\ \text { RNA } & \text { ribonucleic acid } \\ \text { S100A } & \text { S100 calcium binding protein A family } \\ \text { SDS } & \text { sodium dodecyl sulphate } \\ \text { TGF- } \alpha & \text { transforming growth factor } \alpha \\ \text { TGF- } \beta & \text { transforming growth factor } \beta \\ \text { TIMP1 } & \text { tissue inhibitor of matrix metalloproteinase 1 } \\ \text { TNF- } \alpha & \text { tumour necrosis factor } \alpha \\ \text { UV } & \text { ultraviolet } \\ \text { VEGF } & \text { vascular endothelial growth factor } \\ \text { ZO-1 } & \text { zona occludens 1 } \\ & \end{array}$




\section{INTRODUCTION}

The skin constitutes a physical and molecular barrier against dehydration, pathogens and toxins. Stratum corneum, the outermost layer of the skin, forms a lipophilic barrier and together with a band of tight junctions and the innate immune system, comprise the first line of defence against the strains of the outside world. The layered structure compartmentalises the functions of the skin. The uppermost layer, the epidermis, forms the first line of barrier. The dermis underneath provides mechanical strength and possesses barrier, sensory and immune functions. The hypodermis forms the structural integrity of the tissue and provides vascularisation (Figure 1).

\section{The structure of the epidermis is linked to the life cycle of the keratinocyte}

The epidermis is a keratinised stratified squamous epithelium composed predominantly of keratinocytes as well as melanocytes, Langerhans' cells and Merkel cells. The epidermis consists of four layers: stratum basale with proliferative keratinocytes, stratum spinosum, stratum granulosum, and the stratum corneum (1). An additional layer between granulosum and corneum called stratum lucidum is present in areas of skin highly subjected to friction such as the palms and soles (2). The keratinocytes of the epidermis stem from epidermal stem cells which are present in the stratum basale. By dividing they give rise to the transit amplifying cell compartment that ultimately undergoes terminal differentiation and cell death to form the stratum corneum of densely packed cell membranes of keratinocytes (3). Keratinocytes express specific sets of keratins during their passage through the epidermis. Keratins are elastic fibrous proteins that form cytoplasmic intermediate filaments and are expressed in heterodimeric pairs with one acidic (type I) and one basic (type II) keratin (4). Basal keratinocytes express keratin 5 (type II) and keratin 14 (type I), and differentiating keratinocytes 
express keratin 1, 2 (type II), and 10 (type I) (5). The keratin filament network anchors keratinocytes to the basement membrane through hemidesmosomes in stratum basale (6) and to adjacent keratinocytes through desmosomes, intercellular junction complexes associated with intermediate filaments (7), in all layers of epidermis (8). The stratum granulosum (Figure 1) consists of three layers of cells and is characterised by the presence of keratohyalin granules consisting of keratin binding proteins, such as filaggrin and loricrin. Together with mainly keratin 1 and 10, the proteins form a dense network of keratin filaments bundles (1). A strand of tight junctions is present in the second layer of cells in the stratum granulosum. This structure can be found on the apical side of most sheets of simple epithelium in vertebrates and functions as a sealing to control the paracellular pathways (9) for ions, small molecules and water (10). In the epidermis the cellcell junctions consist of different transmembrane proteins like claudins (11) and cytosolic plaque proteins like zona occludens ( $\mathrm{ZO}$ ) proteins, out of which claudin 1 (CLDN1) has been shown to contribute strongly to the integrity of the junctional complexes (10). Knock-out mice for CLDN1 die within the first day after birth due to transepithelial water loss (12). The stratum granulosum is a transitional zone of the epidermis where the separation of metabolically active layers and the dead stratum corneum takes place.

The stratification of the epidermis is tightly connected to the life cycle of the keratinocyte. The keratinocytes of the uppermost layer of the stratum granulosum undergo terminal differentiation and a form of programmed cell death called cornification. The end product is the formation of the stratum corneum composed of 10-20 layers of enucleated cells forming a supracellular interconnected structure consisting of corneocytes (13). The formation of the stratum corneum takes place in three major steps: the replacement of intracellular contents of the keratinocytes by a proteinaceous cytoskeleton, the formation of the cornified envelope and the secretion of extracellular lipids. At the transition zone of the stratum granulosum 


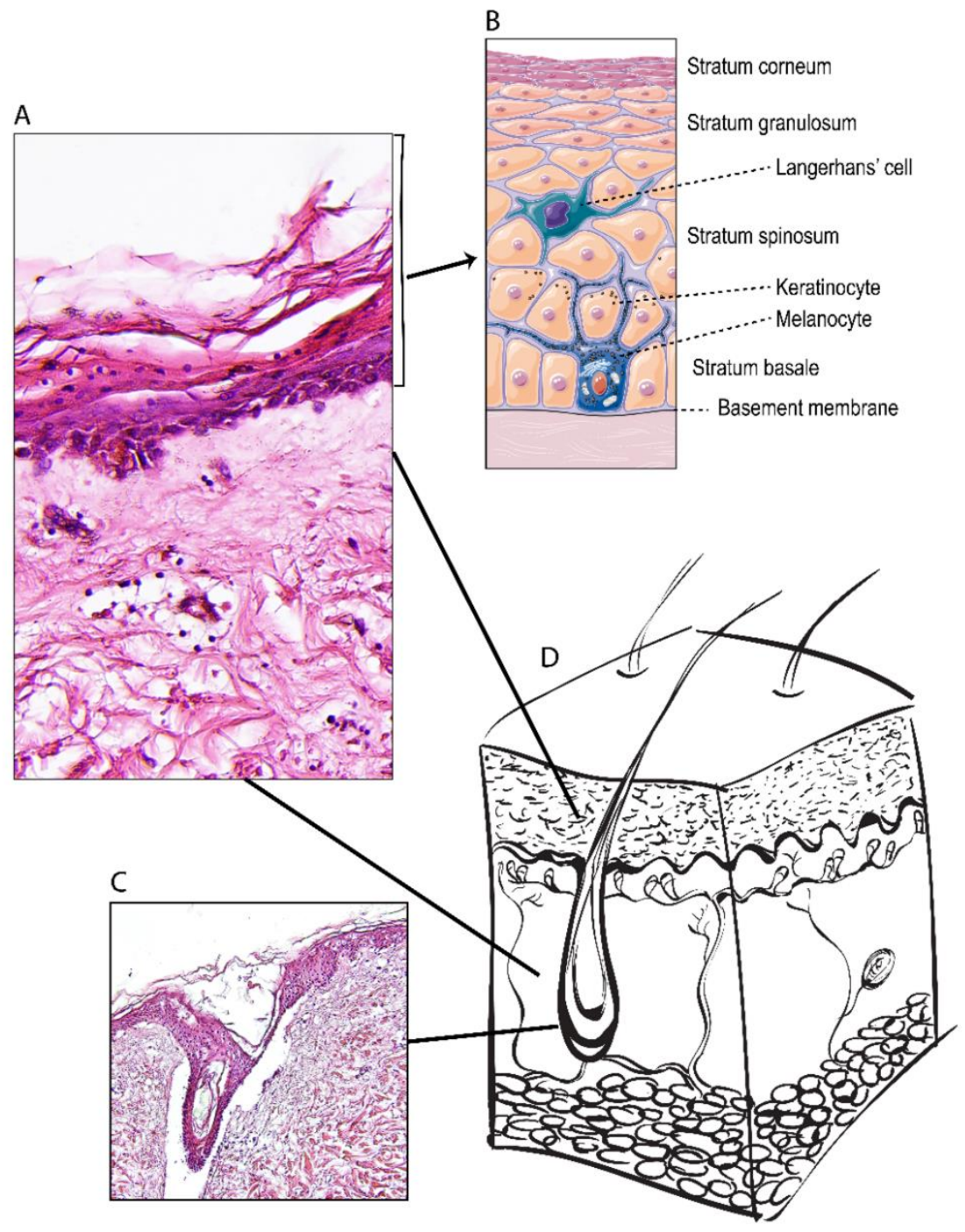

Figure 1. (A) Haematoxylin and eosin (H\&E) staining of human skin with stratified, cornified epidermis and papillary and reticular dermis. (B) Schematic representation of the layers and cells of the epidermis. (C) H\&E staining of hair follicle. (D) Schematic drawing of human skin with superficial epidermis, dermis with hair follicle and vessels, and subcutaneous fat of the hypodermis. Images captured or drawn by author, except (B) based on Servier Medical Art (licensed under Creative Commons). 
keratinocytes undergo enucleation and morphologically change into flat polygonal cells. The organelles and the keratohyalin granules are degraded. The mechanisms of nuclear degradation and the following disassembly of the organelles are not well understood (14). The dephosphorylation of profilaggrin has been proposed as an initiating step in disassembling the keratin and keratin binding proteins $(1,15)$. The transition from residing in the stratum granulosum to partake in the formation of the stratum corneum, is initiated by an increase in intracellular $\mathrm{Ca}^{2+}(16)$, which has been shown to induce in vitro differentiation of keratinocytes as well (17). In addition, caspase 14 is involved in the process and is activated in the granular layer and contributes to the degradation of filaggrin (15). The keratinocytes form cornified envelopes where the plasma membranes are replaced by protein products of the epidermal differentiation complex (EDC) genes that are highly crosslinked by calcium activated transglutaminases specifically expressed in the cornifying layers (18). The EDC locus on chromosome 1q21 contains genes like loricrin, involucrin and the S100A family, and their expression is used as late maturation markers of the epidermis. The dense assembly of the transglutaminase crosslinked proteins is essential for the barrier function of the skin (19). The final stages of the life cycle of granular keratinocytes include the formation of the cornified envelope and the secretion of the lamellar granules, membrane bound cytoplasmic organelles found in stratum spinosum and granulosum. The lamellar granules, or lamellar bodies, fuse with the plasma membrane and thereby contribute to the hydration of the epidermis by secreting their contents into the extracellular space. The ceramides, free fatty acids and cholesterol of the lamellar granules seal the superficial granular layers and are responsible for the hydrophobic barrier of the epidermis (20).

The cornified keratinocytes of the stratum corneum are joined together through corneodesmosomes, an adhesion complex similar to the desmosome, but characterised by the presence of a unique extracellular component known as 
corneodesmosin (21). Produced by keratinocytes and secreted by granular keratinocytes through the lamellar granule pathway, it is localised in the extracellular structures of the corneodesmosomes and cross-linked to the cornified cell envelopes (20). Corneodesmosin is gradually proteolysed under transition in the stratum corneum and ultimately cleaved by kallikrein-related peptidases (KLKs) and cathepsins (22). This leads to the desquamation of the epidermal keratinocyte, the final step in the keratinocyte's role as the structural component of the barrier of the epidermis (23).

Other cell types in the epidermis include the pigment producing melanocytes, Langerhans' cells and Merkel cells. Melanocytes are located in the stratum basale (24) and make up approximately $5 \%$ of the cells of the epidermis (25). One epidermal-melanin unit consists of one dendritic melanocyte and an average of 36 keratinocytes (26). Once formed, melanin containing granules, called melanosomes, are translocated to the dendritic tips of the melanocytes by active transport (27). The melanosomes are transferred to keratinocytes by shedding vesicle transport and the melanosomes are trapped by microvilli on keratinocytes and incorporated into the cytosol. Once inside the cell, the melanosomes are dispersed with the ultimate goal to form a perinuclear cap in the keratinocytes to protect DNA from UV-light induced damage (28).

The only immune cells resident in the epidermis are the Langerhans' cells. As immature dendritic cells, they phagocytose actively in stratum spinosum. In the case of an injury and infection Langerhans' cells migrate to the peripheral lymph nodes, loose the antigen processing capabilities but upregulate major histocompatibility complex (MHC) and present antigens at a high level (29).

Merkel cells are mechanosensory cells located in the basal layer and form synapselike connections to somatosensory afferents in the dermis where they convey touch 
and pressure sensations (30). Merkel cells have been shown to be essential for the fine tuning of the pressure sensation which enables light touch discrimination of textures and edges (31).

\section{The dermis}

The connective tissue that constitutes the dermis is produced by dermal fibroblasts. Additional cell types present are macrophages and adipocytes. The dermis harbours nerves, glands, hair follicles and blood vessels that supply the skin and participate in thermal regulation. The most abundant proteins of the extracellular matrix (ECM) of connective tissues, and the whole human body, are collagens (32). By forming trimeric triplehelices that are organised into fibrils, the network formed by collagens has a high structural integrity that accounts for the toughness of skin. The fibril forming collagens I and III are present in the dermis. Basement membranes, and the stratum basale, contain collagen IV, which connects to collagens in the dermis via the anchoring fibril collagen VII (33). The elastic properties of the dermis are on account of the presence of micro fibrils of fibrillin with a core of cross-linked elastin. The elastic fibres provide compliance and recoil properties to the tissue and complements the collagen fibrils to form a resilient tissue construction (34). A dermal ECM protein with high importance for cell adhesion and migration is fibronectin $(35,36)$. The integrin binding RGD motif (arginine-glycine-aspartate tripeptide) was discovered in fibronectin. Fibronectin is an example of how ECM proteins can bind other ECM constituents, growth factors, receptors and adhesion proteins (37), and contribute to both structure and function of the ECM. Integrins are heterodimeric transmembrane receptors that can arrange into 24 different combinations and have high affinities for molecules in the ECM (38). The extrafibrillar matrix of the ECM beyond the fundamental structural proteins consists of glycosaminoglycans like hyaluronic acid, and proteoglycans. Proteoglycans contribute to the resistance to compression of the 
dermis by being highly hydrophilic due to the positively charged polysaccharide chains $(39,40)$.

The structural division of the dermis in two layers is based on the packing of the connective tissue. The most superficial part of the dermis, the papillary dermis, is characterised by areolar connective tissue organised in dermal papillae forming projections into the epidermal side. Tactile receptors, the Meissner corpuscles (41), and free nerve endings are present in the papillae that are responsible for the conduction of sensations of e.g. pain. Somatosensory afferents from the reticular dermis underneath connects to Merkel cells in the basal layer of the epidermis through Merkel discs located in conjunction with the basement membrane, forming Merkel cell-neurite complexes making up a direct contact between the two tissue compartments $(30,42)$. The reticular dermis is a dense network of collagens and coarse elastic fibres making up the bulk of the skin and providing for its integrity and extensibility. Interspersed in the spaces between the connective tissue bundles are adipocytes, glands, nerves and the hair follicles. Epidermal cells are present in two of the structures of the hair follicle: in the matrix surrounding the connective tissue papilla and in the bulge of the hair follicle (Figure 1). Keratinocytes and melanocytes are resident in the matrix of the hair follicle and the origin of the epithelial cells is the epidermal stem cells of the bulge of the hair follicle (43). The bulge cells only contribute to the structure of the epidermis in the case of re-epithelialisation of a wound where the cells respond quickly to damage but give rise to a transit amplifying population that later is replaced by strictly epidermal keratinocytes (44).

\section{The dermo-epidermal junction}

The epidermis and dermis are separated by a basement membrane (Figure 1) (45). The membrane forms the physical division between the tissue compartments, restricts molecular transport between them and dictates polarity of the basal 
keratinocytes which is of importance for the directionality of the differentiation and maturation of the epidermis (46). The dermo-epidermal junction is unique within basement membranes in its structure due to the presence of anchoring complexes. These structures establish integrin-mediated connections to link basal keratinocytes to the basement membrane. Integrin combinations expressed by basal keratinocytes are $\alpha 2 \beta 1, \alpha 3 \beta 1$, and $\alpha 6 \beta 4$, out of which $\alpha 4 \beta 6$ is strictly expressed on the basal side of the keratinocytes, opposing the basement membrane (47) and exclusively expressed in the hemidesmosomes in mature epidermis (48). The anchoring complex proteins are the link between the cytokeratin intermediate filaments of the basal keratinocytes and the basement membrane (Figure 2). The anchoring filaments are 2-4 nm in diameter and predominantly consist of laminin 5. Laminins are heterotrimeric basement membrane proteins composed of $\alpha, \beta$ and $\gamma$ chains. Two nomenclatures are used today: laminin 5 was the fifth trimer composition discovered, but new nomenclature names laminins after chain numbers rendering laminin 5 and laminin 322 the same protein (49). Laminin 5 connects the hemidesmosomes through integrin $\alpha 6 \beta 4$ to other laminins and collagen VII in the basement membrane compartment. Collagen VII in turn links the fibrous matrix elements (collagens I, III and V and fibrillins) and thereby anchors the complete complex to the papillary dermis. The anchoring complex

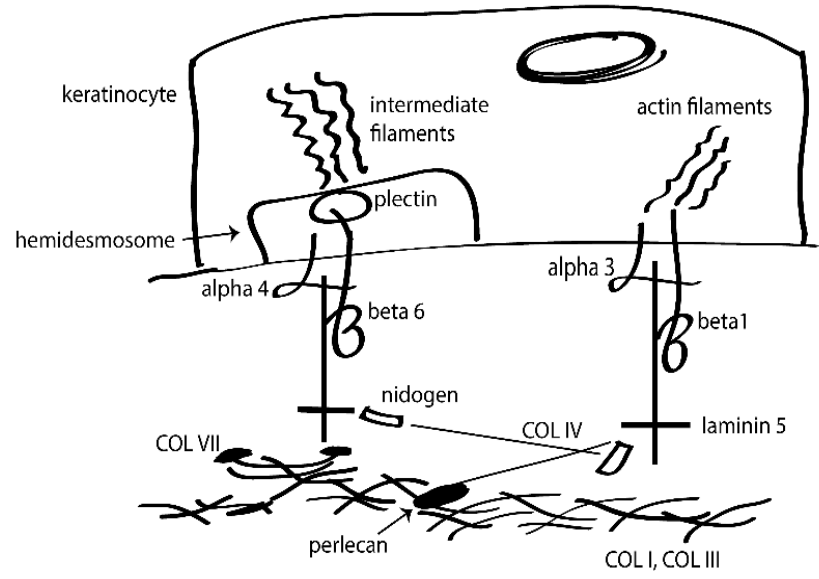

Figure 2. Organisation of the basement membrane with connections to the basal keratinocyte via integrins, and the collagens in papillary dermis. COL: collagen. Adapted from Uitto et al. $2001^{31}$ 
system provides the structural integrity needed for the frictional forces that skin is subjected to $(47,50)$.

\section{When the barrier is breached}

When wounding occurs, a myriad of processes are initiated to restore the barrier of the skin. Wound healing is a dynamic process involving all cell types in the skin, soluble factors and the ECM (51). A broad subdivision of the process is the inflammatory phase, proliferative phase and tissue remodelling phase (Figure 3).

The inflammatory phase is a direct response to the disruption of the tissue and the resident blood vessels. The blood clot formation achieves haemostasis and provides the cells in the wound with a provisional ECM. Platelets and injured cells start secreting mediators that recruit monocytes, fibroblasts and leukocytes to the site $(52,53)$. Infiltrating neutrophils remove debris and bacteria from the site and monocytes are recruited by ECM fragments and transforming growth factor $\beta$ (TGF- $\beta$ ). Once activated, the macrophages release platelet derived growth factor (PDGF) (54) and vascular endothelial growth factor (VEGF), essential for formation of the granulation tissue (55). Granulation tissue is the provisional ECM formed during the wound healing process by major rearrangement of the ECM and that will eventually form the novel stroma $(56,57)$. Other monocyte and macrophage derived growth factors in the early inflammatory stage of wound healing are TGF- $\alpha$, interleukin 1 (IL-1) and TGF- $\beta$ (58) (Figure 3 B).

Epidermal keratinocytes are presented with an alternative pathway to differentiation upon injury, the pathway of activation. The activation of keratinocytes to hyperproliferative and migratory cells (59) is affected by extracellular stimuli and signals, and characterised by differential expression of keratins. The activation of keratinocytes leads to proliferation, migration, upregulation of cell surface receptors and production of basal membrane 
components, all important for the re-epithelialisation process. Re-epithelialisation commences within hours of injury $(58,60,61)$. Activated keratinocytes express keratins 6,16 and $17(5,62)$. The accumulation of keratin 6 and 16 in wound edge keratinocytes coincides with the rearrangement of keratin 5 and 14 filaments changing from pancytoplasmic to concentrated at the edge of the cell, directed away from the migrational leading edge. The major cytoarchitectural changes precede the migration of keratinocytes out into the wound bed which also requires changes in the structure and number of desmosomes (63). The initiation of reepithelialisation also requires downregulation of hemidesmosomal links between the epidermis and the basement membrane to allow lateral movement of activated keratinocytes $(58,64)$.

Epidermal keratinocytes are on constant stand-by for responding to attacks on the barrier. Sequestered in the cytoplasm, keratinocytes carry IL-1, both $\alpha$ and $\beta$ forms (65). IL-1 is the key initiator of keratinocyte activation and is rapidly processed and released after injury (66). Keratinocytes express both types of IL-1 receptors and their antagonist making them highly responsive and sensitive to the effects of IL-1. IL-1 functions as an autocrine signal for keratinocytes to enhance the activation cycle (67) (Figure 4). IL-1 plays a crucial role for the paracrine signalling as it activates endothelial cells, fibroblasts and lymphocytes. IL-1 is a chemoattractant for lymphocytes and together with activation of endothelial cells and induction of selectin expression, IL-1 initiates lymphocyte extravasation (68). Cytokines and growth factors induced by IL-1 in keratinocytes include granulocyte-macrophage colony stimulating factor (GM-CSF) (69), tumour necrosis factor $\alpha$ (TNF- $\alpha$ ) and transforming growth factor $\alpha$ (TGF- $\alpha$ ), as well as IL-1. TNF- $\alpha$ has been shown to maintain the activation of keratinocytes (70) and elevated levels have been found in conditions like irritant contact dermatitis and infections (71). The maintained activation leads to production of several cytokines 
like IL-3, 6 and 8, which contribute to the paracrine signalling of keratinocytes in the wound healing environment $(5,72)$.

A.

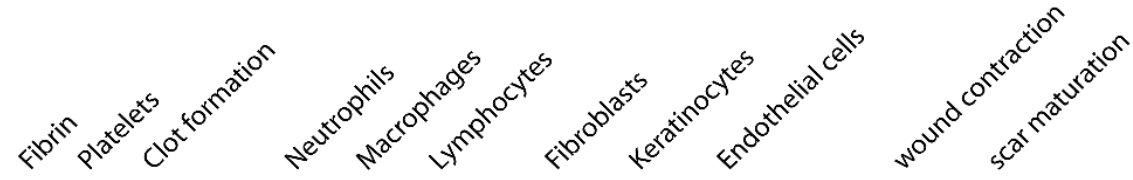

\begin{tabular}{lllcll} 
HAEMOSTASIS & INFLAMMATION & PROLIFERATION & \multicolumn{2}{c}{ REMODELLING } \\
\hline 1 hour & day 1 & day 3 & 1 week & 1 month & years
\end{tabular}

B. Day 3 Inflammation

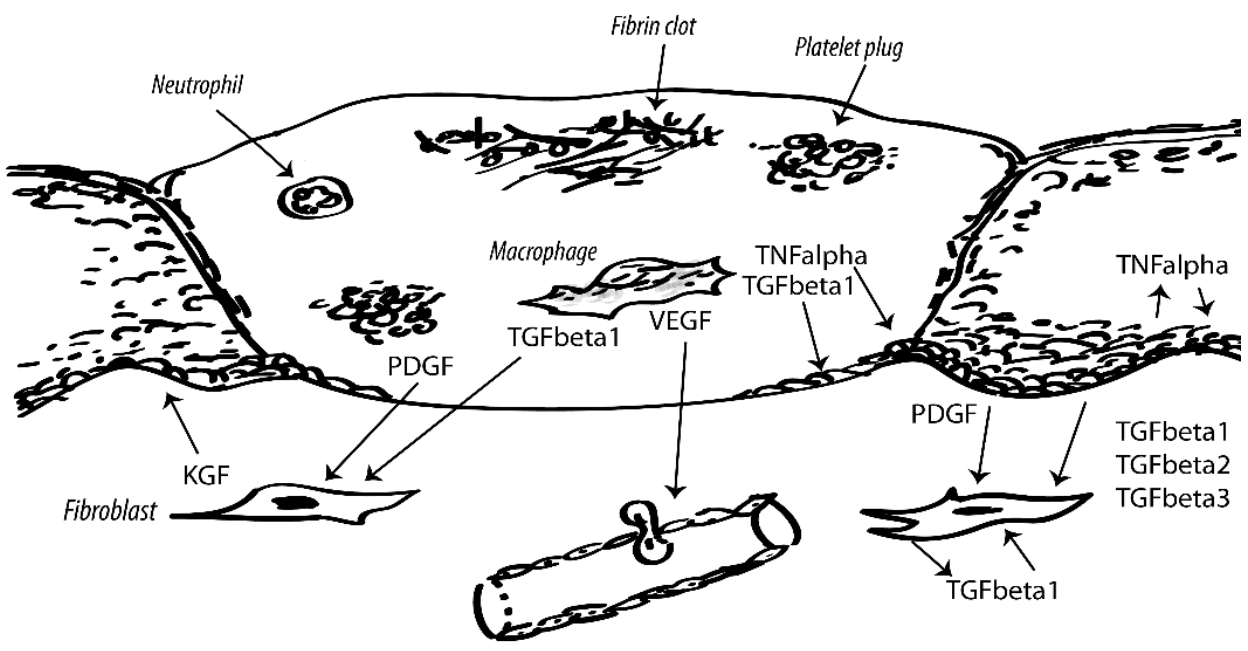

Figure 3. (A) The overlapping stages of the wound healing process at different times after wounding. (B) Schematic overview of the inflammatory phase of wound healing with involved cell types and soluble factors. KGF: keratinocyte growth factor, PDGF: platelet derived growth factor, TGF: transforming growth factor, TNF: tumour necrosis factor, VEGF: vascular endothelial growth factor. (A) adapted from Komosinska-Vassev et al. $2014^{122}$ (B) from Singer et al. $1999^{32}$ 
The signals form a positive feedback loop with increased production and upregulation of cell surface receptors and intercellular adhesion molecule 1 (ICAM-1) and integrins, essential for the migration of keratinocytes when the reepithelialisation of the wound starts (5). The integrins expressed on activated keratinocytes allow interaction with fibrinogen and collagen type I which is present in the wound edge and interwoven with the fibrin in the blood clot. As the keratinocytes migrate to cover the wound bed they are guided by the array of integrins they express (73). The migrating keratinocytes create an optimal environment for migration in additional ways: they contribute to the degradation of the ECM, which is necessary for migration to take place, by producing collagenase and matrix metalloproteinases (MMPs) $(74,75)$. The new stroma, referred to as granulation tissue, starts filling out the wound bed after day four in the wound healing process. Produced by fibroblasts, the new connective tissue is rich in capillaries $(58,76)$. Both angiogenesis and vasculogenesis, with recruitment of bone marrow-derived progenitor cells, contribute to the vascularisation of the granulation tissue in the proliferative phase of wound healing (77). The formation of a vascular network is pivotal for tissue repair in terms of oxygenation and nutrient supply (78). Fibroblasts and macrophages continue moving into the wound as the provisional matrix is formed. Macrophages sustain the growth factor production to induce proliferation of all surrounding cell types and fibroblasts produce and deposit ECM rich in fibrin, fibrinogen and hyaluronic acid $(51,79)$. The provisional wound healing matrix and granulation tissue that enables migration of keratinocytes and fibroblasts, and oxygenation, is gradually replaced by fibroblasts that start depositing a collagenous matrix (80).

A contained proliferative burst is required to sustain the re-epithelialisation process. The keratinocytes behind the actively migrating wound edge start proliferating one to two days after injury (51). The inducing factors have not been established. The free edge effect has been proposed as one of the mechanisms 
where the absence of neighbouring cell, in combination with growth factors, signals both migration and proliferation (58). As re-epithelialisation is completing, the basement membrane components collagen type IV and laminin reappear and fibronectin and fibrinogen are downregulated (57). At the late stage of reepithelialisation where contraction of the restored basal membrane is required the activated keratinocytes obtain a contractile phenotype that is characterised by expression of keratin $17(5,81)$. Keratin 17 is present in basal layers of pseudostratified epithelia and myoepithelial cells, which have in common that they contract or change shape. The expression of keratin 17 in epidermis is restricted to the activated contractile keratinocyte and directly induced by interferon y (IFN-y) $(38,82)$. IFN- $\gamma$ is an autocrine signal for lymphocytes and a paracrine signal for keratinocytes conveying the signal of the late inflammatory response (83). A deactivation signal in the form of TGF- $\beta$ is expressed at this time in the wound healing process by dermal fibroblasts. TGF- $\beta$ suppresses keratinocyte cell proliferation and directly induces basal-specific expression of keratin 5 and 14 (84). The effect of TGF- $\beta$ on keratinocyte activity has been shown to be reversible and does not lead to terminal

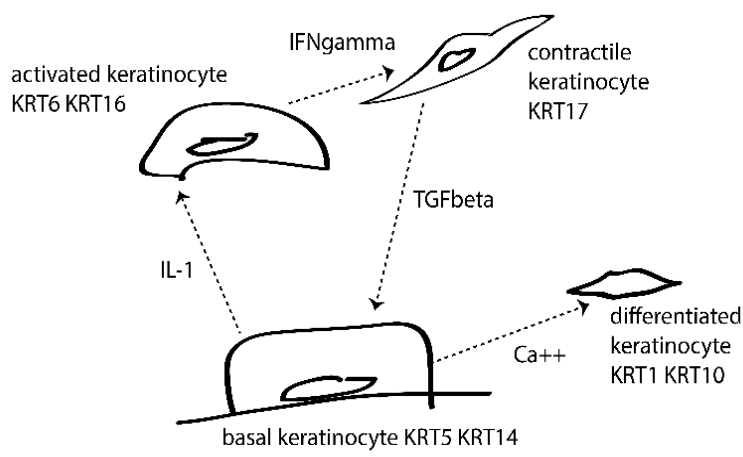
differentiation but reduces the growth rate back to a normal basal level $(85,86)$.

The remodelling phase of the wound healing process is the long process of ECM reorganisation at the site of injury that will eventually lead to the formation of a 
fibrous scar. The maturation of a scar can take years to complete. The initiation is characterised by the apoptosis of granulation tissue fibroblasts, a process for which no inducing signal is known $(87,88)$. With this, the formation of granulation tissue is stopped and the collagen type III that was deposited during the inflammatory phase is degraded. It is replaced by type I collagen oriented in small parallel bundles, different to the basket weave organisation of normal dermal collagen. This orientation of collagen I is responsible of the different texture and appearance of a cutaneous scar (89). During the remodelling phase, fibroblasts in the vicinity of the wounded area obtain a contractile phenotype referred to as myofibroblast (90). Myofibroblasts contribute to the closing of the wound by contracting the remodelling ECM and diminishing the wound area. Mature myofibroblasts express $\alpha$-smooth muscle actin ( $\alpha$-SMA) stress fibres. The most well accepted inducer of myofibroblast activation is TGF- $\beta 1(91,92)$. TGF- $\beta 1$ and 2 are key regulators of the inflammatory phase of wound healing, and play a role in promoting fibrous scar formation $(93,94)$. Excessive expression of TGF- $\beta 1$ and 2 has been shown to promote aberrant scarring, and dysregulation of the remodelling phase is manifested as hypertrophic or keloid scarring. In both cases the deposition of scar tissue is extensive, forming raised scars. Hypertrophic scars remain within the boundaries of the original injury whereas keloids grow beyond $(95,96)$. Myofibroblasts are also involved in the pathophysiology behind hypertrophic scars, especially following burn wounds, where myofibroblasts are numerous and heavily contract the scar. Scar contraction can be painful and disabling, and persists as a major complication following burns (91).

\section{Non-healing wounds}

Patients suffering from non-healing, or chronic, wounds are a large patient group in today's health care systems (97). The complications impose morbidity and mortality on mostly the elderly patient group and bring about suffering for long 
term patients with pain and substantial effects on quality of life (98). Treatment times are often prolonged and the risk of recurrence is high, and it is estimated that $2 \%$ of health care budgets in Scandinavia are consumed by costs associated with chronic wounds (99). A prevalence estimation of foot and leg ulcers on the Swedish general population is $0.12-0.2 \%(100,101)$.

The term chronic wound includes all wounds that fail to heal and include venous and arterial leg ulcers, diabetic foot ulcers and pressure ulcers (102-104). Cancer and radiotherapy can also lead to impaired healing (105), and all these preconditioning states are more prevalent in older adults. This patient group also undergoes surgery more often which increases the risk for chronic wound complications. Conditions that affect the vascular system affect the vasoregulation of the microcirculation of the skin which can lead to hypoperfusion (106). This reflects in changes in the inflammatory response in the skin during wound healing, low oxygen tension and poor nutrient delivery $(107,108)$. The resident cells in the chronic wound are also characterised by decreased proliferation rates and morphology resembling senescent cells. Fibroblasts isolated from venous leg ulcers have been shown to have a reduced response to PDGF and lower expression of TGF- $\beta$ receptors compared with normal dermal fibroblasts. These are similar responses seen in fibroblast exposed to hypoxia, indicating that chronic wounds are hypoxic $(107,109,110)$.

Chronic wounds are often characterised by being halted in the inflammatory phase of the wound healing process (111). An increase of cellular infiltrates that is persistent in a chronic wound leads to the prolonged presence of neutrophils and macrophages. This leads to the dysregulation of some of the key regulators of the inflammatory phase: IL- $1 \beta$ and TNF- $\alpha$ have been shown to prolong the inflammatory phase and delay wound healing $(112,113)$. Venous stasis ulcers are the most prevalent lower limb ulceration (114). Venous hypertension is caused by 
an obstruction or reflux, and the venous insufficiency resulting from it leads to dilation of capillaries and leakage of plasma proteins, fibrin deposition and a lower oxygen tension in the tissue. The effects are ischemia and hypoxia which leads to cell death and ulceration (115). The venous leg ulcers have many underlying pathogeneses but have in common the complications that are caused by prolonged inflammation times. This often leads to substantial microbial colonisation, a system that once established can sustain itself $(116,117)$. The chronic ulcers also have an aberrant expression of MMPs due to the elevated levels of IL- $\beta 1$ and TNF$\alpha$ (112) and their locally expressed inhibitors (118) and inflammatory cytokines which degrade the ECM and vascular walls in the healing wound environment. In the case of diabetic foot ulcers, oxidative stress has been identified as one of the key problems. The stagnation in the inflammatory phase leads to continuous infiltration of neutrophils that release free radicals and inflammatory mediators, which causes cytotoxic effects on the surrounding tissues and delays wound closure $(116,119)$.

\section{Wound treatment - dressings, skin substitutes and scaffolds}

There are several types of different wound dressings for the treatment of nonhealing wounds aimed to enhance wound healing. The foremost contribution of coverage of a wound with a dressing is the barrier effect it has and the maintenance of a moist wound healing environment (120). Providing a temporary barrier to reduce infection and minimise necrosis is the first line of action. Open wounds are frequently contaminated and chronic wounds are easily colonised with bacteria that can start spreading into the tissue, and infect the wound. The poor vascularisation and devitalised tissue that offers a favourable milieu for microorganisms contribute to the risk of infection. Debridement, cleansing and coverage are essential to minimise colonisation and prevent severe infection (121, 122). Moist or wet treatment of wounds has been shown to enhance the wound 
healing process seen by a promotion of re-epithelialisation and reduction of inflammation. Before the 1960s and the introduction of the idea of moist wound healing, wounds were often treated dry with the notion that infection would be easier to combat in a dry environment (123), until Winter et al. showed accelerated re-epithelialisation of wounds on pigs treated with occlusive dressings (124). In 1963 Hinman and Maibach showed occlusion of experimental wounds to be beneficial when treating human wounds (123). Since then, moist dressings are standard care for chronic ulcerations (125). There is a vast range of dressings with a multitude of mechanisms of actions including incorporated antibiotics and growth factors (126-134). Dressings and occlusion have also been utilised to modulate components of the local wound environment, like $\mathrm{pH}$ value. With limited clinical evidence of enhanced wound healing and difficult interpretation of clinical trials with few randomised controlled trials available, simple dressings can be considered as a protective barrier to provide a suitable wound healing environment (111). An optimal wound dressing should fulfil certain criteria: provide hydration but remove exudate and be impermeable to microbes, but allow gas diffusion. The dressing should not release unfavourable agents or fibres, and not harm the periwound area when removed. Finally, the product should be easy to use and cost effective. Few dressings meet all requirements (134).

Efforts to improve wound healing are of course not restricted to chronic wound problematics. Burn patients are a large patient group with acute need for barrier restoration. Immediate measures taken are removal of necrotic tissue and wound coverage and subsequent autologous split or full thickness skin grafting with the goals of minimising bacterial colonisation to avoid sepsis, and to preserve as much of the unharmed tissue as possible (135). The problem with large burns is the scarcity of healthy donor sites for a graft, and donor site morbidity due to the poor general status of the patients. Cultured epidermal autografts were introduced in the 1980s (136). Keratinocyte sheets can be expanded and stratified in culture before 
reintroducing them to the patient (137). A drawback is the long culture time required (135). To solve disadvantages of using epidermal autografts, autologous keratinocytes can be transplanted before reaching a confluent state as a single cell suspension, often with fibrin sealant $(138,139)$. The keratinocytes retain their proliferative state and contribute to re-epithelialisation (140). The greatest advantages are the shortening of culture times and the ease of handling. When transplanting subconfluent keratinocytes, the total cell viability is also higher compared with epidermal autografts (141). Autologous transplantation of keratinocytes, as epidermal autografts or in suspension, is a life saving measure that has improved burn wound care substantially, however the methodology does not support regeneration of the complete skin. The dermal component is still lacking, and transplantation sites are left with a thin, brittle skin that lacks thermoregulation, hair follicles and has sensory deficiencies (142).

\section{Skin substitutes and scaffolds}

There are several approaches to substituting the dermis, ranging from applying a scaffold for resident cells to populate as a way to induce guided tissue regeneration, to engineered constructs with living cell components (143-146). Initial tissue engineering efforts to replacing tissues utilised materials that were inert, with the notion that the material could not degrade and harm the host (147). Later development has led to the use of degradable scaffolds that aims to deliver cells, genes and/or proteins to the harmed tissue and gradually degrade, leaving space to

the regenerated tissue. The ultimate scaffold will support tissue regeneration by preserving the tissue volume, and guide ingrowth and regeneration of the native tissue (148). The degradation rate of the scaffold should match the rate by which the new tissue is regenerated at the site of implantation and the scaffold should provide structural integrity to the damaged tissue for a certain period of time before adapting to the environment. Tissue guidance is allowed by an open scaffold system, where eventually the complete scaffold will be degraded or completely 
integrated with the host (149). Scaffold design in terms of choice of material and porosity, besides the obvious biocompatibility, plays a large part in the suitability of the material for tissue engineering purposes. The target application dictates the requirements set on the material of choice, but in general terms the selection is based on the physical, mass transport and interaction properties (150). Moreover, mechanical strength of the material, gelation and diffusion properties need to be considered. Out of mass transport properties, diffusion is the most important one to provide oxygenation into the scaffold, and will depend on both size of the molecule and charge interactions with the scaffold material (151-153). The mechanical strength dictates the space filling properties of the material and the degradation rate that is crucial for optimal performance. The rigidity of the scaffold is also important in terms of mechanical input to the native cells (154-156). Porosity coheres with the gelation of a material and its subsequent topography and biological properties. As the scaffold is to be implanted, it should promote cellular function in order to work as a guiding scaffold. Adherence, proliferation and differentiation of cells should be supported (151).

Hydrogels have been extensively investigated in the field of tissue engineering of skin. The structure of gels with high wettability ( $\geq 30 \%$ water content by weight) $(151,157)$ is similar to macromolecular components of connective tissue and suitable for implantation due to the low strain on native tissue they exert. Both synthetic and biological degradable polymers are utilised for hydrogel production. The most applied synthetic polymers include polylactic acid (PLA), polyglycolic acid (PGA) and polycaprolactone (PCL) (149) . Synthetic polymer scaffolds with the aim to restore the epidermis have largely been unsuccessful, mainly due to the low cellular recognition and compatibility (158). Efforts are being made to combine the synthetic polymers with biopolymers to make use of preferable properties from both. Synthetic polymers have the advantage of fabrication where desirable physical features can be added (159) and the natural biopolymers carry a 
biocompatibility that allows adherence of cells carrying adhesion molecules for natural components (151). Degradable biopolymers used in scaffolds for regeneration of skin explored today are mostly based on agarose, alginate, chitosan, fibrin, hyaluronic acid, gelatin and collagen.

Acellular constructs are designed to mimic ECM components and to provide a dermal scaffold to support dermal regeneration (160). Early studies on materials for wound dressings and skin tissue engineering understandably focused on collagen, and being the main component of the ECM there are several collagen based dressings on the market today in the form of gels, sheets and sponges. For tissue guidance, acellular dermal allografts are available commercially today. One of the most established is AlloDerm (LifeCell, Branchburg, NJ) (159) derived from human cadaveric skin that is acellularised, lyophilised and glycerolised. It naturally resembles the native dermal tissue (161). Today, AlloDerm is primarily applied to partial and full thickness burns, but also used for soft tissue replacement and reconstruction of abdominal wall defects (162). Cellular dermal allografts are the next level of complexity of skin substitutes, where a bovine or porcine collagen matrix is seeded with neonatal fibroblasts that remain viable for a limited time, but exert positive effects for regeneration of the dermal tissue (163). These constructs are focused on the aiding in regeneration of a dermis, but efforts are being made to provide constructs with both dermal and epidermal components. Integra (Integra LifeSciences, Plainsboro, NJ) is a synthetic bilayer product. It is a composite of collagen and chondroitin-6-sulfate of bovine origin with a silicone cover sheet (164). The matrix is engineered to have pores in the range of $20-50 \mu \mathrm{m}$. Three to four weeks after implantation for tissue guidance for dermal cells, the silastic cover is removed and an epidermal graft can be placed on the treated area. Both AlloDerm and Integra have been largely successful in providing resident cells with a space filling guiding scaffold, and more importantly in preservation of tissue volume after large trauma or burns. Nonetheless, they are hampered by high costs 
and the need for several surgeries if an epidermal component is to be added. The prototypes for human allogenic skin substitutes including both dermal and epidermal components are Apligraf (Organogenesis, Canton, MA) (165) and OrCel (Ortec Intl.Inc., NY) (166). The dermal matrix is a bovine type I collagen gel with embedded neonatal fibroblasts. Neonatal keratinocytes are seeded on top of the constructs. These types of constructs are the most advanced products for treatment of wounds and present the closest resemblance to native tissue. The use of cellular allogenic composites is restricted due to high costs compared with conventional treatment strategies, a statement which in turn is debated when taking into account the quality of healing and loss of recurrence and later contacts with the health care system for the patients (162) .

\section{Gelatin microcarriers}

Bilayer constructs and dermal allografts represent scaffolding that are of a rigid nature and present a need for prefabrication. CultiSpher-S gelatin porous microcarriers (Percell Biolytica, Sweden) are degradable microcarriers ranging in size from $70-170 \mu \mathrm{m}$ in diameter (Figure 5). The carriers are used in suspension, enabling the use of the scaffold for any type or size of lesion. CultiSpher-S consist of porcine type A gelatin that is highly

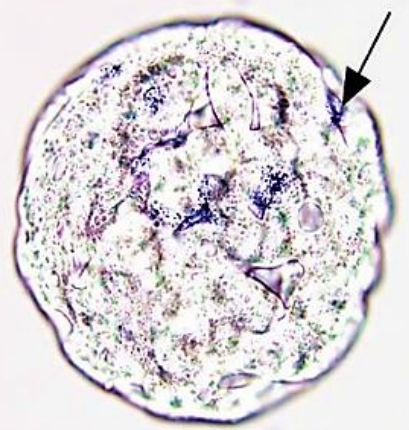

Figure 5. CultiSpher-S porous gelatin microcarrier. Size $=170 \mu \mathrm{m}$. Arrow indicates live keratinocyte. crosslinked. Gelatin is a derivative of collagen and therefore highly biocompatible and suitable as a biomaterial for guided regeneration of skin. The triple helix structure unique for collagen can be broken to obtain single chains, i.e. gelatin. Type A gelatin is obtained by acidic treatment of collagen (167). Gelatin has been widely investigated in different biomedical applications due to its natural origin, biocompatibility and degradability (168). 
The CultiSpher-S microcarriers have a porous structure which greatly enhances the surface area for cell adhesion with pores that range in size from 10-20 $\mu \mathrm{m}$. The adhesion properties of the microcarriers makes them suitable for cell expansion for transplantation purposes or large scale biomolecule production (169) and several cell types have been successfully cultured on CultiSpher-S (170). The porosity of the microcarriers also contributes to the mass transfer properties of the scaffold by creating an open scaffold where nutrients and oxygen can passage freely.

Previous work utilising the CultiSpher-S microcarriers reflect the versatility of possible applications for porous gelatin carriers. The work includes investigations of microcarrier culture of primary keratinocytes aimed for transplantation and the transplantation of keratinocytes to full thickness wounds in rats $(171,172)$, the microcarriers as soft tissue guiding scaffold in mice (173) and humans (174), and engineering of bone and cartilage-like tissues with the aid of gelatin microcarriers $(175,176)$. The suitability of gelatin microcarriers for keratinocyte expansion and as transplantation vehicle has been established, accordingly in paper I the aim was to investigate the gelatin microcarriers for their scaffolding properties for epidermal cells without added cells. The foremost questions were which cells in the wounds would populate the scaffold and what organisation the tissue would obtain. Additionally, the use of CultiSpher-S in suspension in in vitro wounds was tested. A suspended three dimensional matrix that is malleable extends potential to use in different types and forms of skin lesions where no pre-fabrication of a scaffold would be needed.

\section{Modelling skin and wound healing}

There is no fully functional in vitro modelling system to model the complexity of the wound healing process of human skin. Basic molecular understanding of wound healing has primarily been discovered by the use of animal models. This hampers the transition from pre-clinical studies to clinical studies (177). The few 
clinical studies in turn are difficult to implement due to the complex patient group and differences in underlying conditions that can affect the wound healing process. Animal models can never fully represent human wound healing and the use of animal models should always be restricted from an ethical point of view and (178). Modelling systems for investigating any physiological process or pathological responses are still of undisputed importance to identify biological targets and treatment strategies. For wound healing, numerous factors dictate the choice of model. General healing or only limited parts of the process can be of interest, or delayed or excessive healing, which all require different models to investigate (179).

The simplest of models to investigate wound healing responses is the use of single cell layers of keratinocytes in a scratch assay. This is merely a method to investigate keratinocyte proliferation and migration, and it has been used for investigating migration of keratinocytes in papers II and III. Using single cell layers and scratch assays limits the conclusions that can be drawn from the assay to concerning keratinocyte activation and migration only $(180,181)$. Studies on the contractile properties of fibroblasts or fibroblasts extracted at different stages of scar maturation are also performed with the aid of simpler in vitro models, often accompanied by contraction assays involving collagen gels (182). However, the complexity of wound healing with paracrine and autocrine interplay between the dermis and the epidermis cannot fully be reflected in cell assays. To add levels of complexity, skin substitutes have been developed and used for wound healing assays alongside wound treatment $(183,184)$. The organotypic models where individual components can be manipulated are an important tool for identifying specific factors or mechanisms of action, but remain incomplete in barrier function and ECM composition. 
The benefit of using a whole animal model is the inclusion of circulatory and systemic responses. Model animals frequently used in pre-clinical studies of wound healing are rats and mice. Transgenic mouse models have contributed to the field in terms of specific gene products and their contribution to the wound healing process $(185,186)$ and by providing disease models $(187,188)$. The translational problem that stems from using rodents is that the biology of the skin and subsequently the wound healing process in rodents is different from human. The skin of rats and mice has fur and contains a subcutaneous layer of striated muscle, the panniculus carnosus. The overlaying skin is loosely attached to the supporting structure (189) and a combination of loose skin and its contractile properties makes wound contraction the main mode of action of healing in rodents (190). Excisional wounds in rodents require splinting to allow investigations on re-epithelialisation and granulation tissue effectively, which introduces an external impact on the wound healing process (191).

In terms of structure and physiology of the skin the ideal animal model for studying wound healing is the porcine model $(192,193)$. The wound healing process is in general similar in human and pig, and pig skin has a similar vasculature and the same proportions of epidermis and dermis as human skin. The physical size of the animal enables multiple wounds to be placed on one animal (179). Despite the benefits of employing pigs as model animals their use is restricted due to high costs and need for specialised facilities (194).

Experimental treatment strategies for wound healing in human subjects are performed at opportune conditions in clinical settings on chronic wound patients and on split-thickness donor sites (195). The infliction of incisional wounds have long been implemented (196) though the use of human subjects is always ethically constrained due to the pain and discomfort that experiments may cause, and the possibility of obtaining persisting scars. The use of human wound tissue samples 
in combination with large animal models has been suggested (193). In a consensus statement, Baird et al. propose hypothesis construction to be based on human tissue samples and analysis by genomic and proteomic methods to identify targets and mechanisms that later would be investigated in animal models, and that tissue validation studies could contribute to more translationally relevant studies.

In research concerning the barrier function of the skin, human subjects have been exposed to known irritants by the means of occluded patch testing. The reaction in the skin has traditionally been evaluated on the basis of inflammatory symptoms (197). The use of human subjects is limited by the discomfort caused and subsequently that the exposure times have to be kept short. The clinical manifestations of irritants are difficult to determine visually, and one of the strongest arguments against patch testing has been the subjectivity of the analysis (198). The same concerns are raised in the use of the classic Draize test for toxicology and irritant testing. The Draize test is performed on small rodent eyes or skin and the adverse effects are recorded. Deemed cruel, the method has been challenged due to the inherent differences between humans and the model species (199). Alternative methods based on human reconstituted skin models are being developed, out of which few have reached the last validation steps according to the guidelines set by ECVAM, the European Centre for Validation of Alternative Methods. These lack the full barrier system of the skin which is of utmost importance for predictive results in irritant testing.

\section{Human full thickness skin in vitro}

The uniting factor in the four papers that constitute this thesis is the use of human full thickness skin in vitro. In papers I, II and III the human full thickness wound healing model has been used. In 1998, Kratz introduced a model based on tissue culture of viable human full thickness skin (200). Skin biopsies were cultured submerged in culture medium for up to four weeks, during which time cells 
remained viable in the tissue. Standardised full thickness wounds are created in the tissue with the aid of biopsy punches. The full thickness wounds are prepared with a punch that is three or four millimetre in diameter. A biopsy is taken with a larger, six or eight millimetre punch, creating single biopsies with circular wounds in the centre. Wound edge keratinocytes are activated and migration takes place as the keratinocytes re-epithelialise the three to four millimetre wounds in an average of seven days (Figure 6 A). This takes place when wounds are cultured in a maintenance medium consisting of Dulbecco's modified Eagle medium (DMEM) supplemented with $10 \%$ foetal calf serum (FCS). The cultivation of wounds in 2 $\%$ FCS results in a viable cell population but no re-epithelialisation. The $2 \%$ FCS culture condition could be considered as a non-healing environment with depletion of nutrients, and can be utilised to investigate treatment interventions for chronic wounds.

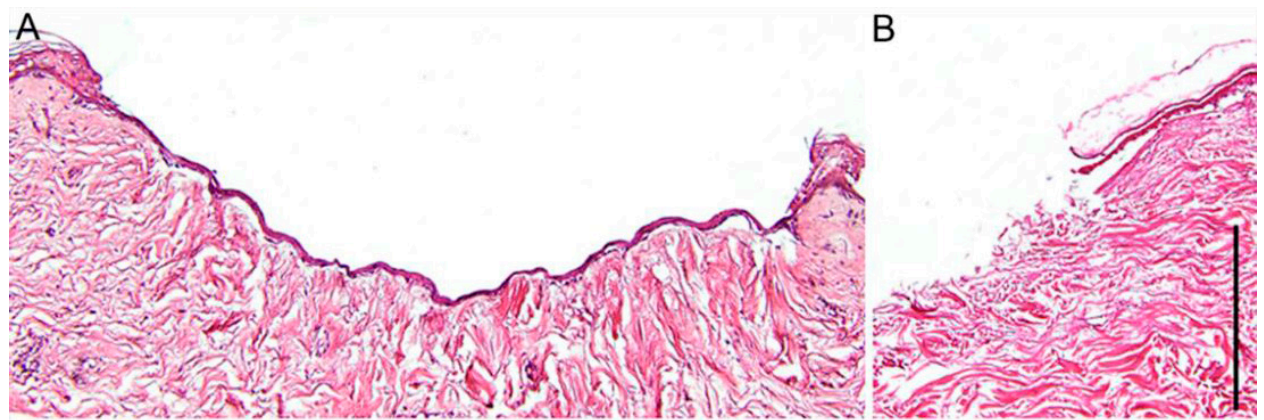

Figure 6. (A) Haematoxylin and eosin staining of a fully re-epithelialised in vitro wound after seven days of culture in Dulbecco's modified Eagle medium with 10 $\%$ foetal calf serum. (B) Representative image of wound edge of an in vitro wound presenting no re-epithelialisation. Scale bar $=500 \mu \mathrm{m}$.

The progress of re-epithelialisation is monitored by tissue preparation and paraffin sectioning, or cryosectioning, followed by routine haematoxylin and eosin (H\&E) staining (Figure 6). The re-epithelialisation can be measured or scored as complete or incomplete. In the occasion of a hair follicle present in the wound bed, the wound needs to be excluded from the analysis if only wound edge keratinocyte 
contribution is of interest. Since epidermal cells are present in the sheet of the hair follicle the origin of the cells in the neoepidermal tongue cannot be determined. The tissue sections can further be investigated with histological or immunohistochemical methodology.

In paper IV, human full thickness skin was used to evaluate its suitability to test cytotoxic effects of irritants. To test cytotoxicity the skin was left intact as this would be the case in a normal exposure of human skin to harmful compounds. The benefit of using full thickness human skin is the intact barrier system that the epidermis and the dermis forms. Problems arising from using reconstituted skin models or skin cell assays are the vulnerability of these systems and the overprediction this brings. The localisation on the body from which a sample for experiments is extracted plays an important role for irritant testing: thinner skin will be over-predictive for a reaction on a body localisation with thicker skin. This should be considered when planning for experiments. As selecting localisation of tissue sample is important for irritant testing, the same principles can be applied to inclusion in re-epithelialisation experiments. The foremost inclusion/exclusion criteria of interest would be any underlying condition that severely affects wound healing, like diabetes or other venous insufficiencies.

\section{Skin, wound healing and reciprocity}

Cutaneous wound healing is a dynamic process where the different phases overlap in time, and involve all constituents of the wound healing environment from resident cells to small fragments of the ECM. The reciprocity of the interactions between cells and the ECM has long been established and wounding is an example of the adaptability of the reciprocal interactions that take place when extensive disturbance to tissue homeostasis occurs. The term dynamic reciprocity was coined to describe how the interactions take place bi-directionally and change in response to cues from the microenvironment (201). The components of the ECM take part 
in all steps of the wound healing process and not only as a temporary matrix (202). The first response to wounding, the haemostatic response, is a demonstration of direct interaction between components of the ECM and the initiating factors in the wound healing process. As wounding occurs, cells and platelets in the vasculature are directly exposed to ECM components and haemostasis is initiated (203). Another example of direct contact is the extravasation of neutrophils and monocytes, where binding of cells to the affected endothelial cells and the exposed ECM is crucial for extravasation to occur. Once in the damaged tissue, monocytes bind to fibronectin in the wound environment which initiates phagocytic responses (204) and differentiation into macrophages (205).

The ECM provides not only the structural integrity of the tissue but also the cellular context for the cells present in the skin (206). Cells require to be supported and connected to neighbouring cells or an ECM in order to function. The ECM proteins support functions of cells by the multiple modes of interaction they present, and the cells respond to changes in the ECM (207). Integrins are the key players in conveying biochemical and structural changes from the ECM to cells, and integrins possess inside-out and outside-in signalling capacity. By binding the RGD motif, integrins are involved in the crosstalk between ECM proteins and the actin cytoskeletons (208), cell adhesion and migration (209), as well as growth factor responses (210). The ECM itself is a repository for growth factors that can be locally released to influence cells in the surrounding as a rapid response when wounding occurs (211). Several ECM proteins present affinity for both cell adhesion and growth factors which in turn-fine tunes the local availability of a growth factor to the vicinity of cell surface receptors (212). As important as a fast response to disturbed homeostasis is, is the modulation of the ECM when cellular functions need to be downregulated at the remodelling phase to avoid excessive scarring and damage to the tissue $(211,213)$. 
Fibroblasts are responsible for the deposition of granulation tissue and the ECM during wound healing. From being quiescent cells in the dermis, fibroblasts are activated to migratory cells with biosynthetic tasks (214). Mechanical stimulation through cues from the ECM (215) and activation by TGF- $\beta$ (216) signals resident fibroblasts to differentiate into contractile myofibroblasts. Keratinocyte-derived interactions have also been suggested, since fibroblast in co-culture with keratinocytes acquire contractile phenotypes after a short period of time (217). The interplay between keratinocytes and fibroblasts are prominent in the late inflammatory and the proliferative stages of the wound healing process (218). The importance of ECM and fibroblast support for keratinocyte proliferation are known and primary keratinocytes have long been cultured on feeder layers of irradiated fibroblasts. Demonstrated in the 1970s (219) the effects have been shown to be reciprocal: the keratinocytes influence the fibroblasts to express keratinocyte growth factor (KGF), IL-6 and GM-CSF to sustain a proliferative environment $(220,221)$. KGF expression in fibroblasts can also be induced in vitro by IL-1, TNF- $\alpha$, PDGF and serum (222), factors that all are initiating factors in the cutaneous wound healing response. Recent work by Larjava et al. (223) showed keratinocytes to directly affect fibroblast function via secreted vesicles. Keratinocytes contain microvesicles that can be shed, and when stimulating fibroblasts with microvesicles, pro-granulation tissue genes were upregulated in the fibroblasts in a dose-dependent manner. A third of the regulated genes were involved in TGF- $\beta$ signalling. Furthermore, microvesicles were shown to regulate release of MMPs, IL- 6 and IL-8. The role of microvesicles in the wound healing context is still to be elucidated, but it is one example of the various ways of interplay between the two main compartments of the skin and the cells that reside therein.

The complex nature of the wound healing process and its dynamic reciprocity speaks for modelling systems that take into account the contextual aspect of 
individual steps in the process. The use of human full thickness skin is a means of investigating the wound healing process in vitro without use of whole animals, yet still taking into account the epidermal and dermal contributions to reepithelialisation. The dermis and its ECM supports the function of epidermal keratinocytes both under normal and wound healing conditions. By utilising human full thickness skin in vitro with all its structural components, a comprehensive look on re-epithelialisation and barrier function of the skin can be achieved. 


\section{AIMS OF THESIS}

The overall aim of the work presented in this thesis was to investigate viable human full thickness skin in vitro to enable investigations on wound reepithelialisation and irritant responses.

The specific aims of the included papers:

I. To investigate the effect of providing resident cells in in vitro wounds with a porous gelatin microcarrier scaffold in suspension.

II. To develop a method to investigate the fate of keratinocytes and melanocytes in the re-epithelialisation process when transplanted to human in vitro wounds in suspension or on gelatin microcarriers.

III. To investigate the effects of acidic $\mathrm{pH}$ on re-epithelialisation of human in vitro wounds and keratinocyte function to evaluate the efficiency of lowering $\mathrm{pH}$ of the wound environment as adjuvant therapy for wound healing.

IV. To investigate human full thickness skin in vitro as a modelling system for cytotoxic effects of irritant compounds topically applied to human skin. 


\section{MATERIAL AND METHODS}

\section{Primary cell culture and media}

Keratinocytes and melanocytes were cultured in their respective maintenance medium (Table I) with medium changes three times per week. Fibroblast medium (FM) consisting of Dulbecco's Eagles modified medium (DMEM) supplemented with $10 \%$ foetal calf serum (FCS) was used for washing tissue and cells during cell preparation, and for centrifuging cells after passaging with trypsin. Primary keratinocytes and melanocytes (Figure 7) were prepared from full thickness skin biopsies under sterile conditions. Subcutaneous fat was removed by sharp dissection and the skin was washed in sterile phosphate buffered saline (PBS). For keratinocyte preparation, skin was cut into strips measuring one centimetre wide and three centimetres long and submerged in a DMEM solution containing 25 $\mathrm{U} / \mathrm{mL}$ dispase at $4{ }^{\circ} \mathrm{C}$ overnight. The epidermis was lifted off with forceps, minced with scissors, and placed in trypsin and ethylenediamine tetra acetic acid (EDTA) ( $0.25 \%$ and $0.02 \%$, Gibco, Thermo Fisher Scientific, Waltham, MA) solution for 15 minutes at $37{ }^{\circ} \mathrm{C}$. The solution was agitated every second minute by vortexing. The trypsin was inactivated with centrifugation at $300 \mathrm{G}$ in FM. The resuspended epidermis-cell suspension was cultured in keratinocyte serum free medium (KSFM), and non-adherent cells and debris was removed by rinsing with KSFM two days after seeding. Melanocyte preparation required removal of subcutaneous fat. The remaining epidermal and dermal tissue was minced with scissors, and placed in trypsin-EDTA solution and agitated with a magnetic stirrer continuously for 40 minutes at $37{ }^{\circ} \mathrm{C}$. After agitation, the tissue was left to sediment and the supernatant was collected, centrifuged in FM and resuspended in melanocyte growth medium (MGM). The procedure was repeated three to four times, and the supernatants were collected for seeding in appropriate culture vessels, depending 
on the amount of starting material. Culture medium change took place the day after seeding.

Table I. Composition of cell culture medium

\begin{tabular}{|c|c|c|c|c|}
\hline Medium & Abbreviation & $\begin{array}{l}\text { Basal } \\
\text { medium }\end{array}$ & Supplements & Manufacturer \\
\hline $\begin{array}{l}\text { Keratinocyte } \\
\text { serum free } \\
\text { medium }\end{array}$ & KSFM & $\begin{array}{l}\text { KSFM with } \\
\text { L-glutamine }\end{array}$ & $\begin{array}{l}25 \mu \mathrm{g} / \mathrm{mL} \text { bovine } \\
\text { pituitary extract (BPE) } \\
1 \mathrm{ng} / \mathrm{mL} \text { epidermal } \\
\text { growth factor (EGF) } \\
50 \mathrm{U} / \mathrm{mL} \text { penicillin } \\
50 \mu \mathrm{g} / \mathrm{mL} \text { streptomycin }\end{array}$ & $\begin{array}{l}\text { Gibco, Thermo } \\
\text { Fisher } \\
\text { Scientific }\end{array}$ \\
\hline $\begin{array}{l}\text { Melanocyte } \\
\text { growth } \\
\text { medium }\end{array}$ & MGM & $\begin{array}{l}\text { PC-1 base } \\
\text { medium }\end{array}$ & $\begin{array}{l}2 \% \text { PC-1 supplement } \\
1 \% \text { L-glutamine } \\
5 \mathrm{ng} / \mathrm{mL} \text { basic } \\
\text { fibroblast growth factor } \\
\text { (bFGF) } \\
24.6 \mathrm{~g} / \mathrm{mL} \mathrm{N}^{6}, 2^{\prime}-\mathrm{O}- \\
\text { Dibutyryladenosine } \\
3 \text { ',5'-cyclic } \\
\text { monophosphate } \\
\text { (dbcAMP) } \\
50 \mathrm{U} / \mathrm{mL} \text { penicillin } \\
50 \mu \mathrm{g} / \mathrm{mL} \text { streptomycin }\end{array}$ & $\begin{array}{l}\text { Base: Lonza } \\
\text { Supplements: } \\
\text { Sigma-Aldrich }\end{array}$ \\
\hline $\begin{array}{l}\text { Fibroblast } \\
\text { medium }\end{array}$ & FM & $\begin{array}{l}\text { Dulbecco's } \\
\text { Modified } \\
\text { Eagle } \\
\text { Medium }\end{array}$ & $\begin{array}{l}10 \% \text { foetal calf serum } \\
50 \mathrm{U} / \mathrm{mL} \text { penicillin } \\
50 \mu \mathrm{g} / \mathrm{mL} \text { streptomycin }\end{array}$ & $\begin{array}{l}\text { Gibco, Thermo } \\
\text { Fisher } \\
\text { Scientific }\end{array}$ \\
\hline
\end{tabular}
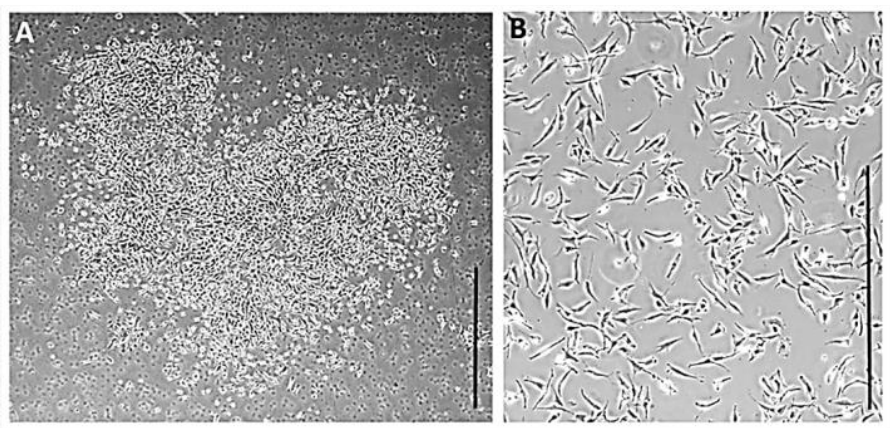

Figure 7. (A) Colony of primary human keratinocytes. (B) Primary human melanocytes. Scale bars $=1000 \mu \mathrm{m}$. 


\section{Microcarriers and spinner flask culture}

Porous gelatin microcarriers from PerCell Biolytica (Åstorp, Sweden) were applied to in vitro wounds in papers I and II. The aim of paper I was to investigate the scaffolding effects of the microcarriers. The CultiSpher-S microcarriers are based on highly crosslinked porcine gelatin type A and fully biodegradable (Figure 5). Cell culture on microcarriers requires agitation of the microcarriers suspended in culture medium which is done by using spinner flasks for culture (Figure 8) (Techne, Staffordshire, UK). The spinner flask is a basic bioreactor and one of the most commonly used in cell culture applications (224). Bioreactor design spans from microscale perfusion chambers to industrial size rotating wall vessels (225). The culture of cells on microcarriers in spinner flasks can be performed when the goal is to upscale the culture of adherent cells (226), since the use of spinner flasks reduces medium consumption

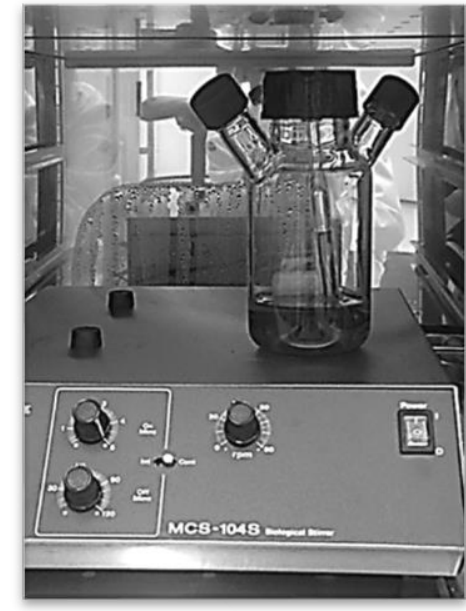

Figure 8. Spinner flask culture set-up with spinner flask and stirrer placed in incubator.

and hence the costs. The spinner culture also improves oxygenation and the distribution of nutrients for the cultured cells (224). For maximal cell proliferation to be achieved, mass transfer needs to be reached without the negative effects of the hydrodynamic forces present in the spinner culture (226). The cell damage in spinner flasks mainly rise from collisions between the microcarriers or with the agitator, or with interactions with liquid eddies when the cell-microcarrier suspension is agitated (227). An agitation rate enough to suspend the microcarriers can be sufficient for adequate oxygenation. However, if the spinning is the only mode of aeration of the culture the agitation speed might have to be increased. A 
liquid area can absorb only a limited amount of oxygen and this has to be considered when the culture volume of the spinner culture is decided: a larger volume of liquid will decrease the liquid surface/volume ratio and result in decreased oxygenation and lower cell yield (226). Other considerations than agitation speed and culture volume that need to be addressed are the carrier and cell type to make sure the adhesion of the cells is adequate. The possible reactions of the cells to the forces in culture should also be considered and the integrity of the microcarriers themselves exposed to the planned agitation speeds and culture times should be monitored (224).

The property of the microcarriers as tools for cell transplantation was utilised in paper II where cells were expanded on microcarriers before transferred to in vitro wounds. Keratinocytes and melanocytes were mixed with microcarriers at a concentration of 50000 cells $/ \mathrm{mg}$ microcarriers. The suspension was added to spinner flasks and agitated at 35 RPM for five minutes every hour for the first 24 hours of culture to allow cell attachment. After the initial phase, the culture was agitated continuously and half of the culture medium volume was changed three times per week. When microcarriers were transplanted to in vitro wounds, the spinner flask was manually agitated to obtain a uniform solution to remove the microcarrier samples from.

\section{Viability assay}

The 3-(4,5-dimethylthiazol-2-yl)-2,5-diphenyltetrazolium bromide (MTT) assay is a colourimetric assay for assessing metabolic activity of cells. The assay is based on the activity of mitochondrial reductases, which can reflect the number of viable cells in a sample. The enzymes reduce the yellow MTT salt to purple insoluble formazan. Once dissolved in dimethyl sulfoxide (DMSO) or isopropanol, the produced formazan is measured 
spectrophotometrically at $570 \mathrm{~nm}$ to quantify the absorbance (228). In paper II, MTT assays were performed on keratinocytes and melanocytes in adherent culture, and on both cell types cultured on microcarriers in spinner flask culture. In paper III, keratinocyte viability was investigated after exposure to acidic $\mathrm{pH}$. Cultures were incubated in MTT (Sigma-Aldrich, St. Louis, MO) dissolved in DMEM $0.3 \mathrm{mg} / \mathrm{mL}$ for four hours in the dark, after which incubation with DMSO took place for 10 minutes. In paper IV, the MTT assay was employed to investigate the cytotoxic effect of irritant compounds applied to human full thickness skin. Skin biopsies were submerged in MTT solution for four hours and the formed formazan was dissolved in isopropanol overnight at room temperature.

\section{Migration assay}

Migration of carboxyfluorescein hydroxysuccinimidyl ester (CFSE) stained keratinocytes and melanocytes (paper II) and keratinocytes exposed to acidic $\mathrm{pH}$ (paper III) was investigated by performing a scratch assay (180). Cells were seeded and cultured overnight to a confluent layer. Prior to the migration assay, the cultures were incubated with mitomycin C (Roche Diagnostics, Basel, Switzerland) for two hours at $37^{\circ} \mathrm{C}$. Mitomycin is a DNA cross linker that will inhibit proliferation in the culture and therefore excludes the contribution of proliferation to re-population of the scratch (229). The cell layer was then scratched with a p200 pipet tip to obtain a cell free area, which was monitored over a series of hours to investigate the migration of the cells into the cell free area (Figure 9). Analysis of the migration assay includes tracing the remaining areas that are not re-colonised by cells in the image processing analysis software FIJI (230) and compare the results with time point zero hours. Reults are presented as coverage of the initial cell free area in percent. 


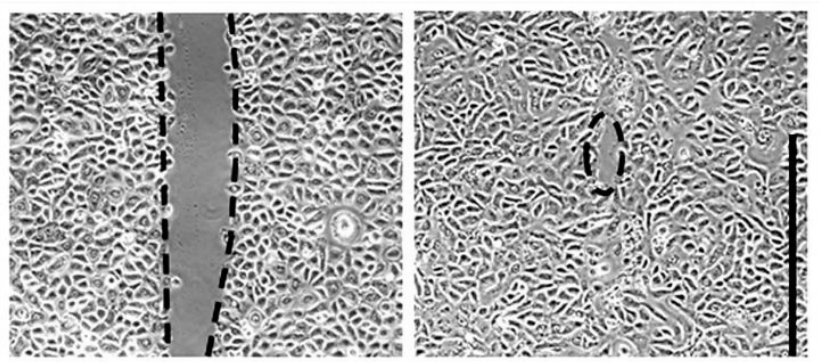

Figure 9. Scratch assay and progression of migration. Time point zero hours (left) with a distinct scratch in the confluent keratinocyte layer compared with time point 24 hours (right) of the same well where keratinocytes have re-populated the scratched area. Scale bar $=500 \mu \mathrm{m}$.

\section{Quantitative real-time polymerase chain reaction}

In paper III, the relative mRNA expression of certain genes of interest was investigated in keratinocytes exposed to $\mathrm{pH} 5.0$ and $\mathrm{pH} 6.0$ compared with untreated controls with the aid of quantitative real-time polymerase chain reaction (qRT-PCR) (231). Gene expression assays and reagents were purchased from Applied Biosystems (Foster City, CA). Total RNA was isolated from cells with High Pure Isolation Kit (Roche Diagnostics) and quantity and quality was measured with a NanoDrop 2000 (Thermo Fisher Scientific). RNA was transcribed to cDNA with High Capacity cDNA Reverse Transcription Kit (Applied Biosystems) and PCR was run using TaqMan Fast 96-well plates in a HT7900 thermocycler (Applied Biosystems).

The use of Taq polymerase for DNA replication applications was a break through when introduced. Previously polymerase activity was restricted by the high temperatures required to denature the newly formed DNA strands to enable the single strands to act as templates for the next round of amplification. The Taq polymerase was discovered in the bacterium Thermus aquaticus and isolated by Chien et al. in 1976 (232). Thermus aquaticus is resident in hot springs so the polymerase could now withstand the temperatures up to $95^{\circ} \mathrm{C}$ that are required for 
a PCR, and enabled reaction in a single tube and no addition of polymerase in the middle of running the PCR (233). The primer assays used in paper III were TaqMan probe based gene expression assays. TaqMan probes are primer probes that were developed by Roche Molecular Diagnostics and Applied Biosystems enabling real time monitoring of the accumulation of PCR product during the reaction. The probes are designed with a fluorophore at the 5' end and a quencher at the 3 ' end which quenches the fluorescent signal when in close proximity of the reporter fluorochrome, i.e. when the probe is intact. As the polymerisation proceeds, the exonuclease activity of the Taq polymerase cleaves the probe on the target sequence and allows a fluorescence signal to be detected. This enables continuous monitoring of the amplification of target sequences during the exponential cycles of the PCR and the relative quantification of the expression of genes of interest.

To analyse the data from gene expression experiments in paper III, a method to establish relative expression termed the $2^{-\Delta \Delta C t}$ method was used (234). The Ct value (cycle threshold value) of the gene of interest is the number of amplification cycles required to reach a threshold of fluorescence signal above the background and baseline signals. The basic assumption made is that one cycle difference in reaching the threshold represents a doubling of starting template in the PCR. The difference in $\mathrm{Ct}$ value, and thus the fold change, is obtained by relating the $\mathrm{Ct}$ value of the target gene to an endogenous control (hydroxymethylbilane synthase (HMBS) in paper III) and to an internal calibrator, in our case the untreated control cells. The application of endogenous controls normalises the expression and controls for variations in assays and experiments, as well as cDNA yield.

\section{Human in vitro wound healing model}

The in vitro wound healing model utilised in papers I, II and III is based on the culture of viable human full thickness skin. Preparation of in vitro wounds requires 
full thickness skin, cleared from subcutaneous fat. Skin samples were washed and kept moist in PBS. The adipose tissue was removed with scissors. Full thickness wounds were prepared by using standard $3 \mathrm{~mm}$ biopsy punches (Figure $10 \mathrm{~A}$ and B) to create circular wounds. This resulted in standardised full thickness wounds spanning over the dermo-epidermal junction into the dermis. The wounds were separated from the larger skin specimen with a $6 \mathrm{~mm}$ biopsy punch, to create $6 \mathrm{~mm}$ biopsies with a central $3 \mathrm{~mm}$ wound (Figure $10 \mathrm{C}$ ). The wounds were cultured in individual wells in 24-well plates in FM with medium changes three times per week in all three projects (Figure 10 D). In paper I, wounds were incubated in cell culture inserts (Figure $10 \mathrm{E}$ ). The placement of the wound in the air-liquid interface induces stratification of the epidermis, with cornified keratinocytes in the superficial layers of the newly formed epidermis of a re-epithelialised wound. Wounds with hair follicles present were excluded from analysis.

\section{Non-occlusive topical exposure}

In paper IV, full thickness skin in vitro was used to model reactions in the skin after exposure to irritant compounds. Cut-off strip tubes in pairs or in sets of three were used to create confined areas of exposure on the skin (Figure 11). The rings were pressed into skin that was cleared from adipose tissue to create chambers with exposure areas of $0.80 \mathrm{~cm}^{2}$. Sodium dodecyl sulphate (SDS) and other test substances, as well as PBS as DMEM controls were applied to the formed chambers and the samples were placed in an incubator. After pre-defined exposure times the centres of the exposed areas were extracted with a $3 \mathrm{~mm}$ biopsy punch. Biopsies were washed in PBS and submerged in $0.3 \mathrm{mg} / \mathrm{mL}$ MTT-solution (in DMEM) for four hours at $37{ }^{\circ} \mathrm{C}$. As described earlier, the formed formazan was precipitated using isopropanol at room temperature overnight. The optical density was measured using a plate reader (Versamax, Molecular Devices). Results were presented as relative to control substance values and expressed in percent. 


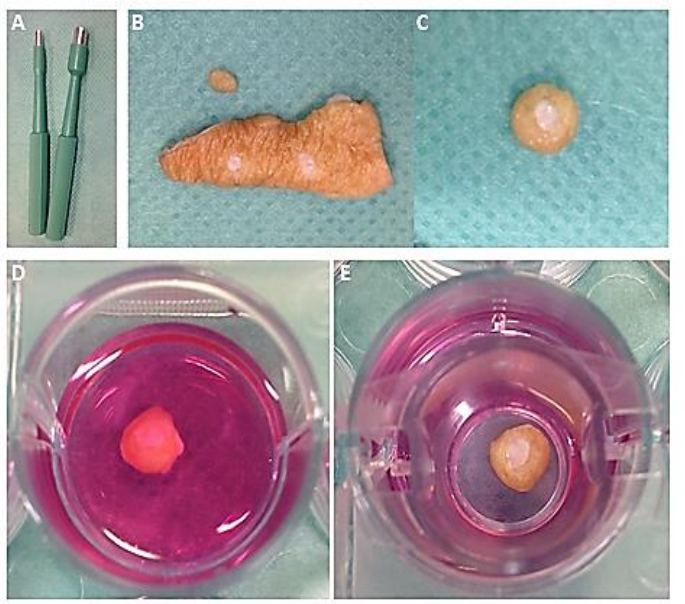

Figure 10. (A) Standard three and six millimetre biopsy punches for creation of in vitro wounds. (B) Full thickness skin sample with two in vitro wounds created with a three millimetre biopsy punch. (C) Single in vitro wound extracted from the whole skin sample with a six millimetre biopsy punch. (D) Submerged in vitro wound. (E) In vitro wound cultured in cell culture insert.

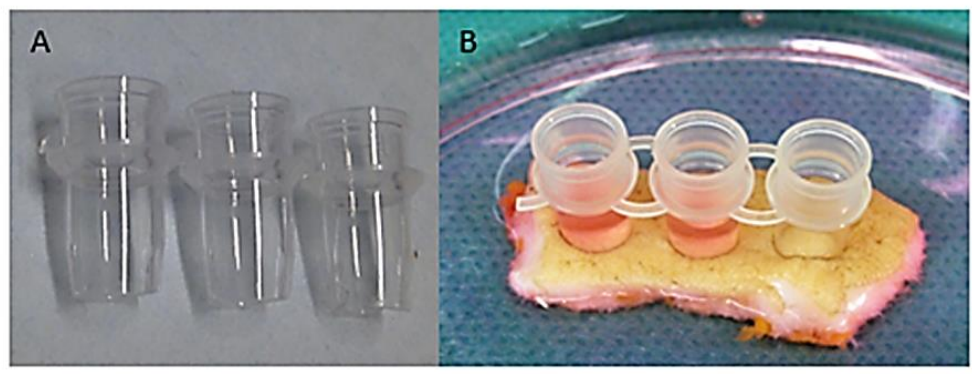

Figure 11. (A) Cut-off strip tubes in sets of three for creating restricted exposure areas on human skin for cytotoxicity testing. (B) Tubes pressed onto viable full thickness skin for non-occluded exposure to irritant.

\section{Paraffin embedding and sectioning}

Paraffin embedding of tissue samples and sectioning was performed in paper III. Paraffin embedding is routine methodology to obtain tissue samples of high morphological standard that can be stored for long periods of time. To begin the embedding process the in vitro wounds were fixated with $4 \%$ formaldehyde (PFA) (HistoLab, Gothenburg, Sweden) for four hours. The fixation substance and length of fixation depends on the tissue sample and downstream application. Formaldehyde in aqueous solution forms methylene glycol which reacts with several side chains of proteins. The formed reactive side groups react with each 
other or combine with hydrogen groups, thereby causing fixation of the proteins (235). After washing in PBS, tissue was dehydrated in ethanol. Lastly, the samples were submerged in Tissue clear, which is miscible with melted paraffin. After soaking in paraffin overnight, the samples were embedded in paraffin and left to cool to obtain hard tissue samples that can be sectioned, and stored at room temperature. Tissue was sectioned using a Leica RM2255 microtome (Leica, Wetzlar, Germany) in $10 \mu \mathrm{m}$ thick sections and baked on glass slides at $56{ }^{\circ} \mathrm{C}$ overnight.

\section{Cryosectioning}

Cryosectioning of tissue biopsies in the size range of the in vitro wounds is a faster method to obtain tissue sections compared to paraffin embedding and sectioning. However, the process of cryosectioning may lead to loss of structural morphology compared with fixated paraffin samples. Cryosectioning was preferred in papers I and II due to the presence of microcarriers in the wounds: early experiments revealed loss of microcarriers in the dehydration process and cryosectioning, which requires less preparation and change of solutes, was chosen as sectioning method. Samples were attached to sample holders with optimal cutting temperature compound (OCT) (HistoLab) and snap frozen by submerging in liquid nitrogen. Sectioning was performed with a Leica CM3050 cryostat at $-28{ }^{\circ} \mathrm{C}$ and tissue sections were placed on Superfrost plus glass slides (Thermo Fisher Scientific). The thickness of prepared sections was $10 \mu \mathrm{m}$ for routine staining described below and $50 \mu \mathrm{m}$ for confocal imaging in paper I.

\section{Haematoxylin and eosin staining}

Tissue staining with haematoxylin and eosin (H\&E) was used in papers I, II and III to observe morphology and to investigate the degree of re-epithelialisation of the wounds. H\&E is the most widely used staining method for tissue morphology investigations and histopathological assessments. Paraffin embedded sections in 
paper III were deparaffinised in tissue clear, rehydrated in ethanol, and subsequently washed in de-ionised water prior to staining. Frozen sections in papers I and II were air dried and washed in PBS to remove the OCT. Sections were stained with haematoxylin, washed under running tap water and stained with eosin. After staining, sections were dehydrated in ethanol and mounted with mounting medium (Mountex, HistoLab) and a cover slip. The times for staining in haematoxylin and eosin solutions varied depending on what type of fixation and preservation was used, with generally shorter staining times for frozen sections.

Eosins are routinely used as counterstains to haematoxylin nuclear staining. They are acidic and stain basic positively charged structures, and by staining with eosin one can distinguish cytoplasms of different cell types and different types of connective tissue in varying shades of red and pink. The intense staining of red blood cells can also facilitate the localisation of small vessels in the dermis of the skin. The differentiation of the stain takes place when the slides are dehydrated in alcohol after staining and is essential to obtain information and comprehensive images of the tissue slide. The haematoxylin stains are extracted from the logwood and are not stains in themselves: haematein naturally formed by oxidation carries the colour properties. Additionally, a mordant is required to increase the affinity of haematein to tissue. Mayer's haematoxylin used in papers I, II and III is an alum haematoxylin where the added mordant is aluminium salt. The metal cation gives a net positive charge to the complex of dye and mordant, and binding of anionic structures such as nuclear chromatin is made possible. Haematoxylin stains nuclei in a red stain that is blued by washing in a slightly alkaline solution, most often tap water. This results in the dark blue colour that characterises the haematoxylin stain (235). All sections were visualised using an Olympus BX41 light/fluorescence microscope (Olympus, Solna, Sweden) 


\section{Immunohistochemistry}

Immunohistochemical staining was utilised in papers I-III to visualise, localise and identify different proteins. The basic principle of immunohistochemistry is the use of targeted antibodies for a specific antigen of interest. The primary antibodies are targeted with secondary antibodies conjugated with a fluorochrome or substrate for enzymatic detection of the primary antibody. Fluorescent secondary antibodies were used in all three projects (Alexa Fluor 488 and 546, Molecular Probes, Thermo Fisher Scientific). In papers I and II, keratinocytes were targeted by staining with antibodies against both acidic and basic cytokeratins. In paper I, this was performed to visualise the neoepidermis of the wounds and to quantify the thickness, and in paper II for distinguishing resident keratinocytes from the CFSEstained, transplanted keratinocytes. In paper I the markers of a mature epidermis were targeted to investigate the maturation of the thick neoepidermis seen in the wounds with administered microcarriers (Table II).

Cryosectioned tissue samples (paper I and II) were left to air dry for 30 minutes prior to immunohistochemical staining. Paraffin embedded slides were treated with Tissue clear and washed in $99.5 \%$ ethanol and $95 \%$ ethanol prior to staining. All sections were fixated with $4 \%$ PFA except sections intended for staining with antibody against laminin 5 . These were fixated with cold acetone as suggested by manufacturer of the antibodies. After washing in PBS, unspecific binding sites for primary antibodies were blocked with $2.5 \%$ bovine serum albumin (BSA). Primary antibodies were applied in a humidified chamber for 60 minutes for 10 $\mu \mathrm{m}$ sections, and at $4{ }^{\circ} \mathrm{C}$ overnight for $50 \mu \mathrm{m}$ sections. Secondary Alexaconjugated antibodies were applied in a humidified chamber in the dark for 60 minutes. Slides were mounted with mounting medium Prolong Gold (Thermo Fisher Scientific) containing 4', 6-diamino-2-phenylindole (DAPI) for nuclear staining. Control samples with omitted primary antibodies were employed to ensure specificity of the secondary antibodies. The primary and secondary antisera 
used in the studies have been used in previous studies and tested for specificity and cross-reactivity (236-239).

Table II. Antigens targeted with immunohistochemical staining in paper I

\begin{tabular}{|l|l|c|}
\hline Antigen & $\begin{array}{l}\text { Keratin expressed by keratinocytes in the basal layer } \\
\text { of epidermis, expressed concurrently with keratin 14 }\end{array}$ & Reference \\
\hline Keratin 5 & $\begin{array}{l}\text { Keratin expressed by keratinocytes in the superficial } \\
\text { layers of epidermis, expressed concurrently with } \\
\text { keratins 1 and 2 }\end{array}$ & $(241,242)$ \\
\hline $\begin{array}{l}\text { Laminin, alpha } \\
5\end{array}$ & $\begin{array}{l}\text { Extracellular anchoring filament and major } \\
\text { component of hemidesmosomes in basal membranes }\end{array}$ & $(46)$ \\
\hline Ki-67 & Nuclear antigen present only in proliferative cells & (243) \\
\hline
\end{tabular}

\section{Carboxyfluorescein hydroxysuccinimidyl ester (CFSE) staining}

Cell staining with 5(6) carboxyfluorescein N-hydroxysuccinimidyl ester (CFSE) is conventionally used for proliferation measurements of lymphocytes. The nonfluorescent pro-dye passively moves over the cell membrane due to the presence of two acetate groups (244). Once inside the cell, intracellular esterases remove the acetate groups and a green fluorescence is yielded (Figure 12). The membrane permeability of the molecule is reduced and the succimidyl groups present form covalent bonds with amino groups, mainly lysine residues. The now covalently linked conjugates of the stain can persist in lymphocytes over months and results in a fluorescent staining that is sequentially halved at every cell division.

In paper II we have employed CFSE-staining for passive staining of primary keratinocytes and melanocytes for tracing transplanted cells in tissue sections of in vitro wounds. Keratinocytes and melanocytes were stained adherently according to same protocol with caution to expose the stain solution or the stained cells to bright light. CFSE (Molecular Probes, Thermo Fisher Scientific) was diluted in DMSO to $5 \mathrm{mM}$, and diluted to working concentrations in pre-warmed $\left(37{ }^{\circ} \mathrm{C}\right)$ PBS. Three millilitres of CFSE solution was added to adherent cells in a $75 \mathrm{~cm}^{2}$ 
flask and the flask was agitated for two minutes. Cells were incubated at $37{ }^{\circ} \mathrm{C}$ for 15 minutes and medium was changed to pre-warmed cell culture medium. After 30 minutes in the fresh medium cells can be harvested or left for expansion. Keratinocytes and melanocytes cultured on microcarriers in paper II were stained as described prior to attachment to the microcarriers.

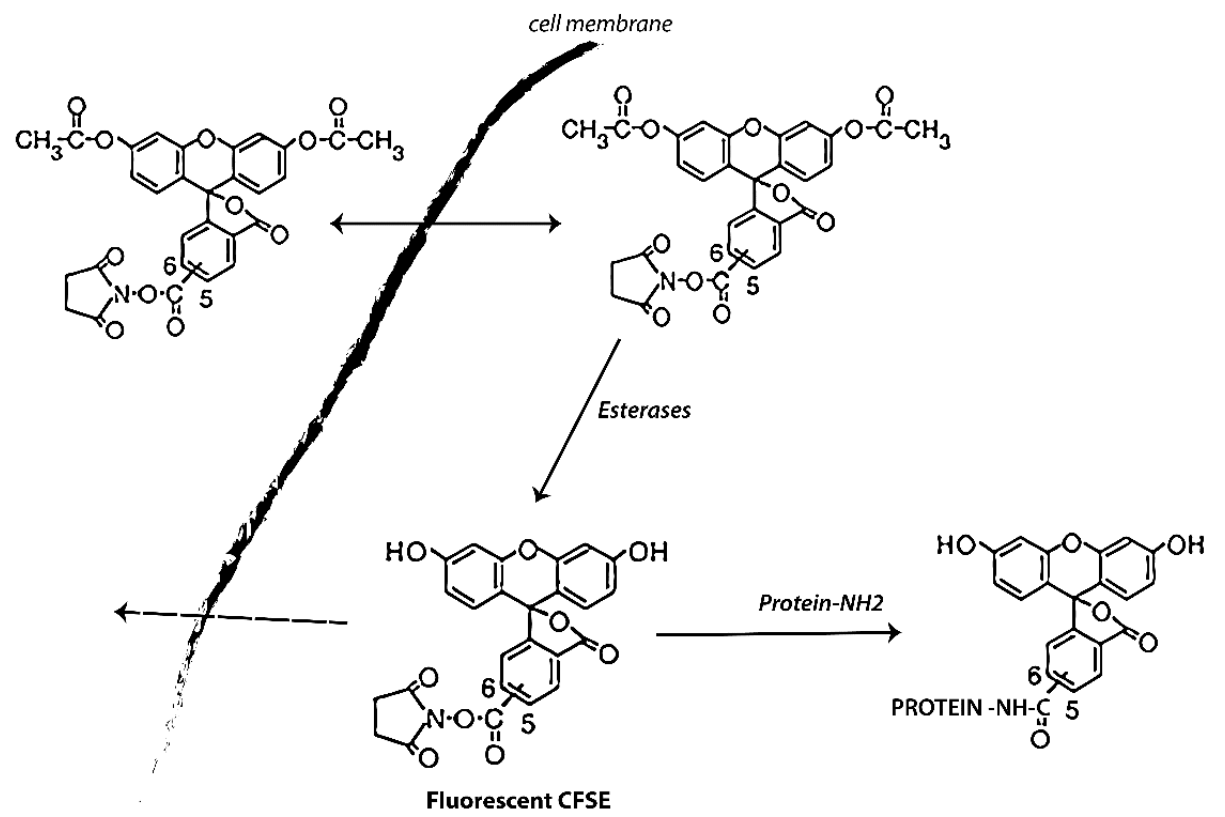

Figure 12. Schematic description of the pro-dye of CFSE that can pass freely over the cell membrane, and that after cleavage by intracellular esterases obtains the fluorescent state and upon binding to intracellular proteins is retained in the intracellular compartment. Adapted from Parish, $1999^{258}$

\section{Flow cytometry}

Flow cytometry enables simultaneous measurement and analysis of several characteristics of cells or particles using light scatter properties. Standard applications are cell counting and cell sorting as well as analyses based on 
fluorescently labelled markers of interest. Measurement of CFSE intensity with a flow cytometer was performed to establish the proliferation of the CFSE stained cells on the microcarriers and cells cultured adherently. Proliferation was investigated after 72 hours in spinner flask culture. The CFSE stain is covalently bound intracellularly and inherited at cell division as previously described. This enables proliferation measurements under the assumption that the amount of CFSE is halved at every cell division. By measuring the CFSE intensity of individual cells with a flow cytometer, populations of cells that have equal amounts of CFSE can be discerned. CFSE-stained keratinocytes and melanocytes cultured on microcarriers were detached by incubation with trypsin for five minutes at $37{ }^{\circ} \mathrm{C}$ followed by vortexing. Keratinocytes were passed through a $30 \mu \mathrm{m}$ filter and melanocytes through a $10 \mu \mathrm{m}$ filter, washed and resuspended in PBS. A control population for CFSE staining representing cells that have not divided was stained as previously described six hours before flow cytometric analyses. Adherently cultured CFSE-stained cells and six hour control cells were trypsinised, washed and resuspended in PBS. Flow cytometric measurements were performed with a Gallios flow cytometer (Beckman Coulter, Brea, CA) at $488 \mathrm{~nm}$. Data was analysed with Kaluza software (Beckman Coulter). Single cells were included in the statistical analysis and cells overlapping the CFSE intensity of the six hour control were excluded to obtain percentage of cells that had divided.

\section{Fluorescence microscopy and confocal microscopy}

In papers I and II fluorescence microscopy was used to localise antigens stained with fluorescent secondary antibodies to identify proteins present in the reepithelialised wounds. The sections were visualised with an Olympus BX41 light/fluorescence microscope. Images were captured with a DP70 CCD camera (Olympus) and overlay images were constructed in Adobe Photoshop CS5 (Adobe Systems, San Jose, CA). 
In paper I, the neoepidermis of wounds with microcarriers was investigated with confocal imaging of the cytokeratin staining. Images were captured with a Zeiss LSM 700 microscope with Zeiss ZEN software (Carl Zeiss AG, Oberkochen, Germany) and images were constructed in FIJI (230).

\section{Statistical analyses}

Statistical analyses were performed in GraphPad Prism v. 5.0 (GraphPad, La Jolla, CA). All graphs were constructed in GraphPad Prism v. 5.0. A probability level of $\leq 0.05$ was considered significant.

Paper I. Neoepidermal thickness was measured digitally and wounds with administered microcarriers were compared with control wounds without microcarriers. Means were compared using Student's t-test.

Paper II. A two-way analysis of variance (ANOVA) was performed to test significance of viability of CFSE-stained keratinocytes and melanocytes compared to non-stained control. A two-way ANOVA repeated measurements test was performed followed by Bonferroni's multiple comparisons test on the data from scratch assays on migration of CFSE-stained keratinocytes and melanocytes. The percentage of divided cells in microcarrier culture was compared with adherent control cells and groups were compared with Student's t-test.

Paper III. A Kolmogorov-Smirnov testing of the viability and migration data revealed normal distribution and groups per time point were compared with Student's t-test in both cases. Fold change in the PCR of respective groups were compared with controls cultured at normal $\mathrm{pH}$ with a Mann-Whitney U test.

Paper IV. Groups of the fifteen minute exposure experiments were compared with Student's t-test. One-way ANOVA was performed on experiments with more than 
two groups. Non-linear regression analysis of cell viability and increasing concentration of SDS was performed.

\section{Ethical considerations}

All cells used were of human origin. Primary cells were prepared from discarded full thickness skin biopsies, rescued from routine reduction plasties or abdomenoplastic surgeries. The rescue of tissue did not influence the proceeding of the surgery in any way. All tissue samples were de-identified to ensure that samples cannot be traced back to the patient to adhere to ethical guidelines concerning the use of discarded human tissue (Law 2003:46). 


\section{SUMMARY OF PAPERS}

The work presented in this thesis aimed at evaluating the use of human full thickness skin in vitro. When cultured in a maintenance medium containing $10 \%$ FCS, the skin remains viable with cells that respond to wounding cues with activation and re-epithelialisation. Moreover, intact full thickness skin exhibits a complete barrier function with all components and constituting cells present. The human in vitro wound healing model was used to study neoepidermal organisation following administration of porous gelatin scaffolds. In this setting, a novel fluorescent staining was evaluated for the tracing of transplanted cells, and to evaluate the effects of modifying the wound healing environment. Finally, the use of intact skin to study cytotoxicity responses was evaluated.

\section{Paper I: Biodegradable gelatin microcarriers facilitate re- epithelialisation of human cutaneous wounds - an in vitro study in human skin}

In previous studies published by our group, The CultiSpher-S gelatin porous microcarriers have been used to investigate suitability as a dermal scaffold and as a carrier for keratinocytes transplanted to rats $(172,174)$. In paper I, the human wound healing model was used to test the effect of providing the resident cells in the wounds with a porous, malleable gelatin scaffold. The results revealed population of the scaffold after 21 days in culture. Wound edge keratinocytes formed a thick neoepidermis (Figure 13) that stratified when cultured in the airliquid interface. The neoepidermis was analysed with regards to markers of mature epidermis: keratin 5, keratin 10, and laminin 5 (Figure $14 \mathrm{~A}$ and D) using immunohistochemical staining. Additionally, the expression of the proliferation marker nuclear antigen Ki-67 was investigated. The cytokeratin expression was found to be similar to the normal organisation of keratin 5 in the basal layers of the epidermis and keratin 10 in the superficial layers. There was no increase in the 

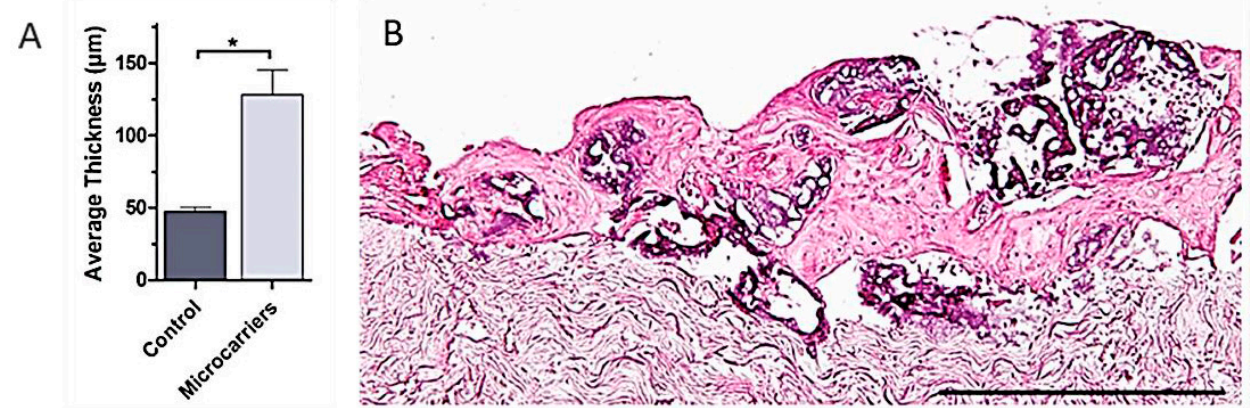

Figure 13. (A) Neoepidermal thickness after 21 days in tissue culture. Control: $47.6 \mu \mathrm{m} \pm 3.1$, with microcarriers: $128.0 \mu \mathrm{m} \pm 17.4$ (mean $\pm \mathrm{SD}$ ). (B) Haematoxylin and eosin staining of in vitro wound with incorporated microcarrier scaffold presenting a thick neoepidermis. Scale bar $=500 \mu \mathrm{m}$.
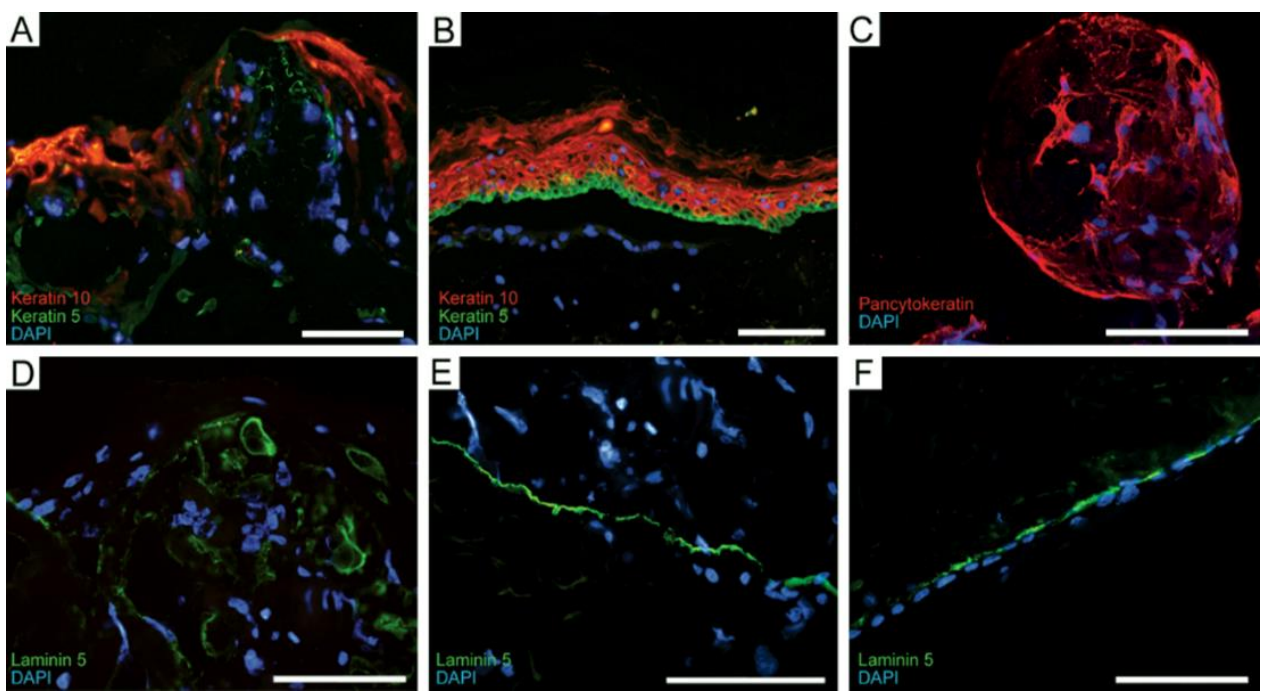

Figure 14. (A) Immunohistochemical staining against basal keratin 5 (green) and keratin 10 (red) of wound with incorporated CultiSpher-S microcarriers. (B) Immunohistochemical staining against keratin 5 (green) and keratin 10 (red) in normal unwounded skin. (C) Confocal image of microcarrier populated by keratinocytes, staining against pancytokeratin (red). (D) Immunohistochemical staining against laminin 5 (green) in wound with incorporated microcarriers, (E) normal unwounded skin and (F) control neoepidermis. Nuclear staining (blue) with 4, 6-diamidino-2-phenylindole (DAPI). Scale bars $=100 \mu \mathrm{m}$.

expression of the proliferation marker $\mathrm{Ki}-67$ at the wound edges of the experimental wounds compared with control wounds without carriers. This is 
indicative of normal proliferation rates, and that the neoepidermis is the result of migration of wound edge keratinocytes. The neoepidermis in the wounds receiving microcarriers displayed a disorganised cell orientation. However, the keratinocytes within the scaffold expressed laminin 5 (Figure $14 \mathrm{D}$ ), an important anchoring filament in the basement membrane structure. The integrin expression in keratinocytes and the distribution in the epidermis contributes to the polarity of keratinocytes (245) and the integrins are associated with laminin 5. The expression of laminin 5 by keratinocytes that are incorporated into the lower parts of the microcarrier scaffold indicates an obtained polarity in the neoepidermis.

The porosity of the CultiSpher-S microcarriers serves two main purposes: it increases the surface area for cell attachment for adherent cells, and it allows the diffusion of nutrients and oxygen throughout the entire scaffold. The effect of the porosity of the scaffold biomaterial was investigated by culturing wounds with added gelatin in solution. This revealed incomplete re-epithelialisation of experimental wounds and points to the importance of the porous structure of CultiSpher-S as a guiding cue for wound edge keratinocytes. Structure-wise the microcarriers fulfil several of the demands placed on a biomaterial aimed for regenerative purposes (246) where the ultimate goal is to use biomaterials that closely resemble and mimic the niche of the cells that are to be stimulated to regenerate a certain type of tissue. Gelatin bares high molecular resemblance to collagen, the main component of dermis. Collagen type I and III form thin collagen bundles in the papillary dermis. The lower and major part of the dermis, the reticular layer, consists of thick bundles of collagen I (247). The in vitro wounds span over the dermo-epidermal junction into the loosely packed papillary dermis. When inspecting the interface between microcarriers and the dermal wound bed, no gap or capsule formation was observed. Previous work by Huss et al. (174) showed no adverse effects when CultiSpher-S microcarriers were injected into the dermis of healthy volunteers. The microcarriers were populated with fibroblasts 
after 14 days and the gelatin degraded by 12 weeks. The microcarriers show here another important property for regenerative biomaterials: since the niche is changing over time, which certainly is true for a wound healing environment, the microcarriers can adapt to the environment yet provide an initial structural stability. If possible, a biomaterial should also support neovascularisation. This is true for the gelatin microcarriers and was shown in the study by Huss et al. where the neodermis was vascularized after 12 and 26 weeks (174). In the present study, we observed capillaries in the dermis in the vicinity of the microcarriers and no gap formation between the scaffold and the dermis. Keratinocytes had populated the complete carriers as seen by confocal imaging of microcarriers in the wounds (Figure $14 \mathrm{C}$ ). Taken together, these studies indicate that CultiSpher-S show biocompatibility and can function as a guiding scaffold for both epidermal and dermal regeneration.

\section{Conclusions and future outlook}

- Human in vitro wounds with administered microcarriers presented a thick neoepidermis with incorporation of the gelatin microcarrier scaffold

- Keratinocytes in the neoepidermis expressed keratins in a similar stratified organisation to native epidermis

- Keratinocytes within the microcarrier scaffold expressed basal membrane marker laminin 5

- The porosity of the microcarrier scaffold contributed to the organisation of the neoepidermis

- No gap formation took place in the interface between scaffold and the dermal wound bed

The in vitro wounds are cultured submerged in cell culture medium. In clinical practice acute and chronic wounds are treated under moist conditions, which has 
been extensively demonstrated to improve healing outcome. Future human studies to evaluate the beneficial properties of a porous microcarrier scaffold on wound healing need be performed to obtain relevant information of the organisation and barrier properties of the neoepidermis in an in vivo environment.

CultiSpher-S microcarriers exhibit many beneficial properties for future applications: the carriers can be topically applied or injected, they are highly biomimetic and can be loaded with cells or growth factors. The loading properties strongly contribute to the possible development of a transplantable scaffold which could mimic the natural niche of the involved cells and adapt to and stimulate the wound healing process. The CultiSpher-S are malleable and require no prefabrication steps before application to any shape of wound, and are according to our findings suitable as a tissue guiding scaffold for both epidermis and dermis.

\section{Paper II: Tracing transplanted human keratinocytes and melanocytes with carboxyfluorescein hydroxysuccinimidyl ester (CFSE) staining}

The human in vitro full thickness skin wound healing model was utilised in paper I to investigate the potential of porous gelatin microcarriers as scaffolding for resident cells. The culture of adherent cells in this type of microcarrier culture is conventionally aimed to expand cells for subsequent transplantation, and the porous structure responsible for the scaffolding effects is optimised for a large adhesion surface and therefore a large number of cells. To use the wound healing model to further investigate in vitro wound healing requires a means for tracing transplanted cells in culture. The aim of paper II was to investigate the use of carboxyfluorescein hydroxysuccinimidyl ester (CFSE) as a tracing staining for primary keratinocytes and melanocytes. Clinically, keratinocytes are transplanted when treating burns, and melanocytes when treating hypopigmentation conditions 
like vitiligo. The use of CFSE-staining has traditionally been proliferation monitoring in lymphocytes (248) and investigated with flow cytometry. We investigated viability, migration, and proliferation of CFSE-stained keratinocytes and melanocytes. We found CFSE- staining to not affect viability of either cell type. Viability of keratinocytes at the seven day time point with $5 \mu \mathrm{M}$ staining was $100.0 \% \pm 8.2$ relative to unstained control $100.0 \% \pm 7.4$. Viability of melanocytes at the same time point and concentration was $114.0 \% \pm 19.0$ relative to control $99.8 \% \pm 17.3$. CFSE has been shown to be potentially toxic and modulating surface protein conformation, which needs to be considered if surface proteins are the target of the investigations $(249,244)$ however, for primary keratinocytes and melanocytes the lowest staining concentration proposed by manufacturer was shown to be sufficient and safe. Migration was investigated with scratch assays and migration of both cell types was unaffected seen by a full repopulation of the scratched area within 24 hours. Proliferation of CFSE-stained keratinocytes and melanocytes was investigated with flow cytometric measurement, thus employing the CFSE-staining for its conventional purpose. Retained proliferation is a prerequisite for the microcarriers to be utilised clinically for transplantation since a large number of cells is required for these procedures. Proliferation rates were retained when the two cell types were cultured on microcarriers $(70.4 \% \pm 37.9$ divided cells in keratinocyte microcarrier culture compared with adherent control $88.8 \% \pm 5.4$, and $26.3 \% \pm 21.0$ compared with adherent control $20.46 \% \pm 17.2$ for melanocytes). Both keratinocytes and melanocytes showed great variability when cultured on microcarriers, with keratinocyte proliferation differing from one spinner flask culture to the other. Technical shortcomings could be the reason for the observed variability in keratinocyte cultures: the detachment of the CFSEstained cells from microcarriers with trypsin was more problematic to perform on keratinocytes than on melanocytes. This corresponds to the level of adhesion the two cell types present in adherent culture on cell culture polystyrene, where 
melanocytes are easily detachable requiring substantially less time for trypsinisation than keratinocytes. Filtration necessary for the subsequent flow cytometric measurements could also have played part in the problem of obtaining sufficient amounts of cells, and if keratinocytes were still attached to fragments of gelatin these cells would have been lost before analysis.

The CFSE-staining withstood cryosectioning procedures. Green fluorescent transplanted keratinocytes and melanocytes could be localised in tissue sections after seven, 14 and 21 days of tissue culture (Figure 15). Keratinocytes were
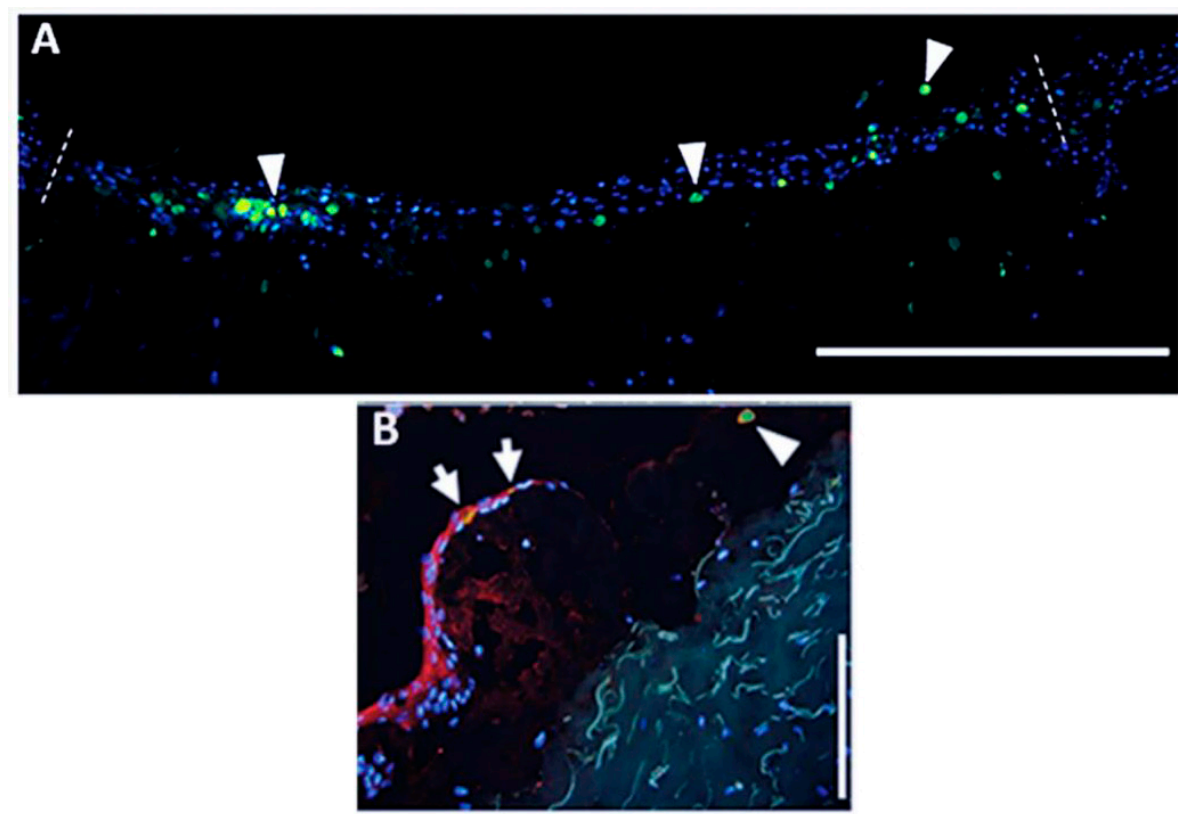

Figure 15. (A) Re-epithelialised wound after seven days of culture with carboxyfluorescein hydroxysuccinimidyl ester (CFSE) stained keratinocytes transplanted in suspension indicated by arrow heads. Dashed lines indicate wound edges. Scale bar $=500 \mu \mathrm{m}$. (B) In vitro wound at day seven of culture with transplanted CFSE-stained keratinocytes and CFSE-stained melanocytes on microcarrier scaffolds. Section stained with antibody against cytokeratin to distinguish native keratinocytes (red), transplanted double-stained keratinocytes (yellow, arrows) and transplanted melanocytes (green, arrow head). Scale bar $=$ $200 \mu \mathrm{m}$. Nuclear staining (blue) with 4, 6-diamino-2-phenylindole (DAPI). 
transplanted in suspension as well as on microcarrier scaffolds. The wounds receiving no microcarriers but CFSE-stained cells showed expected reepithelialisation times and incorporation of transplanted keratinocytes in the reepithelialised wound (Figure $15 \mathrm{~A}$ ), thus no negative effect of the staining on reepithelialisation could be observed. Co-transplantation of CFSE-stained keratinocytes and melanocytes was performed with the aid of microcarriers. Here the two transplanted cell types were distinguished from one another by immunohistochemical staining against cytokeratin and red fluorescent secondary antibody. The double stained keratinocytes could be seen in orange/yellow compared with the red stained native epidermis (Figure $15 \mathrm{~B}$ ).

The application of CFSE-staining for tracing human primary keratinocytes and melanocytes was shown to be suitable and easily applicable. The staining is readily available, easy to use and requires no custom preparation of the cells. In the present study CFSE-staining was used for tracing human primary keratinocytes and melanocytes in vitro. CFSE-stained cells have been traced in vivo in mouse (250, 251), rat (252), and pig models (253) but further studies on toxicity of CFSE for humans need to be performed before in vivo applications can be considered.

\section{Conclusions and future outlook}

- Staining of human primary keratinocytes and melanocytes with $5 \mu \mathrm{M}$ CFSE did not significantly affect viability, migration or proliferation of the cells

- Administration of CFSE-stained cells to human in vitro wounds did not affect re-epithelialisation

- The CFSE-staining can withstand cryosectioning procedures

- CFSE-stained keratinocytes and melanocytes could be traced in tissue sections from in vitro wounds to up to three weeks 
The proliferation measurement with the aid of flow cytometry of CFSE-staining is based on the dilution of the staining that occurs at every cell division. It is assumed that the fluorescence intensity is halved at every generation. CFSE fulfils several important requirements for a dye to perform with high resolution under these premises: the initial staining intensity is high, the variability of the fluorescence is low, there is minimal transfer of dye after staining and CFSE shows low toxicity for cells (254). Due to staining intensity and low variability in fluorescence, distinct peaks in fluorescence intensity can be obtained when investigating number of cell divisions with flow cytometry. In paper II we have investigated the presence of stained cells with retained fluorescent signal in tissue sections, unable to state how many cell divisions the observed cell has undergone. Measurements of staining intensity of traced cells in sections needs to be compared with newly stained cells, to be able to report number of divisions of transplanted cells that have taken place. The performance of CFSE as a staining for measuring fluorescence intensity in tissue sections needs to be evaluated. The application of CFSE-staining on human primary epidermal cells could be a valuable tool for investigating transplantation and the fate of transplanted cells owing to its simple processing, stable fluorescence and low impact on human primary keratinocytes and melanocytes.

\section{Paper III: Influence of acidic $\mathrm{pH}$ on keratinocyte function and re- epithelialisation of in vitro wounds}

Adjuvant therapies for modifying the wound healing environment and therefore hopefully aiding chronic wound healing include laser and ultrasound therapy, electrical stimulation, and treatment with hyperbaric oxygen, negative pressure therapy (255) and $\mathrm{pH}$ modulation (256). None of the treatment approaches have been shown to conclusively contribute to improved healing though negative pressure therapy has been extensively used in the clinical setting (257). Few 
investigative reports are available on the impact on lowering wound $\mathrm{pH}$ on wound healing (258). The rationale behind the lowering of $\mathrm{pH}$ in the wound environment stems from the facts that intact skin is slightly acidic and that when wound healing proceeds, a slight acidosis takes place. Several proteases and bacteria are active in basic milieus, and chronic wounds display elevated $\mathrm{pH}$ levels that could contribute to the unfavourable wound healing environment present in chronic wounds (256). The aim of paper III was to utilise the in vitro wound healing model to investigate re-epithelialisation of in vitro wounds exposed to $\mathrm{pH} 5.0$ and $\mathrm{pH} 6.0$, and the effects on primary human keratinocytes in culture exposed to the lowered $\mathrm{pH}$ levels with functional assays and qRT-PCR.

In vitro wounds were cultured submerged in FM with $10 \%$ FCS adjusted to $\mathrm{pH}$ 5.0 and $\mathrm{pH} 6.0$ with $1 \mathrm{M}$ hydrochloric acid. Wounds cultured at $\mathrm{pH} 5.0$ showed no re-epithelialisation at any time point. Wounds and biopsy edges of wounds cultured at pH 6.0 showed moderate outgrowth compared with control wounds cultured at pH 7.4 (Figure 16 A, B and D). The findings in the functional assays were supportive of the tissue culture results where the responses of keratinocytes cultured at $\mathrm{pH} 5.0$ to activation and migration cues were lost. These responses were partially retained in keratinocytes cultured at $\mathrm{pH} 6.0$ represented by moderate reepithelialisation of in vitro wounds.

Scratch assays revealed keratinocytes exposed to $\mathrm{pH} 6.0$ to be able to repopulate the scratched area up to $80 \%$ after 24 hours compared with no migration taking place in the cultures exposed to $\mathrm{pH} 5.0$ (Figure 17). Reflected in the viability measurements where viability in the $\mathrm{pH} 5.0$ culture was beneath $50 \%$ of the normal controls at all time points, the poor migration was expected.

The qRT-PCR revealed differential expression of the investigated mRNA. The detrimental effect of pH 5.0 and the low RNA yields it resulted in, limited the time of exposure to lowered $\mathrm{pH}$ to six hours. Genes of interest were matrix 


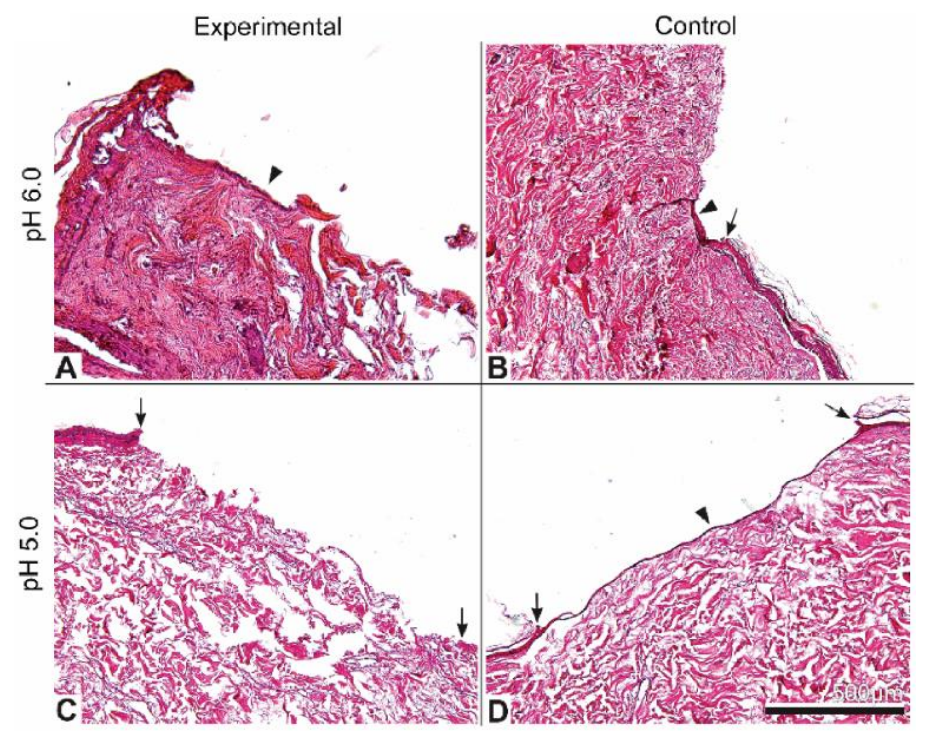

Figure 16. Haematoxylin and eosin staining of in vitro wound sections. (A) Neoepidermal outgrowth of wound cultured at $\mathrm{pH} 6.0$ for eight days and (B) control wound at day four. (C) Wound edges of wound exposed to $\mathrm{pH} 5.0$ with no outgrowth compared with (D) fully re-epithelialised control wound at day 12 . Arrows indicate wound edges, arrow heads neoepidermal outgrowth. Scale bar = $500 \mu \mathrm{m}$.

metalloproteinase 1 (MMP1), tissue inhibitor of matrix metalloproteinase 1 (TIMP1) (259), protein kinase 2 (PTK2) and heat shock $27 \mathrm{kDa}$ protein 1 (HSPB1). HSPB1 is also known as HSP27, heat shock protein 27, and is a cytoprotective protein that localises to the nucleus when cells are stress induced and is involved in avoiding apoptosis, and actin network rearrangement (260). QRT-PCR showed upregulation of HSPB1 in cells exposed to $\mathrm{pH}$ 6.0. This could partly account for the retained capacity to migrate by the cells exposed to $\mathrm{pH} 6.0$ which was seen in the scratch assay, coupled to the upregulation of PTK2 that was also revealed by the qRT-PCR. PTK2 (also known as FAK, focal adhesion kinase) binds the activated cytoplasmic tail of plasma membrane integrins (261) and is the mediator in several important pathways (262) wherein migration and adhesion in response to cues from the ECM through integrins are well charted (263). Capacity to migrate 
at $\mathrm{pH} 6.0$ is of importance if acidification is to be applied as a treatment strategy. However, values of the qRT-PCR present substantial variance but the results indicate upregulation of both PTK2 and HSPB1.

Keratinocytes cultured at $\mathrm{pH} 6.0$ showed higher viability, an $80 \%$ coverage of

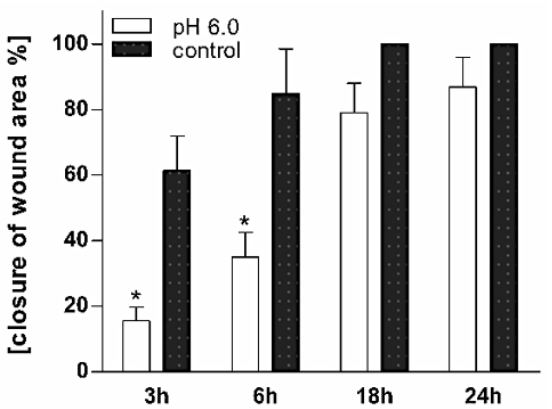
scratched area in the scratch assay, upregulation of HSPB1 and less aberrant expression of the junctional protein ZO-1 than keratinocytes cultured at $\mathrm{pH} 5.0$, with a pattern of loss of response in cells at $\mathrm{pH}$ 5.0 and a recovery and adaptation of cells to the environment at $\mathrm{pH}$ 6.0. Considering the demanding environment $\mathrm{pH} \quad 5.0$ imposes the findings of poor cell function at $\mathrm{pH} 5.0$ were expected, however the recovery of migration at $\mathrm{pH} 6.0$ shows that keratinocytes under these conditions are responsive to cues from the environment to

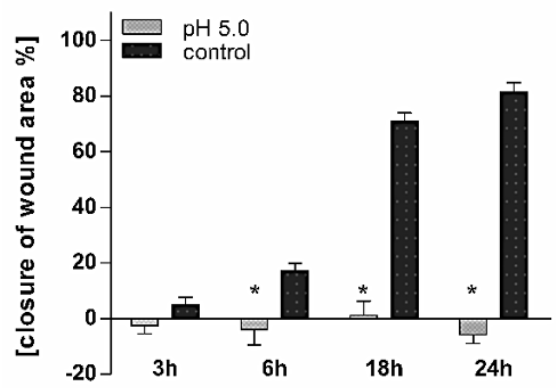

Figure 17. Scratch assay performed on keratinocytes exposed to $\mathrm{pH} 6.0$ and $\mathrm{pH}$ 5.0. At 18 hours keratinocytes cultured at pH 6.0 repopulated the scratched area to $80 \%$, no migration could be observed in cultures cultured at pH 5.0.

migrate.

\section{Conclusions and future outlook}

- No re-epithelialisation of in vitro wounds occurred under exposure to $\mathrm{pH}$ 5.0 compared to a minor outgrowth of an epithelial tongue in wounds cultured at $\mathrm{pH} 6.0$

- Keratinocytes exposed to $\mathrm{pH} 6.0$ upregulated the cytoprotective protein HSPB1 and PTK2, important for migration 
- Keratinocytes exposed to $\mathrm{pH} 6.0$ in culture showed retained capacity to migrate compared with keratinocytes exposed to $\mathrm{pH} 5.0$

Lowering the $\mathrm{pH}$ levels in the chronic wound is a relevant strategy to inhibit detrimental proteases active at high $\mathrm{pH}$ levels (264). In attempt to mimic the natural state of the wound, acidification could be beneficial for chronic wound environments that have stagnated in the inflammatory phase. According to our findings on keratinocyte function and re-epithelialisation of in vitro wounds exposed to $\mathrm{pH} 5.0$ and 6.0 we conclude that lowering the $\mathrm{pH}$ in the wound environment below pH 6.0 is inadvisable due to the severely impaired function of keratinocytes at $\mathrm{pH}$ 5.0. The wound environment $\mathrm{pH}$ levels should be taken into account when choosing dressings for treatment of chronic wounds in regard to permeability of the dressing. Non-permeable dressings retain gases in the wound, including $\mathrm{CO}_{2}$. The $\mathrm{CO}_{2}$ will contribute to acidification of the wound whereas permeable dressings like hydrogel dressings permit gas exchange and can contribute to maintaining $\mathrm{pH}$ levels in the wound healing environment suitable for re-epithelialisation.

\section{Paper IV: Non-occlusive topical exposure of human skin in vitro as model for cytotoxicity testing of irritant compounds}

In paper IV, human full thickness skin was utilised to investigate cytotoxicity in skin when exposed to a known irritant. The aim was to elucidate whether intact skin with a fully functional barrier could be used to model the response. Irritants are difficult to test: the use of animals should be restricted from an ethical stand point, the Draize test has been challenged over the years. Moreover, the signs of irritation visible to the subjective investigator include erythema, oedema and spongiosis that are difficult to discern (265). This limits the use of human subjects where only a certain degree of discomfort is acceptable. 
The first 15 minute exposure tests, which is standard testing time for short exposure, on intact human skin in vitro were carried out with PBS as negative control substance and SDS, the known irritant, diluted in PBS. The variance in response to PBS was found to be substantial and therefore PBS as control substance was changed to non-supplemented DMEM. The viability values obtained from the negative controls with DMEM were more stable, and long term (six hour) exposure experiments were carried out with DMEM as control and solvent. Non-linear regression analysis revealed an $\mathrm{R}^{2}=0.76$ between increased concentration of SDS and decreased viability of keratinocytes in the exposed area. The exposure of intact skin to $2 \%$ SDS only elicited a modest cytotoxic response (Figure $18 \mathrm{~A}$ and B). This points out the problems that arise when skin equivalents are used for cytotoxicity testing: the lack of full barrier protection of the skin equivalent models carries an over-prediction when testing irritants. There are several reconstituted human skin models, out of which EPISKIN (Episkin SNC, Chaponost, France) and EpiDerm (MatTek Corporation, Ashland, MA) are the most used (266). In early validation studies of the models the over-prediction rates were between $47 \%$ and $60 \%$, even if accuracy rates were acceptable (267). The reconstituted skin models are based on normal human keratinocytes cultured on a collagen matrix and stratified by culturing in the air-liquid interface. The epidermal component of both systems is histologically similar to native epidermis but the models lack in barrier structure and a complete dermal component. The barrier capacity fails to reach the level of that of native tissue, and additionally all interaction between keratinocytes and fibroblasts. Native target tissue is preferable and there is a real possibility to use it in the case of human skin. In the presented model, tissue is viable and includes all cells present in the skin except homed immune cells (268). Most importantly the barrier components of stratum corneum, tight junction seals, an intact basement membrane and dermal cells are all present. 


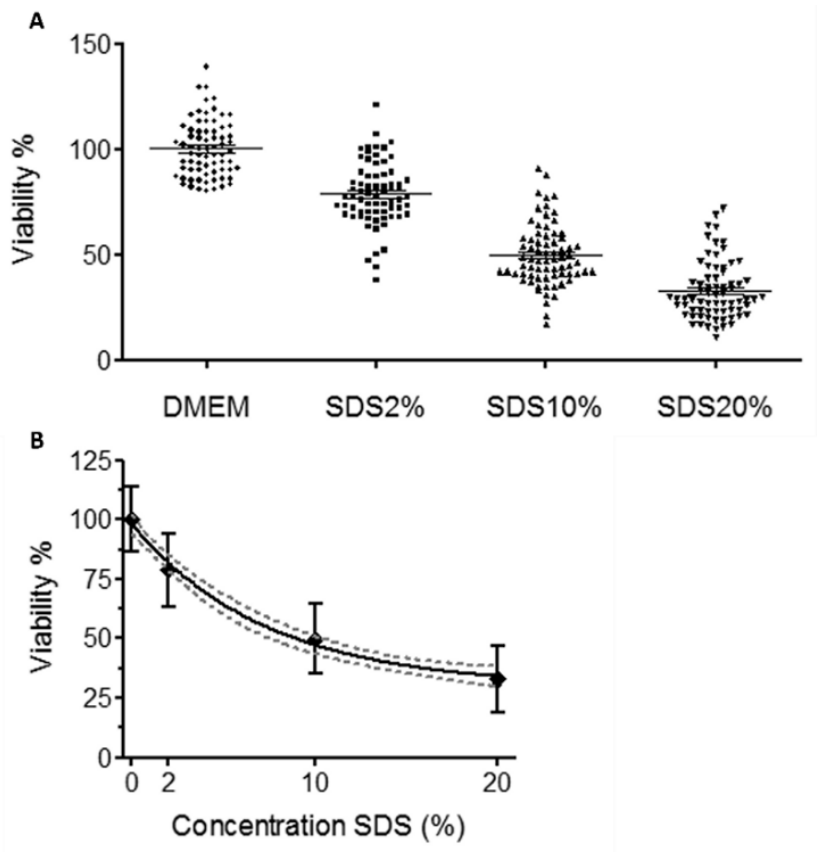

Figure 18. (A) Distribution of viability values of all six hour exposure experiments with full thickness skin exposed to $2 \%, 10 \%$ and $20 \%$ sodium dodecyl sulphate (SDS). Viability values are relative to control Dulbecco's modified Eagle medium (DMEM). All group means differ significantly from control DMEM (mean $\pm \mathrm{SD}$, $\mathrm{n}=72$ ). (B) Non-linear regression analysis of increased concentration of SDS and decreased viability, $\mathrm{R}^{2}=0.76$.

The foremost objection to using human skin in culture for testing of irritant potential is the inherent interpersonal variability. To counteract this, every experiment was performed on one skin sample. The irritant response measured by cytotoxicity was related to an internal positive control at all times. The positive control was $20 \%$ SDS in DMEM. SDS is one of the most utilised known irritants in irritant testing, and $20 \%$ is a frequently used concentration to elicit an irritant reaction (269). The reaction was then related to a negative control to obtain information on irritant potential, and also relate the investigated compound/concentration to the positive control to ensure the level of irritation the investigated compound evokes. In the application of human full thickness skin for 
irritant testing cytotoxicity was chosen as parameter to investigate. It is a quantifiable parameter that directly reflects the damage to the keratinocytes. Disturbance of keratinocytes also initiates the subsequent events that lead to the manifestation of irritation by causing release of stored IL- $1 \alpha$ from the keratinocytes. A limitation of using human skin in vitro, or any other in vitro model, is the lack of circulation and a systemic response. However, a limited immune response in human skin in vitro is present in the form of stochastic presence of immune cells. Compared to reconstituted skin models this is still an advantage that the full thickness skin presents. By limiting the exposure to only topical the entry route of the investigated substance is the same that would occur in a real life situation and the immune activation starts with the release of cytokines from disrupted keratinocytes. The interaction of keratinocytes with melanocytes and dermal fibroblasts can take place in a model of full thickness skin, and the release of cytokines by keratinocytes and the subsequent effects on fibroblasts is of interest to develop the human full thickness irritation model further.

\section{Conclusions and future outlook}

- Viability staining of skin samples topically exposed to irritant yielded stable responses with non-supplemented Dulbecco's modified Eagle medium as negative control substance

- Non-linear regression analysis revealed $\mathrm{R}^{2}=0.76$ between increased concentration of known irritant sodium dodecyl sulphate and decreased cell viability in the exposed areas

Many different approaches for toxicity testing are being developed to replace the use of animals. The next step in any development of a new methodology is the validation of the model. This includes systematic testing with known reference chemicals to determine the accuracy of the model and the intra- and inter 
laboratory variability. The validation process should also establish the suitability of the model to test different classes of chemicals. The use of viable human skin as presented in paper IV needs to be validated to adhere to regulatory settings.

In the present study the means of exposure of the human full thickness skin was non-occluded, a mode of application that cannot easily be performed on human subjects. The presented model can be modified to investigate occluded exposure as well as repeated exposures. Repeated and occluded exposures are both relevant problem formulations for occupational hazard investigations. Human full thickness skin can be kept in culture for several weeks which enables the model to be utilised for long term exposures, another exposure scheme that is problematic to perform on human volunteers. Additionally, human skin in vitro can be predisposed, with e.g. water exposure, or abraded to investigate more specific question formulations where the quality of skin plays a part. The proposed model can be easily modified to provide more insight in irritant cytotoxicity in human skin. 


\section{CONCLUDING REMARKS}

The work presented within this thesis has focused on applications of human full thickness skin in vitro. Human skin in vitro presents an adequate response to wounding visualised by the re-epithelialisation of standardised wounds and possesses a fully functional cutaneous barrier. Representative model systems for any physiological or pathological process is a necessity for relevant research focus and translational success. In the case of cutaneous wound healing, the need for a modelling system that takes into account the reciprocal interactions that take place during the complex process is crucial, as re-epithelialisation is highly dependent on extracellular matrix cues and fibroblast interaction. Investigations on wound healing and irritant response employing human skin in vitro makes use of the actual target tissue with all constituting cell types and matrix components present. 


\section{ACKNOWLEDGEMENTS}

I would like to extend a sincere thank you to the following persons who have contributed to this thesis and supported my work:

My main supervisor Gunnar Kratz, for giving me the opportunity to work with you and the freedom to develop, for the encouragement and all the lessons on positive thinking.

My co-supervisor Magnus Berggren, for introducing me to the world of organic electronics and the people working in your group, your professionalism is truly inspiring.

Jonathan Rakar my colleague, supervisor, collaborator and friend, for all work you have done and all support (both IT and mental) you have provided over these years.

Kristina Briheim for teaching me all I know and more about cell and tissue culture, and for being a stand in parent.

All members of the plastic surgery lab I have had the pleasure to meet and work with over the years, Johan Junker for supervision, introduction to coffee induced science, and proof reading, Anita Lönn for all assistance and introduction to teaching, Pehr Sommar and Lisa Karlsson for collaborations, Maria Karlsson for contribution to paper II.

Kristin Persson, David Nilsson, Anurak Sawatdee, Henrik Toss, Josefin Nissa \& Daniel Simon at the Laboratory of Organic Electronics, for interesting and challenging collaborations.

Stefan Klintström, Charlotte Immerstrand \& Anette Svensson of Forum Scientium for inspirational study visits.

Everyone at KEF for creating a nice place to work, Stina \& Tove who paved the way, Sebastian \& Cynthia for the good times, after works and proof reading. Micke Pihl at the Flow facility for first suggesting CFSE and help with flow cytometry. Håkan Wiktander and Åsa Schippert \& Anette Molbaek at Core facility for help with really everything. 
Linda, Pilvi, Vivi \& Linda, Anna, Katarina for being part of the home to come home to.

Jonas, Anders, Jocke \& Sandra, Joanne \& Ryan my beloved dysfunctional family!

Sofie, Linnea \& Cici for excellent peer support and invaluable friendship.

Äiti, Linda \& Pappa for never questioning and always supporting.

Johannes there is no one whose opinion or advice I value higher, it is all for you! 


\section{REFERENCES}

1.

Matsui T, Amagai M.

Dissecting the formation, structure and barrier function of the stratum corneum. Int Immunol.27(6):26980.

2. Compton CC, Nadire KB, Regauer S, Simon M, Warland G, O'Connor NE, et al. Cultured human sole-derived keratinocyte grafts re-express site-specific differentiation after transplantation. Differentiation; research in biological diversity. 1998;64(1):45-53.

3. Haftek M. 'Memory' of the stratum corneum: exploration of the epidermis' past. Br J Dermatol.171 Suppl 3:6-9.

4. Loschke F, Seltmann $\mathrm{K}$, Bouameur JE, Magin TM. Regulation of keratin network organization. Current opinion in cell biology. 2015;32:56-64.

5. Freedberg IM, TomicCanic $\mathrm{M}$, Komine $\mathrm{M}$, Blumenberg $\mathrm{M}$. Keratins and the keratinocyte activation cycle. The Journal of investigative dermatology. 2001;116(5):633-40.

$6 . \quad$ Walko G, Castanon MJ, Wiche G. Molecular architecture and function of the hemidesmosome. Cell and tissue research. 2015;360(3):529-44.

7. Huber O, Petersen I.

150th Anniversary Series:

Desmosomes and the Hallmarks of
Cancer. Cell communication \& adhesion. 2015;22(1):15-28.

8.

Loschke F, Homberg

M, Magin TM. Keratin Isotypes

Control Desmosome Stability and

Dynamics through PKCalpha. The Journal of investigative dermatology. 2015.

9.

Kirschner N, Houdek

P, Fromm M, Moll I, Brandner JM.

Tight junctions form a barrier in human epidermis. European journal of cell biology. 2010;89(11):839-42.

10.

Kirschner $\mathrm{N}$,

Rosenthal R, Furuse M, Moll I, Fromm M, Brandner JM.

Contribution of tight junction proteins to ion, macromolecule, and water barrier in keratinocytes. The Journal of investigative dermatology. 2013;133(5):1161-9.

11. Kirschner N, Brandner JM. Barriers and more: functions of tight junction proteins in the skin. Ann N Y Acad Sci. 2012;1257:158-66.

$12 . \quad$ Furuse $M$, Hata $M$, Furuse K, Yoshida Y, Haratake A, Sugitani $Y$, et al. Claudin-based tight junctions are crucial for the mammalian epidermal barrier: a lesson from claudin-1-deficient mice. The Journal of cell biology. 2002;156(6):1099-111.

13.

Hirao T, Denda M, Takahashi M. Identification of immature cornified envelopes in 
the barrier-impaired epidermis by characterization of their hydrophobicity and antigenicities of the components. Experimental dermatology. 2001;10(1):35-44.

14.

Eckhart L, Lippens S, Tschachler E, Declercq W. Cell death by cornification. Biochimica et biophysica acta.1833(12):347180.

15. Kezic S, O'Regan GM, Lutter R, Jakasa I, Koster ES, Saunders $S$, et al. Filaggrin loss-offunction mutations are associated with enhanced expression of IL-1 cytokines in the stratum corneum of patients with atopic dermatitis and in a murine model of filaggrin deficiency. The Journal of allergy and clinical immunology. 2012;129(4):1031-9 e1.

16. Tu CL, Bikle DD. Role of the calcium-sensing receptor in calcium regulation of epidermal differentiation and function. Best Pract Res Clin Endocrinol Metab. 2013;27(3):415-27.

$17 . \quad$ Boyce ST, Ham RG. Calcium-regulated differentiation of normal human epidermal keratinocytes in chemically defined clonal culture and serum-free serial culture. The Journal of investigative dermatology. 1983;81(1 Suppl):33s40 s.

18.

Candi E, Schmidt R, Melino G. The cornified envelope: a model of cell death in the skin.
Nature reviews Molecular cell biology. 2005;6(4):328-40.

19. Janes SM, Ofstad TA, Campbell DH, Eddaoudi A, Warnes G, Davies D, et al. PI3-kinasedependent activation of apoptotic machinery occurs on commitment of epidermal keratinocytes to terminal differentiation. Cell Res. 2009;19(3):328-39.

20. Ishida-Yamamoto A, Kishibe M. Involvement of corneodesmosome degradation and lamellar granule transportation in the desquamation process. Med Mol Morphol. 2011;44(1):1-6.

21.

Chapman SJ, Walsh

A. Desmosomes, corneosomes and desquamation. An ultrastructural study of adult pig epidermis. Archives for dermatological research $=$ Archiv fur dermatologische Forschung. 1990;282(5):304-10.

$22 . \quad$ Fischer J, MeyerHoffert U. Regulation of kallikreinrelated peptidases in the skin - from physiology to diseases to therapeutic options. Thrombosis and haemostasis. 2013;110(3):4429.

23. Borgono CA, Michael

IP, Komatsu N, Jayakumar A, Kapadia R, Clayman GL, et al. A potential role for multiple tissue kallikrein serine proteases in epidermal desquamation. The Journal of biological chemistry. 2007;282(6):3640-52. 
24.

Tsatmali M, Ancans J,

Thody AJ. Melanocyte function and its control by melanocortin peptides. J Histochem Cytochem. 2002;50(2):125-33.

25. Thingnes J, Lavelle TJ, Hovig E, Omholt SW. Understanding the melanocyte distribution in human epidermis: an agent-based computational model approach. PloS one. 2012;7(7):e40377.

26. Seiberg $\mathrm{M}$.

Keratinocyte-melanocyte interactions during melanosome transfer. Pigment cell research / sponsored by the European Society for Pigment Cell Research and the International Pigment Cell Society. 2001;14(4):236-42.

27.

Kippenberger $\mathrm{S}$,

Bernd A, Bereiter-Hahn J, Ramirez-

Bosca A, Kaufmann R. The mechanism of melanocyte dendrite formation: the impact of differentiating keratinocytes. Pigment cell research / sponsored by the European Society for Pigment Cell Research and the International Pigment Cell Society. 1998;11(1):34-7.

28. Ando $\mathrm{H}$, Niki $\mathrm{Y}$, Ito $\mathrm{M}$, Akiyama K, Matsui MS, Yarosh DB, et al. Melanosomes are transferred from melanocytes to keratinocytes through the processes of packaging, release, uptake, and dispersion. The Journal of investigative dermatology. 2012;132(4):1222-9.
29. Clausen BE, Stoitzner

P. Functional Specialization of Skin Dendritic Cell Subsets in Regulating T Cell Responses. Frontiers in immunology. 2015;6:534.

30.

Maksimovic S, Nakatani M, Baba Y, Nelson AM, Marshall KL, Wellnitz SA, et al. Epidermal Merkel cells are mechanosensory cells that tune mammalian touch receptors. Nature. 2014;509(7502):617-21. 31. Maricich SM, Wellnitz SA, Nelson AM, Lesniak DR, Gerling GJ, Lumpkin EA, et al. Merkel cells are essential for lighttouch responses. Science. 2009;324(5934):1580-2.

32. Gelse K, Poschl E, Aigner T. Collagens--structure, function, and biosynthesis. Adv Drug Deliv Rev. 2003;55(12):153146.

33. Fleischmajer $\mathrm{R}$, MacDonald ED, Perlish JS, Burgeson RE, Fisher LW. Dermal collagen fibrils are hybrids of type I and type III collagen molecules. Journal of structural biology. 1990;105(13):162-9.

34. Kielty CM, Sherratt MJ, Shuttleworth CA. Elastic fibres. Journal of cell science. 2002;115(Pt 14):2817-28.

$35 . \quad$ Bachman $\mathrm{H}$, Nicosia

J, Dysart M, Barker TH. Utilizing Fibronectin Integrin-Binding Specificity to Control Cellular 
Responses. Advances in wound care. 2015;4(8):501-11.

36.

Potts JR, Campbell

ID. Structure and function of fibronectin modules. Matrix biology : journal of the International Society for Matrix Biology. 1996;15(5):31320; discussion 21.

37.

Kim SH, Turnbull J,

Guimond S. Extracellular matrix and cell signalling: the dynamic cooperation of integrin, proteoglycan and growth factor receptor. The Journal of endocrinology.209(2):139-51.

38.

Alam N, Goel HL, Zarif MJ, Butterfield JE, Perkins HM, Sansoucy BG, et al. The integringrowth factor receptor duet. Journal of cellular physiology. 2007;213(3):649-53.

$39 . \quad$ Eckes B, Nischt R, Krieg T. Cell-matrix interactions in dermal repair and scarring. Fibrogenesis \& tissue repair.3:4. 40. Carrino DA, Sorrell JM, Caplan Al. Age-related changes in the proteoglycans of human skin. Archives of biochemistry and biophysics. 2000;373(1):91-101. 41. Vega JA, Haro JJ, Del Valle ME. Immunohistochemistry of human cutaneous Meissner and pacinian corpuscles. Microscopy research and technique. 1996;34(4):351-61.

42. Moll I, Roessler M, Brandner JM, Eispert AC, Houdek P,
Moll R. Human Merkel cells-aspects of cell biology, distribution and functions. European journal of cell biology. 2005;84(2-3):259-71.

43.

Cotsarelis G.

Epithelial stem cells: a

folliculocentric view. The Journal of investigative dermatology. 2006;126(7):1459-68.

44.

Ito $M$, Liu Y, Yang Z, Nguyen J, Liang F, Morris RJ, et al. Stem cells in the hair follicle bulge contribute to wound repair but not to homeostasis of the epidermis. Nat Med. 2005;11(12):1351-4. 45. Breitkreutz D, Koxholt I, Thiemann K, Nischt R. Skin basement membrane: the foundation of epidermal integrity-BM functions and diverse roles of bridging molecules nidogen and perlecan. BioMed research international. 2013;2013:179784.

46.

Nishiyama T, Amano

$\mathrm{S}$, Tsunenaga M, Kadoya K, Takeda A, Adachi E, et al. The importance of laminin 5 in the dermalepidermal basement membrane. Journal of dermatological science. 2000;24 Suppl 1:S51-9.

47. Burgeson RE, Christiano AM. The dermalepidermal junction. Curr Opin Cell Biol. 1997;9(5):651-8.

$48 . \quad$ Dowling J, Yu QC, Fuchs E. Beta4 integrin is required for hemidesmosome formation, cell adhesion and cell survival. The 
Journal of cell biology.

1996;134(2):559-72.

49.

Aumailley $\mathrm{M}$,

Bruckner-Tuderman L, Carter WG, Deutzmann R, Edgar D, Ekblom P, et al. A simplified laminin nomenclature. Matrix biology : journal of the International Society for Matrix Biology. 2005;24(5):32632.

50. Ghohestani RF, Li K,

Rousselle $\mathrm{P}$, Uitto J. Molecular organization of the cutaneous basement membrane zone. Clinics in dermatology. 2001;19(5):551-62.

51. Gurtner GC, Werner

$\mathrm{S}$, Barrandon $\mathrm{Y}$, Longaker MT. Wound repair and regeneration. Nature. 2008;453(7193):314-21. 52. Nami N, Feci L, Napoliello L, Giordano A, Lorenzini $S$, Galeazzi M, et al. Crosstalk between platelets and PBMC: New evidence in wound healing. Platelets. 2015:1-6.

53. Clark RA. Regulation of fibroplasia in cutaneous wound repair. The American journal of the medical sciences. 1993;306(1):42-8. 54. Pierce GF, Mustoe TA, Lingelbach J, Masakowski VR, Griffin GL, Senior RM, et al. Plateletderived growth factor and transforming growth factor-beta enhance tissue repair activities by unique mechanisms. The Journal of cell biology. 1989;109(1):429-40.
55. Koh TJ, DiPietro LA. Inflammation and wound healing: the role of the macrophage. Expert reviews in molecular medicine. 2011;13:e23.

56. Majno G, Gabbiani G, Hirschel BJ, Ryan GB, Statkov PR. Contraction of granulation tissue in vitro: similarity to smooth muscle. Science. 1971;173(3996):548-50.

57. Clark RA, Lanigan JM, DellaPelle P, Manseau E, Dvorak HF, Colvin RB. Fibronectin and fibrin provide a provisional matrix for epidermal cell migration during wound reepithelialization. The Journal of investigative dermatology. 1982;79(5):264-9.

58. Singer AJ, Clark RA. Cutaneous wound healing. N Engl J Med. 1999;341(10):738-46.

59.

Krawczyk WS. A pattern of epidermal cell migration during wound healing. The Journal of cell biology. 1971;49(2):247-63. 60. Smoller BR, Krueger J, McNutt NS, Hsu A. "Activated" keratinocyte phenotype is unifying feature in conditions which predispose to squamous cell carcinoma of the skin. Modern pathology : an official journal of the United States and Canadian Academy of Pathology, Inc. 1990;3(2):171-5.

61. Herro R, Antunes Rda $\mathrm{S}$, Aguilera AR, Tamada K, Croft M. The Tumor Necrosis Factor Superfamily Molecule LIGHT 
Promotes Keratinocyte Activity and Skin Fibrosis. The Journal of investigative dermatology. 2015;135(8):2109-18.

$62 . \quad$ Coulombe PA, Bravo NS, Paladini RD, Nguyen D, Takahashi K. Overexpression of human keratin 16 produces a distinct skin phenotype in transgenic mouse skin. Biochem Cell Biol. 1995;73(9-10):611-8.

$63 . \quad$ Paladini RD, Takahashi K, Bravo NS, Coulombe PA. Onset of re-epithelialization after skin injury correlates with a reorganization of keratin filaments in wound edge keratinocytes: defining a potential role for keratin 16. The Journal of cell biology. 1996;132(3):381-97.

64. Grinnell F. Wound repair, keratinocyte activation and integrin modulation. Journal of cell science. 1992;101 ( Pt 1):1-5.

65.

Nylander-Lundqvist

E, Back O, Egelrud T. IL-1 beta activation in human epidermis. Journal of immunology. 1996;157(4):1699-704.

66. Hu Y, Liang D, Li X, Liu $\mathrm{HH}$, Zhang $X$, Zheng $M$, et al. The role of interleukin-1 in wound biology. Part II: In vivo and human translational studies. Anesthesia and analgesia. 2010;111(6):153442.

67. Kupper TS, Groves RW. The interleukin-1 axis and cutaneous inflammation. The
Journal of investigative dermatology. 1995;105(1 Suppl):62S-6S.

68. Barker JN, Mitra RS, Griffiths CE, Dixit VM, Nickoloff BJ. Keratinocytes as initiators of inflammation. Lancet. 1991;337(8735):211-4.

69. Kupper TS, Lee F, Birchall N, Clark S, Dower S. Interleukin 1 binds to specific receptors on human keratinocytes and induces granulocyte macrophage colony-stimulating factor mRNA and protein. A potential autocrine role for interleukin 1 in epidermis. The Journal of clinical investigation. 1988;82(5):1787-92.

$70 . \quad$ Komine M, Rao LS, Kaneko T, Tomic-Canic M, Tamaki K, Freedberg IM, et al. Inflammatory versus proliferative processes in epidermis. Tumor necrosis factor alpha induces $\mathrm{K} 6 \mathrm{~b}$ keratin synthesis through a transcriptional complex containing NFkappa B and C/EBPbeta. The Journal of biological chemistry. 2000;275(41):32077-88.

71. Kaur S, Zilmer K, Leping V, Zilmer M. Allergic contact dermatitis is associated with significant oxidative stress. Dermatology research and practice. 2014;2014:415638.

72.

Kutsch CL, Norris DA, Arend WP. Tumor necrosis factoralpha induces interleukin-1 alpha and interleukin-1 receptor 
antagonist production by cultured human keratinocytes. The Journal of investigative dermatology. 1993;101(1):79-85.

$73 . \quad$ Saarialho-Kere UK, Kovacs SO, Pentland AP, Olerud JE, Welgus HG, Parks WC. Cell-matrix interactions modulate interstitial collagenase expression by human keratinocytes actively involved in wound healing. The Journal of clinical investigation. 1993;92(6):2858-66.

$74 . \quad$ Pilcher BK, Dumin JA, Sudbeck BD, Krane SM, Welgus HG, Parks WC. The activity of collagenase-1 is required for keratinocyte migration on a type I collagen matrix. The Journal of cell biology. 1997;137(6):1445-57. $75 . \quad$ Sudbeck BD, Pilcher BK, Welgus HG, Parks WC. Induction and repression of collagenase-1 by keratinocytes is controlled by distinct components of different extracellular matrix compartments. The Journal of biological chemistry. 1997;272(35):22103-10.

76.

Frazier K, Williams S,

Kothapalli D, Klapper H, Grotendorst GR. Stimulation of fibroblast cell growth, matrix production, and granulation tissue formation by connective tissue growth factor. The Journal of investigative dermatology. 1996;107(3):404-11.

77. Velazquez OC. Angiogenesis and vasculogenesis: inducing the growth of new blood vessels and wound healing by stimulation of bone marrowderived progenitor cell mobilization and homing. Journal of vascular surgery. 2007;45 Suppl A:A39-47.

78. Eming SA, Brachvogel B, Odorisio T, Koch M. Regulation of angiogenesis: wound healing as a model. Prog Histochem Cytochem. 2007;42(3):115-70.

79. Hunt TK, Knighton DR, Thakral KK, Goodson WH, 3rd, Andrews WS. Studies on inflammation and wound healing: angiogenesis and collagen synthesis stimulated in vivo by resident and activated wound macrophages. Surgery. 1984;96(1):48-54.

80. Doillon CJ, Dunn MG, Bender E, Silver FH. Collagen fiber formation in repair tissue: development of strength and toughness. Collagen and related research. 1985;5(6):481-92.

81. Bonnekoh B, Huerkamp C, Wevers A, Geisel J, Sebok B, Bange FC, et al. Upregulation of keratin 17 expression in human HaCaT keratinocytes by interferon-gamma. The Journal of investigative dermatology. 1995;104(1):58-61.

82. Komine $\mathrm{M}$, Freedberg IM, Blumenberg M. Regulation of epidermal expression of keratin K17 in inflammatory skin diseases. The Journal of 
investigative dermatology. 1996;107(4):569-75.

\section{Ishida $\mathrm{Y}$, Kondo $\mathrm{T}$,} Takayasu T, Iwakura Y, Mukaida N. The essential involvement of crosstalk between IFN-gamma and TGFbeta in the skin wound-healing process. Journal of immunology. 2004;172(3):1848-55.

84 Jiang CK, Tomic-Canic

$M$, Lucas DJ, Simon M, Blumenberg $M$. TGF beta promotes the basal phenotype of epidermal keratinocytes: transcriptional induction of $\mathrm{K} \# 5$ and $\mathrm{K} \# 14$ keratin genes. Growth Factors. 1995;12(2):87-97.

85. Wang G, Higgins PJ, Gannon M, Staiano-Coico L. Transforming growth factor-beta 1 acts cooperatively with sodium $n$ butyrate to induce differentiation of normal human keratinocytes. Experimental cell research. 1992;198(1):27-30.

86. Mansbridge JN, Hanawalt PC. Role of transforming growth factor beta in the maturation of human epidermal keratinocytes. The Journal of investigative dermatology. 1988;90(3):336-41.

87. Desmouliere A, Redard M, Darby I, Gabbiani G. Apoptosis mediates the decrease in cellularity during the transition between granulation tissue and scar. The American journal of pathology. 1995;146(1):56-66.
88. Greenhalgh DG. The role of apoptosis in wound healing. The international journal of biochemistry \& cell biology. 1998;30(9):1019-30.

89. Profyris C, Tziotzios

C, Do Vale I. Cutaneous scarring: Pathophysiology, molecular mechanisms, and scar reduction therapeutics Part I. The molecular basis of scar formation. J Am Acad Dermatol.66(1):1-10; quiz 1-2.

90.

Kohan M, Muro AF, White ES, Berkman N. EDAcontaining cellular fibronectin induces fibroblast differentiation through binding to alpha4beta7 integrin receptor and MAPK/Erk 1/2-dependent signaling. FASEB journal : official publication of the Federation of American Societies for Experimental Biology. 2010;24(11):4503-12.

\section{$91 . \quad$ Desmouliere A,} Chaponnier C, Gabbiani G. Tissue repair, contraction, and the myofibroblast. Wound repair and regeneration : official publication of the Wound Healing Society [and] the European Tissue Repair Society. 2005;13(1):7-12.

\section{$92 . \quad$ Desmouliere A.}

Factors influencing myofibroblast differentiation during wound healing and fibrosis. Cell biology international. 1995;19(5):471-6. 93. Lu L, Saulis AS, Liu WR, Roy NK, Chao JD, Ledbetter S, et al. The temporal effects of anti- 
TGF-beta1, 2, and 3 monoclonal antibody on wound healing and hypertrophic scar formation. Journal of the American College of Surgeons. 2005;201(3):391-7.

94. Liu W, Cai Z, Wang D, Wu X, Cui L, Shang Q, et al. Blocking transforming growth factor-beta receptor signaling down-regulates transforming growth factor-beta1 autoproduction in keloid fibroblasts. Chinese journal of traumatology = Zhonghua chuang shang za zhi / Chinese Medical Association. 2002;5(2):77-81.

95. Bayat A, McGrouther DA, Ferguson MW. Skin scarring. Bmj. 2003;326(7380):88-92.

96. Ehrlich HP, Desmouliere A, Diegelmann RF, Cohen IK, Compton CC, Garner WL, et al. Morphological and immunochemical differences between keloid and hypertrophic scar. The American journal of pathology. 1994;145(1):105-13.

\section{$97 . \quad$ Phillips TJ. Chronic} cutaneous ulcers: etiology and epidemiology. The Journal of investigative dermatology. 1994;102(6):38S-41S.

98. Sen CK, Gordillo GM, Roy S, Kirsner R, Lambert L, Hunt TK, et al. Human skin wounds: a major and snowballing threat to public health and the economy. Wound repair and regeneration : official publication of the Wound Healing Society [and] the European
Tissue Repair Society. 2009;17(6):763-71.

$99 . \quad$ Ruckley CV.

Socioeconomic impact of chronic venous insufficiency and leg ulcers. Angiology. 1997;48(1):67-9. $100 . \quad$ Oien RF, Hakansson A, Ovhed I, Hansen BU. Wound management for 287 patients with chronic leg ulcers demands 12 fulltime nurses. Leg ulcer epidemiology and care in a well-defined population in southern Sweden. Scand J Prim Health Care. 2000;18(4):220-5.

101. Ebbeskog B, Lindholm C, Ohman S. Leg and foot ulcer patients. Epidemiology and nursing care in an urban population in south Stockholm, Sweden. Scand J Prim Health Care. 1996;14(4):23843.

$102 . \quad$ Oot-Giromini BA. Pressure ulcer prevalence, incidence and associated risk factors in the community. Decubitus. 1993;6(5):24-32. 103. Abbade LP, Lastoria

S. Venous ulcer: epidemiology, physiopathology, diagnosis and treatment. International journal of dermatology. 2005;44(6):449-56.

$104 . \quad H i c k s$ CW, Selvarajah

$\mathrm{S}$, Mathioudakis N, Perler BA, Freischlag JA, Black JH, 3rd, et al. Trends and determinants of costs associated with the inpatient care of diabetic foot ulcers. Journal of 
vascular surgery. 2014;60(5):124754, 54 e1-2.

105. Chin MS, Freniere BB, Bonney CF, Lancerotto L, Saleeby $\mathrm{JH}$, Lo YC, et al. Skin perfusion and oxygenation changes in radiation fibrosis. Plastic and reconstructive surgery. 2013;131(4):707-16.

$106 . \quad$ Bergan JJ, Schmid-

Schonbein GW, Coleridge Smith PD, Nicolaides AN, Boisseau MR, Eklof B. Chronic venous disease. Minerva cardioangiologica. 2007;55(4):45976.
107.
Clyne CA, Ramsden

WH, Chant AD, Webster JH. Oxygen tension on the skin of the gaiter area of limbs with venous disease. The British journal of surgery. 1985;72(8):644-7.

108. Coleridge Smith PD, Thomas P, Scurr JH, Dormandy JA. Causes of venous ulceration: a new hypothesis. British medical journal. 1988;296(6638):1726-7.

109. Gould L, Abadir P, Brem H, Carter M, Conner-Kerr T, Davidson J, et al. Chronic wound repair and healing in older adults: current status and future research. Wound repair and regeneration : official publication of the Wound Healing Society [and] the European Tissue Repair Society. 2014;23(1):113.

110. Kim BC, Kim HT, Park $\mathrm{SH}$, Cha JS, Yufit T, Kim SJ, et al. Fibroblasts from chronic wounds show altered TGF-beta-signaling and decreased TGF-beta Type II receptor expression. Journal of cellular physiology. 2003;195(3):331-6.

111. Eming SA, Martin P, Tomic-Canic M. Wound repair and regeneration: mechanisms, signaling, and translation. Sci Transl Med.6(265):265sr6.

$112 . \quad$ Tarnuzzer RW, Schultz GS. Biochemical analysis of acute and chronic wound environments. Wound repair and regeneration : official publication of the Wound Healing Society [and] the European Tissue Repair Society. 1996;4(3):321-5.

113. Qian LW, Fourcaudot AB, Yamane K, You T, Chan RK, Leung KP. Exacerbated and prolonged inflammation impairs wound healing and increases scarring. Wound repair and regeneration : official publication of the Wound Healing Society [and] the European Tissue Repair Society. 2015.

$114 . \quad B l a c k$ SB. Venous stasis ulcers: a review. Ostomy Wound Manage. 1995;41(8):20-2, 4-6, 8-30 passim.

$115 . \quad$ Olin JW, Beusterien KM, Childs MB, Seavey C, McHugh L, Griffiths RI. Medical costs of treating venous stasis ulcers: evidence from a retrospective cohort study. Vasc Med. 1999;4(1):1-7. 
116.

Rosique RG, Rosique

MJ, Farina Junior JA. Curbing

Inflammation in Skin Wound

Healing: A Review. Int J Inflam.

2015;2015:316235.

$117 . \quad$ Pastar I, Nusbaum

AG, Gil J, Patel SB, Chen J, Valdes J, et al. Interactions of methicillin resistant Staphylococcus aureus USA300 and Pseudomonas aeruginosa in polymicrobial wound infection. PloS one. 2013;8(2):e56846.

$118 . \quad$ Saarialho-Kere UK.

Patterns of matrix metalloproteinase and TIMP expression in chronic ulcers. Archives for dermatological research $=$ Archiv fur dermatologische Forschung. 1998;290 Suppl:S47-54.

119. Ferguson MW, Herrick SE, Spencer MJ, Shaw JE, Boulton AJ, Sloan P. The histology of diabetic foot ulcers. Diabetic medicine : a journal of the British Diabetic Association. 1996;13 Suppl 1:S30-3.

\section{Cho CY, Lo JS.}

Dressing the part. Dermatol Clin. 1998;16(1):25-47.

\section{$121 . \quad$ Leaper D, Assadian}

$\mathrm{O}$, Edmiston CE. Approach to chronic wound infections. $\mathrm{Br} J$

Dermatol. 2015;173(2):351-8.

\section{$122 . \quad$ Fonder MA, Lazarus}

GS, Cowan DA, Aronson-Cook B, Kohli AR, Mamelak AJ. Treating the chronic wound: A practical approach to the care of nonhealing wounds and wound care dressings. Journal of the American Academy of Dermatology. 2008;58(2):185206.

123. Junker JP, Kamel RA, Caterson EJ, Eriksson E. Clinical Impact Upon Wound Healing and Inflammation in Moist, Wet, and Dry Environments. Advances in wound care.2(7):348-56.

$124 . \quad$ Winter GD.

Formation of the scab and the rate of epithelization of superficial wounds in the skin of the young domestic pig. Nature. 1962;193:293-4.

$125 . \quad$ Field FK, Kerstein MD. Overview of wound healing in a moist environment. Am J Surg. 1994;167(1A):2S-6S.

126. Morin RJ, Tomaselli

NL. Interactive dressings and topical agents. Clinics in plastic surgery. 2007;34(4):643-58.

\section{$127 . \quad B a r n e a Y$, Amir A,}

Leshem D, Zaretski A, Weiss J, Shafir $\mathrm{R}$, et al. Clinical comparative study of aquacel and paraffin gauze dressing for split-skin donor site treatment. Annals of plastic surgery. 2004;53(2):132-6.

$128 . \quad$ Spangler D, Rothenburger $\mathrm{S}$, Nguyen $\mathrm{K}$, Jampani $\mathrm{H}$, Weiss $\mathrm{S}$, Bhende $\mathrm{S}$. In vitro antimicrobial activity of oxidized regenerated cellulose against antibiotic-resistant microorganisms. 
Surgical infections. 2003;4(3):255-

62.

129. de Oliveira GV, Nunes TA, Magna LA, Cintra ML, Kitten GT, Zarpellon S, et al. Silicone versus nonsilicone gel dressings: a controlled trial. Dermatologic surgery : official publication for American Society for Dermatologic Surgery [et al]. 2001;27(8):721-6. 130. Meaume $S$, Vallet $D$, Morere MN, Teot L. Evaluation of a silver-releasing hydroalginate dressing in chronic wounds with signs of local infection. Journal of wound care. 2005;14(9):411-9. $131 . \quad$ Moura LI, Dias AM, Suesca E, Casadiegos S, Leal EC, Fontanilla MR, et al. Neurotensinloaded collagen dressings reduce inflammation and improve wound healing in diabetic mice. Biochimica et biophysica acta. 2014;1842(1):32-43.

\section{$132 . \quad T u m m a l a p a l l i \mathrm{M}$,} Berthet $\mathrm{M}$, Verrier B, Deopura BL, Alam MS, Gupta B. Composite Wound Dressings of Pectin and Gelatin with Aloe vera and Curcumin as Bioactive Agents. International journal of biological macromolecules. 2015.

$133 . \quad$ Wu J, Zheng $Y$, Wen $X$, Lin $Q$, Chen $X, W$ U Z. Silver nanoparticle/bacterial cellulose gel membranes for antibacterial wound dressing: investigation in vitro and in vivo. Biomedical materials. 2014;9(3):035005.
134. Sood A, Granick MS, Tomaselli NL. Wound Dressings and Comparative Effectiveness Data. Advances in wound care. 2014;3(8):511-29.

\section{$135 . \quad$ McHeik JN, Barrault}

C, Levard G, Morel F, Bernard FX, Lecron JC. Epidermal healing in burns: autologous keratinocyte transplantation as a standard procedure: update and perspective. Plast Reconstr Surg Glob Open.2(9):e218.

136.

NicholasE. O'Connora JM, Susan Banks-Schlegelb, Olaniyi Kehindeb, Howard Green. Grafting of burns with cultured epithelium prepared from autologous epidermal cells. Lancet. 1981;1(8211):75-8.

137. Gallico GG, 3rd, O'Connor NE, Compton CC, Kehinde $\mathrm{O}$, Green $\mathrm{H}$. Permanent coverage of large burn wounds with autologous cultured human epithelium. N Engl J Med. 1984;311(7):448-51.

\section{Grant I, Warwick K,} Marshall J, Green C, Martin R. The co-application of sprayed cultured autologous keratinocytes and autologous fibrin sealant in a porcine wound model. Br J Plast Surg. 2002;55(3):219-27.

\section{$139 . \quad$ Svensjo T, Yao F,} Pomahac B, Eriksson E. Autologous keratinocyte suspensions accelerate epidermal wound healing in pigs. J Surg Res. 2001;99(2):211-21. 
140.

Adams JC, Watt FM.

Changes in keratinocyte adhesion during terminal differentiation: reduction in fibronectin binding precedes alpha 5 beta 1 integrin loss from the cell surface. Cell. 1990;63(2):425-35.

141.

Langdon RC, Cuono

$\mathrm{CB}$, Birchall N, Madri JA, Kuklinska E, McGuire J, et al. Reconstitution of structure and cell function in human skin grafts derived from cryopreserved allogeneic dermis and autologous cultured keratinocytes. The Journal of investigative dermatology. 1988;91(5):478-85.

\section{$142 . \quad$ Williamson JS,} Snelling CF, Clugston $\mathrm{P}$, Macdonald IB, Germann E. Cultured epithelial autograft: five years of clinical experience with twenty-eight patients. J Trauma. 1995;39(2):30919.

143. Eweida AM, Marei

MK. Naturally Occurring Extracellular Matrix Scaffolds for Dermal Regeneration: Do They Really Need Cells? BioMed research international. 2015;2015:839694.

144. Huang SP, Hsu CC, Chang SC, Wang $\mathrm{CH}$, Deng SC, Dai $\mathrm{NT}$, et al. Adipose-derived stem cells seeded on acellular dermal matrix grafts enhance wound healing in a murine model of a fullthickness defect. Annals of plastic surgery. 2012;69(6):656-62.
145. Cam C, Zhu S, Truong

NF, Scumpia PO, Segura T. Systematic evaluation of natural scaffolds in cutaneous wound healing. Journal of materials chemistry $B$, Materials for biology and medicine. 2015;3(40):7986-92. $146 . \quad$ Wilkins LM, Watson SR, Prosky SJ, Meunier SF, Parenteau NL. Development of a bilayered living skin construct for clinical applications. Biotechnology and bioengineering. 1994;43(8):747-56.

$147 . \quad$ Bonassar LJ, Vacanti CA. Tissue engineering: the first decade and beyond. Journal of cellular biochemistry Supplement. 1998;30-31:297-303.

$148 . \quad$ Hollister SJ. Porous

scaffold design for tissue engineering. Nature materials. 2005;4(7):518-24.

149. Asti A, Gioglio L.

Natural and synthetic biodegradable polymers: different scaffolds for cell expansion and tissue formation. Int J Artif Organs. 2014;37(3):187-205.

150. Tanaka $\mathrm{H}$, Matsumura M, Veliky IA. Diffusion characteristics of substrates in Caalginate gel beads. Biotechnology and bioengineering. 1984;26(1):538.

151. Drury JL, Mooney DJ. Hydrogels for tissue engineering: scaffold design variables and 
applications. Biomaterials. 2003;24(24):4337-51.

$152 . \quad \mathrm{Li} \mathrm{RH}$, Altreuter DH, Gentile FT. Transport characterization of hydrogel matrices for cell encapsulation. Biotechnology and bioengineering. 1996;50(4):365-73.

$153 . \quad$ Valentin JE, Freytes

DO, Grasman JM, Pesyna C, Freund J, Gilbert TW, et al. Oxygen diffusivity of biologic and synthetic scaffold materials for tissue engineering. Journal of biomedical materials research Part A. 2009;91(4):1010-7.

$154 . \quad$ Kim BS, Nikolovski J, Bonadio J, Mooney DJ. Cyclic mechanical strain regulates the development of engineered smooth muscle tissue. Nat Biotechnol. 1999;17(10):979-83.

155.

Butler DL, Goldstein

SA, Guilak F. Functional tissue engineering: the role of biomechanics. J Biomech Eng. 2000;122(6):570-5.

$156 . \quad$ Cowin SC. How is a tissue built? J Biomech Eng. 2000;122(6):553-69.

\section{$157 . \quad$ Kamata H, Li X,}

Chung UI, Sakai T. Design of Hydrogels for Biomedical Applications. Advanced healthcare materials. 2015.

$158 . \quad$ Smetana K, Jr. Cell biology of hydrogels. Biomaterials. 1993;14(14):1046-50.
159. Zhong SP, Zhang YZ, Lim CT. Tissue scaffolds for skin wound healing and dermal reconstruction. Wiley Interdiscip Rev Nanomed Nanobiotechnol.2(5):510-25. 160. Badylak SF, Freytes DO, Gilbert TW. Extracellular matrix as a biological scaffold material: Structure and function. Acta biomaterialia. 2009;5(1):1-13. 161. Jansen LA, De Caigny $P$, Guay NA, Lineaweaver WC, Shokrollahi K. The evidence base for the acellular dermal matrix AlloDerm: a systematic review. Annals of plastic surgery. 2013;70(5):587-94.

162. Nathoo R, Howe N, Cohen G. Skin substitutes: an overview of the key players in wound management. J Clin Aesthet Dermatol.7(10):44-8.

163. Mansbridge J, Liu K, Patch R, Symons K, Pinney E. Threedimensional fibroblast culture implant for the treatment of diabetic foot ulcers: metabolic activity and therapeutic range. Tissue Eng. 1998;4(4):403-14. 164. Fitton AR, Drew $P$, Dickson WA. The use of a bilaminate artificial skin substitute (Integra) in acute resurfacing of burns: an early experience. $\mathrm{Br} J$ Plast Surg. 2001;54(3):208-12. 165. Trent JF, Kirsner RS. Tissue engineered skin: Apligraf, a bi-layered living skin equivalent. 
International journal of clinical practice. 1998;52(6):408-13.

166. Still J, Glat $P$, Silverstein P, Griswold J, Mozingo D. The use of a collagen sponge/living cell composite material to treat donor sites in burn patients. Burns. 2003;29(8):837-41.

$167 . \quad$ Gasperini L, Mano JF, Reis RL. Natural polymers for the microencapsulation of cells. J R Soc Interface. 2014;11(100):20140817. 168. Neumann PM, Zur B, Ehrenreich Y. Gelatin-based sprayable foam as a skin substitute. J Biomed Mater Res. 1981;15(1):918.

169. Nilsson K, Scheirer W, Merten OW, Ostberg L, Liehl E, Katinger HW, et al. Entrapment of animal cells for production of monoclonal antibodies and other biomolecules. Nature. 1983;302(5909):629-30.

$170 . \quad$ Reiter M, Hohenwarter O, Gaida T, Zach N, Schmatz C, Bluml G, et al. The use of macroporous gelatin carriers for the cultivation of mammalian cells in fluidised bed reactors.

Cytotechnology. 1990;3(3):271-7.

$171 . \quad$ Gustafson $\mathrm{CJ}$, Birgisson A, Junker J, Huss $F$, Salemark $L$, Johnson $H$, et al. Employing human keratinocytes cultured on macroporous gelatin spheres to treat full thicknesswounds: an in vivo study on athymic rats. Burns. 2007;33(6):726-35.

$172 . \quad$ Seland $\mathrm{H}$, Gustafson $\mathrm{CJ}$, Johnson $\mathrm{H}$, Junker JP, Kratz G. Transplantation of acellular dermis and keratinocytes cultured on porous biodegradable microcarriers into full-thickness skin injuries on athymic rats. Burns. 2010;37(1):99108.

173. Huss FR, Junker JP, Johnson H, Kratz G. Macroporous gelatine spheres as culture substrate, transplantation vehicle, and biodegradable scaffold for guided regeneration of soft tissues. In vivo study in nude mice. Journal of plastic, reconstructive \& aesthetic surgery : JPRAS. 2007;60(5):543-55.

$174 . \quad H u s s$ FR, Nyman E, Bolin JS, Kratz G. Use of macroporous gelatine spheres as a biodegradable scaffold for guided tissue regeneration of healthy dermis in humans: an in vivo study. Journal of plastic, reconstructive \& aesthetic surgery : JPRAS2010;63(5):848-57.

$175 . \quad$ Pettersson S, Wettero J, Tengvall P, Kratz G. Cell expansion of human articular chondrocytes on macroporous gelatine scaffolds-impact of microcarrier selection on cell proliferation. Biomedical materials. 2011;6(6):065001.

$176 . \quad$ Sommar $P$, Pettersson S, Ness C, Johnson H, 
Kratz G, Junker JP. Engineering three-dimensional cartilage- and bone-like tissues using human dermal fibroblasts and macroporous gelatine microcarriers. Journal of plastic, reconstructive $\&$ aesthetic surgery : JPRAS. 2009;63(6):1036-46.

$177 . \quad$ Nuutila K, Katayama

$\mathrm{S}$, Vuola J, Kankuri E. Human Wound-Healing Research: Issues and Perspectives for Studies Using Wide-Scale Analytic Platforms. Advances in wound care.3(3):26471.

$178 . \quad$ Richmond NA, Lamel SA, Davidson JM, Martins-Green M, Sen CK, Tomic-Canic M, et al. USNational Institutes of Health-funded research for cutaneous wounds in 2012. Wound repair and regeneration : official publication of the Wound Healing Society [and] the European Tissue Repair Society. 2013;21(6):789-92.

\section{$179 . \quad$ Lindblad WJ.}

Considerations for selecting the correct animal model for dermal wound-healing studies. J Biomater Sci Polym Ed. 2008;19(8):1087-96. 180. Liang CC, Park AY, Guan JL. In vitro scratch assay: a convenient and inexpensive method for analysis of cell migration in vitro. Nature protocols. 2007;2(2):329-33.

$181 . \quad$ Yarrow JC, Perlman ZE, Westwood NJ, Mitchison TJ. A high-throughput cell migration assay using scratch wound healing, a comparison of image-based readout methods. BMC Biotechnol. 2004;4:21.

182. Moulin V, Castilloux

G, Jean A, Garrel DR, Auger FA, Germain L. In vitro models to study wound healing fibroblasts. Burns. 1996;22(5):359-62.

183. Hull BE, Sher SE, Rosen S, Church D, Bell E. Fibroblasts in isogeneic skin equivalents persist for long periods after grafting. The Journal of investigative dermatology. 1983;81(5):436-8.

184. Sriram G, Bigliardi PL, Bigliardi-Qi M. Fibroblast heterogeneity and its implications for engineering organotypic skin models in vitro. European journal of cell biology. 2015;94(11):483-512.

185.

Cooper L, Johnson C, Burslem F, Martin P. Wound healing and inflammation genes revealed by array analysis of 'macrophageless' PU.1 null mice. Genome Biol. 2005;6(1):R5.

186.

Grose R, Werner S.

Wound-healing studies in transgenic and knockout mice. Molecular biotechnology. 2004;28(2):147-66.

$187 . \quad$ Sato H, Ebisawa K, Takanari K, Yagi S, Toriyama K, Yamawaki-Ogata A, et al. Skinderived precursor cells promote wound healing in diabetic mice. 
Annals of plastic surgery.

2014;74(1):114-20.

188. Shu B, Xie JL, Xu YB,

Lai W, Huang $Y$, Mao RX, et al.

Effects of skin-derived precursors on wound healing of denervated skin in a nude mouse model. Int J Clin Exp Pathol. 2015;8(3):2660-9.

189.

Dorsett-Martin WA.

Rat models of skin wound healing: a review. Wound repair and regeneration : official publication of the Wound Healing Society [and] the European Tissue Repair Society. 2004;12(6):591-9.

190. Galiano RD, Michaels

Jt, Dobryansky M, Levine JP, Gurtner GC. Quantitative and reproducible murine model of excisional wound healing. Wound repair and regeneration : official publication of the Wound Healing Society [and] the European Tissue Repair Society. 2004;12(4):485-92. 191. Wong VW, Sorkin M, Glotzbach JP, Longaker MT, Gurtner GC. Surgical approaches to create murine models of human wound healing. J Biomed Biotechnol. 2010;2011:969618.

192. Sullivan TP, Eaglstein WH, Davis SC, Mertz P. The pig as a model for human wound healing. Wound repair and regeneration: official publication of the Wound Healing Society [and] the European Tissue Repair Society. 2001;9(2):6676.
193. Gordillo GM,

Bernatchez SF, Diegelmann R, Di Pietro LA, Eriksson E, Hinz B, et al. Preclinical Models of Wound Healing: Is Man the Model? Proceedings of the Wound Healing Society Symposium. Advances in wound care. 2013;2(1):1-4.

194. Ansell DM, Holden KA, Hardman MJ. Animal models of wound repair: Are they cutting it? Experimental dermatology. 2012;21(8):581-5.

195. Brown GL, Nanney

LB, Griffen J, Cramer AB, Yancey JM, Curtsinger $\mathrm{LJ}, 3 \mathrm{rd}$, et al.

Enhancement of wound healing by topical treatment with epidermal growth factor. N Engl J Med. 1989;321(2):76-9.

196.

Lindstedt $\mathrm{E}$,

Sandblom P. Wound healing in man: tensile strength of healing wounds in some patient groups. Ann Surg. 1975;181(6):842-6. 197. Robinson MK, Perkins MA, Basketter DA. Application of a 4-h human patch test method for comparative and investigative assessment of skin irritation. Contact Dermatitis. 1998;38(4):194-202.

198 McNamee PM, Api AM, Basketter DA, Frank Gerberick G, Gilpin DA, Hall BM, et al. A review of critical factors in the conduct and interpretation of the human repeat insult patch test. 
Regul Toxicol Pharmacol.

2008;52(1):24-34 .

$199 . \quad$ Wilhelmus KR. The

Draize eye test. Surv Ophthalmol. 2001;45(6):493-515.

200.

Kratz G. Modeling of

wound healing processes in human

skin using tissue culture.

Microscopy research and

technique. 1998;42(5):345-50.

201. Schultz GS, Davidson

JM, Kirsner RS, Bornstein P, Herman

IM. Dynamic reciprocity in the wound microenvironment. Wound repair and regeneration : official publication of the Wound Healing Society [and] the European Tissue Repair Society. 2011;19(2):134-48. $202 . \quad$ Raghow $R$. The role of extracellular matrix in postinflammatory wound healing and fibrosis. FASEB journal : official publication of the Federation of American Societies for Experimental Biology. 1994;8(11):823-31.

$203 . \quad$ Olczyk P, Mencner L, Komosinska-Vassev K. The role of the extracellular matrix components in cutaneous wound healing. BioMed research international. 2014;2014:747584. $204 . \quad B r o w n$ EJ, Goodwin

$\mathrm{JL}$. Fibronectin receptors of phagocytes. Characterization of the Arg-Gly-Asp binding proteins of human monocytes and polymorphonuclear leukocytes. J Exp Med. 1988;167(3):777-93.
205. Haskill S, Johnson C, Eierman D, Becker S, Warren K. Adherence induces selective mRNA expression of monocyte mediators and proto-oncogenes. Journal of immunology. 1988;140(5):1690-4. 206.

Discher DE, Janmey

$P$, Wang YL. Tissue cells feel and respond to the stiffness of their substrate. Science.

2005;310(5751):1139-43.

207.

Bornstein P, Sage EH. Matricellular proteins: extracellular modulators of cell function. Current opinion in cell biology. 2002;14(5):608-16.

208.

Ruoslahti E. Integrin signaling and matrix assembly. Tumour Biol. 1996;17(2):117-24. 209.

Mitra SK, Hanson DA, Schlaepfer DD. Focal adhesion kinase: in command and control of cell motility. Nature reviews Molecular cell biology. 2005;6(1):56-68.

$210 . \quad H a n g ~ Q$, Isaji $T$, Hou

S, Im S, Fukuda T, Gu J. Integrin alpha5 suppresses the phosphorylation of epidermal growth factor receptor and its cellular signaling of cell proliferation via $\mathrm{N}$-glycosylation. The Journal of biological chemistry. 2015.

211. Eckes B, Nischt R, Krieg T. Cell-matrix interactions in dermal repair and scarring. Fibrogenesis \& tissue repair. 2010;3:4. 
212. Kuwada SK, Li X. Integrin alpha5/beta1 mediates fibronectin-dependent epithelial cell proliferation through epidermal growth factor receptor activation. Molecular biology of the cell. 2000;11(7):2485-96.

213.

Lin $F$, Ren XD, Pan Z,

Macri L, Zong WX, Tonnesen MG, et al. Fibronectin growth factorbinding domains are required for fibroblast survival. The Journal of investigative dermatology.

2011;131(1):84-98.

214.

Smithmyer ME,

Sawicki LA, Kloxin AM. Hydrogel scaffolds as in vitro models to study fibroblast activation in wound healing and disease. Biomaterials science. 2014;2(5):634-50.

\section{Hinz B, Mastrangelo}

D, Iselin CE, Chaponnier C, Gabbiani

$G$. Mechanical tension controls granulation tissue contractile activity and myofibroblast differentiation. The American journal of pathology. 2001;159(3):1009-20.

216.

Desmouliere A,

Geinoz A, Gabbiani F, Gabbiani G. Transforming growth factor-beta 1 induces alpha-smooth muscle actin expression in granulation tissue myofibroblasts and in quiescent and growing cultured fibroblasts. The Journal of cell biology. 1993;122(1):103-11.
217.
Shephard P, Martin
G, Smola-Hess S, Brunner G, Krieg T,

Smola H. Myofibroblast

differentiation is induced in keratinocyte-fibroblast co-cultures and is antagonistically regulated by endogenous transforming growth factor-beta and interleukin-1. The American journal of pathology. 2004;164(6):2055-66.

$218 . \quad W e r n e r S$, Krieg $\mathrm{T}$, Smola H. Keratinocyte-fibroblast interactions in wound healing. The Journal of investigative dermatology. 2007;127(5):9981008.

$219 . \quad$ Rheinwald JG, Green

$H$. Serial cultivation of strains of human epidermal keratinocytes: the formation of keratinizing colonies from single cells. Cell. 1975;6(3):331-43.

$220 . \quad$ Smola $\mathrm{H}$, Thiekotter $\mathrm{G}$, Fusenig NE. Mutual induction of growth factor gene expression by epidermal-dermal cell interaction. The Journal of cell biology. 1993;122(2):417-29.

221. Waelti ER, Inaebnit SP, Rast HP, Hunziker T, Limat A, Braathen LR, et al. Co-culture of human keratinocytes on postmitotic human dermal fibroblast feeder cells: production of large amounts of interleukin 6 . The Journal of investigative dermatology. 1992;98(5):805-8.

222.

Brauchle $\mathrm{M}$, Angermeyer K, Hubner G, Werner S. Large induction of keratinocyte growth factor expression by serum 
growth factors and pro-

inflammatory cytokines in cultured fibroblasts. Oncogene. 1994;9(11):3199-204.

$223 . \quad H u a n g P, B i J$, Owen GR, Chen W, Rokka A, Koivisto L, et al. Keratinocyte Microvesicles Regulate the Expression of Multiple Genes in Dermal Fibroblasts. The Journal of investigative dermatology. 2015;135(12):3051-9. 224. Gupta P, Ismadi MZ, Verma PJ, Fouras A, Jadhav S, Bellare J, et al. Optimization of agitation speed in spinner flask for microcarrier structural integrity and expansion of induced pluripotent stem cells. Cytotechnology. 2014.

225.

Dusting J, Sheridan J,

Hourigan K. A fluid dynamics approach to bioreactor design for cell and tissue culture.

Biotechnology and bioengineering. 2006;94(6):1196-208.

$226 . \quad$ Croughan MS, Hamel JF, Wang DI. Hydrodynamic effects on animal cells grown in microcarrier cultures. 1987. Biotechnology and bioengineering. 2006;95(2):295-305.

\section{$227 . \quad$ Cherry RS,}

Papoutsakis ET. Physical

mechanisms of cell damage in microcarrier cell culture bioreactors. Biotechnology and bioengineering. 1988;32(8):100114.
228.
Mosmann T. Rapid

colorimetric assay for cellular growth and survival: application to proliferation and cytotoxicity assays. Journal of immunological methods. 1983;65(1-2):55-63. $229 . \quad$ Tomasz M. Mitomycin C: small, fast and deadly (but very selective). Chemistry \& biology. 1995;2(9):575-9.

$230 . \quad$ Schindelin J, Arganda-Carreras I, Frise E, Kaynig $\mathrm{V}$, Longair M, Pietzsch T, et al. Fiji: an open-source platform for biological-image analysis. Nature methods. 2012;9(7):676-82.

$231 . \quad H e i d$ CA, Stevens J, Livak KJ, Williams PM. Real time quantitative PCR. Genome research. 1996;6(10):986-94.

232.

Chien A, Edgar DB, Trela JM. Deoxyribonucleic acid polymerase from the extreme thermophile Thermus aquaticus. Journal of bacteriology. 1976;127(3):1550-7.

$233 . \quad$ Saiki RK, Gelfand DH, Stoffel S, Scharf SJ, Higuchi R, Horn $\mathrm{GT}$, et al. Primer-directed enzymatic amplification of DNA with a thermostable DNA polymerase. Science. 1988;239(4839):487-91.

234.

Livak KJ, Schmittgen

TD. Analysis of relative gene expression data using real-time quantitative PCR and the 2(-Delta Delta $C(T))$ Method. Methods. 2001;25(4):402-8.

$235 . \quad$ S. Kim Suvarna CL, John D. Bancoft. Bancroft's theory 
and practice of histological techniques. 7th ed: Churchill Livingstone Elsevier; 2013.

236.

Cid Mouteira P,

Ortiz-Rey JA, Gomez de Maria C, San Miguel Fraile P, Albor Barroso

$A$, Regueiro Parcero B, et al. [Expression of cytokeratin 5 and calretinin in clear-cell renal cell carcinoma]. Actas urologicas espanolas. 2006;30(4):367-71.

$237 . \quad$ Carpenter PM, Wang-Rodriguez J, Chan OT, Wilczynski SP. Laminin 5 expression in metaplastic breast carcinomas. The American journal of surgical pathology. 2008;32(3):345-53.

238. Hayden PJ, Petrali JP, Stolper G, Hamilton TA, Jackson GR, Jr., Wertz PW, et al. Microvesicating effects of sulfur mustard on an in vitro human skin model. Toxicology in vitro : an international journal published in association with BIBRA. 2009;23(7):1396-405.

239.

Rittie L, Varani J,

Kang S, Voorhees JJ, Fisher GJ.

Retinoid-induced epidermal hyperplasia is mediated by epidermal growth factor receptor activation via specific induction of its ligands heparin-binding EGF and amphiregulin in human skin in vivo. The Journal of investigative dermatology. 2006;126(4):732-9.

240. Lersch R, Stellmach

V, Stocks C, Giudice G, Fuchs E. Isolation, sequence, and expression of a human keratin $\mathrm{K} 5$ gene: transcriptional regulation of keratins and insights into pairwise control. Molecular and cellular biology. 1989;9(9):3685-97. $241 . \quad$ Koch PJ, Roop DR. The role of keratins in epidermal development and homeostasis-going beyond the obvious. The Journal of investigative dermatology. 2004;123(5):x-xi.

$242 . \quad$ Paramio JM, Casanova ML, Segrelles C, Mittnacht S, Lane EB, Jorcano JL. Modulation of cell proliferation by cytokeratins K10 and K16. Molecular and cellular biology. 1999;19(4):3086-94.

$243 . \quad$ Gerdes J, Lemke $H$, Baisch H, Wacker HH, Schwab U, Stein $\mathrm{H}$. Cell cycle analysis of a cell proliferation-associated human nuclear antigen defined by the monoclonal antibody Ki-67. Journal of immunology. 1984;133(4):17105.

244. Quah BJ, Warren HS, Parish CR. Monitoring lymphocyte proliferation in vitro and in vivo with the intracellular fluorescent dye carboxyfluorescein diacetate succinimidyl ester. Nature protocols. 2007;2(9):2049-56. $245 . \quad H e g d e$ S, Raghavan S. A skin-depth analysis of integrins: role of the integrin network in health and disease. Cell communication \& adhesion. 2013;20(6):155-69. 
246.

Williams DF. The

biomaterials conundrum in tissue engineering. Tissue engineering Part A. 2014;20(7-8):1129-31. 247. Meigel WN, Gay S, Weber L. Dermal architecture and collagen type distribution. Archives for dermatological research = Archiv fur dermatologische Forschung. 1977;259(1):1-10. 248. Parish CR.

Fluorescent dyes for lymphocyte migration and proliferation studies. Immunology and cell biology. 1999;77(6):499-508.

249.

Last'ovicka J,

Budinsky V, Spisek R, Bartunkova J. Assessment of lymphocyte proliferation: CFSE kills dividing cells and modulates expression of activation markers. Cellular immunology. 2009;256(1-2):79-85. 250. Xu WL, Li SL, Wen M, Wen JY, Han J, Zhang HZ, et al. Tracking in vivo migration and distribution of antigen-specific cytotoxic T lymphocytes by 5,6carboxyfluorescein diacetate succinimidyl ester staining during cancer immunotherapy. Chinese medical journal.

2013;126(16):3019-25.

251. Jbeily N, Claus RA, Dahlke K, Neugebauer U, Bauer M, Gonnert FA. Comparative suitability of CFDA-SE and rhodamine $6 \mathrm{G}$ for in vivo assessment of leukocyteendothelium interactions. Journal of biophotonics. 2014;7(6):369-75.
252. Fujioka $\mathrm{H}$, Hunt PJ, Rozga J, Wu GD, Cramer DV, Demetriou AA, et al. Carboxyfluorescein (CFSE) labelling of hepatocytes for short-term localization following intraportal transplantation. Cell transplantation. 1994;3(5):397-408. 253.

Diana $\mathrm{M}$, Robinet $\mathrm{E}$, Liu YY, Legner A, Kong SH, Schiraldi $L$, et al. Confocal Imaging and Tissue-Specific Fluorescent Probes for Real-Time In Vivo Immunohistochemistry. Proof of the Concept in a Gastric Lymph Node Metastasis Model. Annals of surgical oncology. 2015.

254 Quah BJ, Parish CR. New and improved methods for measuring lymphocyte proliferation in vitro and in vivo using CFSE-like fluorescent dyes. Journal of immunological methods. 2012;379(1-2):1-14.

255. Hess CL, Howard MA, Attinger CE. A review of mechanical adjuncts in wound healing: hydrotherapy, ultrasound, negative pressure therapy, hyperbaric oxygen, and electrostimulation. Annals of plastic surgery. 2003;51(2):210-8.

256.

Schneider LA, Korber

A, Grabbe S, Dissemond J. Influence of $\mathrm{pH}$ on wound-healing: a new perspective for wound-therapy? Archives for dermatological research $=$ Archiv fur 
dermatologische Forschung. 2007;298(9):413-20.

$257 . \quad$ Dumville JC, Land L, Evans D, Peinemann F. Negative pressure wound therapy for treating leg ulcers. The Cochrane database of systematic reviews. 2015;7:CD011354.

258.

Schreml S, Szeimies RM, Karrer S, Heinlin J, Landthaler $\mathrm{M}$, Babilas $\mathrm{P}$. The impact of the $\mathrm{pH}$ value on skin integrity and cutaneous wound healing. Journal of the European Academy of Dermatology and Venereology : JEADV. 2010;24(4):373-8.

$259 . \quad$ Muller $M$, Trocme $C$, Lardy B, Morel F, Halimi S, Benhamou PY. Matrix metalloproteinases and diabetic foot ulcers: the ratio of MMP-1 to TIMP-1 is a predictor of wound healing. Diabetic medicine : a journal of the British Diabetic Association. 2008;25(4):419-26. $260 . \quad$ Didelot $C$, Schmitt $E$, Brunet $M$, Maingret L, Parcellier A, Garrido C. Heat shock proteins: endogenous modulators of apoptotic cell death. Handbook of experimental pharmacology. 2006(172):171-98.

261. Larsen M, Tremblay ML, Yamada KM. Phosphatases in cell-matrix adhesion and migration. Nature reviews Molecular cell biology. 2003;4(9):700-11.

\section{$262 . \quad H y t o n e n$ VP, Wehrle-}

Haller B. Mechanosensing in cell- matrix adhesions - Converting tension into chemical signals. Experimental cell research. 2015.

$263 . \quad$ Sieg DJ, Hauck CR, llic $D$, Klingbeil CK, Schaefer E, Damsky $\mathrm{CH}$, et al. FAK integrates growthfactor and integrin signals to promote cell migration. Nature cell biology. 2000;2(5):249-56.

$264 . \quad B u l l e n \mathrm{EC}$, Longaker MT, Updike DL, Benton R, Ladin D, Hou Z, et al. Tissue inhibitor of metalloproteinases- 1 is decreased and activated gelatinases are increased in chronic wounds. The Journal of investigative dermatology. 1995;104(2):236-40. $265 . \quad$ Gibbs S. In vitro irritation models and immune reactions. Skin pharmacology and physiology. 2009;22(2):103-13. 266. Netzlaff F, Lehr CM, Wertz PW, Schaefer UF. The human epidermis models EpiSkin, SkinEthic and EpiDerm: an evaluation of morphology and their suitability for testing phototoxicity, irritancy, corrosivity, and substance transport. European journal of pharmaceutics and biopharmaceutics : official journal of Arbeitsgemeinschaft fur Pharmazeutische Verfahrenstechnik eV. 2005;60(2):167-78.

267. Fentem JH, Briggs $D$, Chesne C, Elliott GR, Harbell JW, Heylings JR, et al. A prevalidation study on in vitro tests for acute skin irritation. results and evaluation by 
the Management Team. Toxicology

in vitro : an international journal

published in association with BIBRA.

2001;15(1):57-93.

268.

Jansson $\mathrm{K}$, Kratz $\mathrm{G}$,

Haegerstrand $A$. Characterization of a new in vitro model for studies of reepithelialization in human partial thickness wounds. In vitro cellular \& developmental biology Animal. 1996;32(9):534-40.

$269 . \quad$ Welss T, Basketter DA, Schroder KR. In vitro skin irritation: facts and future. State of the art review of mechanisms and models. Toxicology in vitro : an international journal published in association with BIBRA. 2004;18(3):231-43. 


\section{Papers}

The articles associated with this thesis have been removed for copyright reasons. For more details about these see:

http://urn.kb.se/resolve?urn=urn:nbn:se:liu:diva-123313 